
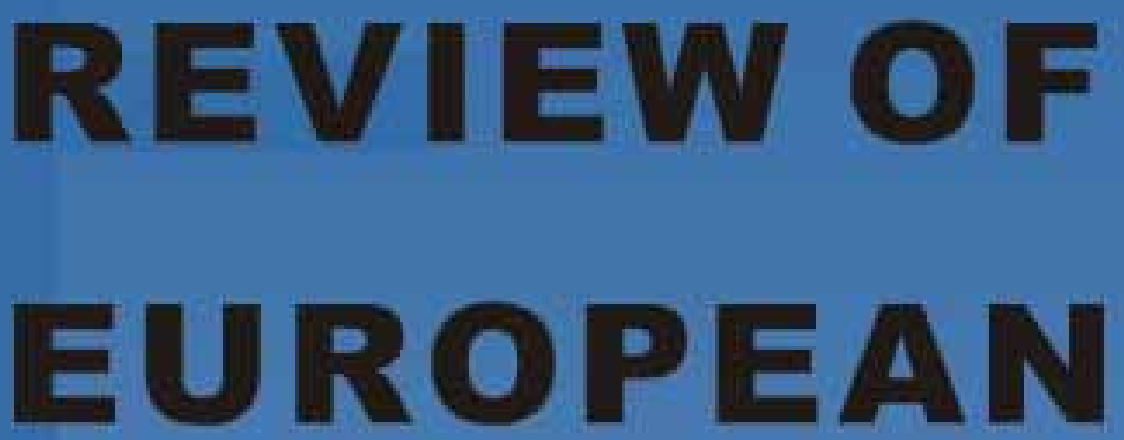

STUDIES

Vol. 1, No. 1

June 2009

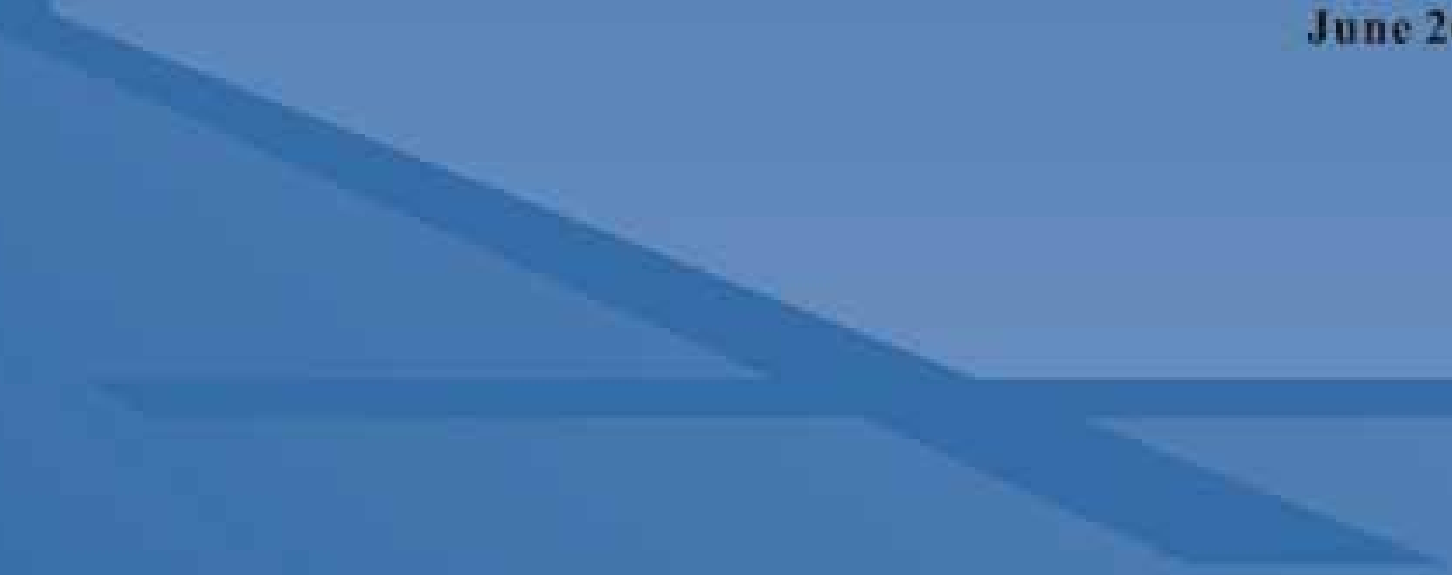

CCSE

Canadian Center of Science and Education 


\section{Editorial Board}

Alexandros Kyrtsis University of Athens, Greece

Jenny Zhang Canadian Center of Science and Education, Canada

Sathya Swaroop Debasish Fakir Mohan University, India

Wenwu Zhao Macrothink Institute, USA

Ying Jin Qingdao Technological University, China 


\section{Review of European Studies}

Vol. 1, No. 1

\section{Contents}

European Lifelong Learning Educational Policy in the Light of the "Lisbon Agenda": The Greek Case

Eugenia Panitsidou \& Adamantios Papastamatis

The Impacts of British Policies and the IRA's Ideology on the 1981 Irish Hunger Strike

Lu Yan

Maintaining the Standard Ukrainian Language: A Challenge for Teachers in Australia

Halyna Koscharsky \& Geoffrey Hull

The Theoretical Quandary of Subjectivity: An Intellectual Historical Note on the Action Theories of Talcott

Parsons and Alfred Schutz

Matthew M. Chew

Comparison of the Convertible Bond Market Development in China and Europe and the Enlightenment

Shengchun Zhu

Chôra: Tracing the Presence

Nicoletta Isar

Perspective on Natural Gas Crisis between Russia and Ukraine

Chunyang Shi

Voice of Turkish Customer: Importance of Expectations and Level of Satisfaction at Airport Facilities

Özlem Atalı 


\title{
European Lifelong Learning Educational Policy in the Light of the "Lisbon Agenda": The Greek Case
}

Eugenia Panitsidou (Corresponding author)

$\mathrm{PhD}$ Candidate, University of Macedonia

156 Egnatias St. 54006 Thessaloniki, Greece

Tel: 30-2310-420304Ｅ-mail: epantsidou@uom.gr

Adamantios Papastamatis

Assistant Professor, University of Macedonia

156 Egnatias St. 54006 Thessaloniki, Greece

Tel: 30-2310-891324Ｅ-mail: papastam@uom.gr

\begin{abstract}
Investment in human capital emerged as core priority for European Union (EU) policies at the Lisbon European Council of 23 and 24 March 2000, shifting the perspective as regards the correlation between economic and social capital, and providing for strategic goals in order to strengthen employment, economic reform and social cohesion. Hence, novel priorities have emerged for Greek educational policy, accrediting exceptional significance to lifelong learning so as to raise compatibility with the "knowledge based society" mandates. The present paper attempts a policy impact analysis through thorough review of Greek education and training policies undertaken to respond to the European challenges. In the light of the evolving Lisbon agenda, it takes account of the legal context and underlying principles of Greek educational policy with respect to lifelong learning, to draw upon the impact of an EU convergence policy activating educational initiatives and objectives to attain sustainable growth development.
\end{abstract}

Keywords: Lifelong Learning, European Union, Lisbon agenda, Greek educational policy

\section{Introduction}

Contemporary European societies lead under the impact of socioeconomic internationalization, digital technology advancement as well as demographic reallocation (Giddens 1990, Kumar 2005). Problems faced by the European Union (EU), such as competitiveness deficiency and unemployment rise, call for reforms able to reinforce economic effectiveness, promote excellence in knowledge and technology, and enhance social cohesion. Moreover, EU enlargement and emerging of new competitors (e.g. China and India) intensify the urgency for immediate action. In this context, lifelong education is considered conditio sine qua non for the attainment of EU objectives, through a functional approach of education for human resources development and unemployment compression (De la Fuente and Ciccone 2002, OECD 2003, Psacharopoulos and Patrinos 2002). Nevertheless, at the same time Lifelong Learning (LL) comprises a "platonic" dimension, expecting to facilitate European citizens' access to institutions and participation in democracy, and strengthen social cohesion (Feinstein and Sabbates 2008, Longworth 2006, Murphy 2003, Pearce 2000, UNESCO 1976, Vandamme 2000). 
Thus, investment in human capital emerged as core priority for EU policies at the Lisbon European Council, denoting the aim "to become the most competitive and dynamic knowledge-based economy in the world, capable of sustainable economic growth" and providing for strategic goals to strengthen employment, economic reform and social cohesion, referred to as the "Lisbon agenda" (European Council 2000).

The Lisbon agenda led to a common policy project, introducing a schema of enhanced collaboration in education and training among member states, committing them to a consistent strategy and concrete objectives, and accentuating the key role of adult education systems, so as to provide equal opportunities for all European citizens to participate in the "knowledge-led society". By means of the "open method of coordination" greater convergence towards the main EU goals was enabled, promoting joint action through spreading best practice and setting guidelines and timetables for policy implementation (Ertl 2006, Longworth 2003). Even though, it is clearly stated that the Community "fully respects the responsibility of the Member States for the content of teaching and the organization of education systems", a new era in community collaboration in educational matters has been initiated, leading to a "European area of education" (Hingel 2001) and practically overriding the principle of "subsidiarity" as stated in the Treaty of Maastricht (1992).

\section{Aim of the study}

The present study seeks to provide a policy impact analysis through thorough review of Greek education and training policies undertaken to respond to the European challenges. In the light of the evolving Lisbon agenda, it takes account of the legal context and underlying principles of Greek educational policy with respect to LL, to draw upon the impact of an EU convergence policy activating educational initiatives and objectives to attain sustainable growth development.

In detail, the current analysis sets out to trace causality among various evidence in order to conceptualize and interpret phenomena of rising interest, as well as implementation of bodies and institutions in the field of LL in Greece. To this end, a thorough study of EU legal documents and legal context in Greece was conducted, seeking to identify interrelations between EU objectives and benchmarks, in the context of a common policy scheme to reach the Lisbon goals, and action undertaken by the Greek government to meet EU mandates. Finally, an assessment of strengths and weaknesses of initiatives launched by the Greek state in the field of LL, was attempted, so as to enable suggestion formation.

\section{The "Lisbon Impact" upon Greek Educational Policy}

The objectives set by the Lisbon Agenda focus on two closely interrelated parameters to meet the demands of overall development and economic growth: a) restoring full employment and b) enhancing social cohesion. Nevertheless both of them are strongly conditioned by a third variable, accessibility to knowledge throughout lifespan and openness of educational systems prioritising thus, adult education.

On the grounds of the Lisbon Council Conclusions, the emphasis was placed on employment, setting the goals to raise employment rates, reduce the average level of unemployment and increase the number of women in employment by 2010 (European Council 2000). The Greek government responded by implementing "Regional Action Plans for Employment" (PSDA), (Law 2874/2000), according to which Regional Councils are enacted, responsible for drawing up the National Action Plan for Employment (ESDA) so as to attain alignment with specialized regional needs.

Following the mandate of the Lisbon Council to reflect on common objectives for educational systems in Europe, the Education Council drew a report in 2001, submitted to the European Council in Stockholm, which adopted the "Concrete Future Objectives of Education and Training Systems" (European Council 2001). The Council identified new areas for joint actions at European level, enacting the "open method of co-ordination" to be applied in the implementation process, planned to last throughout the period 2001-2010. The three main objectives decided on by the Council, comprising 13 sub-objectives, were:

- Increasing quality and effectiveness of education and training systems

- Facilitating access to all education and training systems

- Opening up Education and Training systems to the world

Legislative action in Greece to meet the afore mentioned objectives, was taken through Law 2909/2001 (art.3), which 
enacted the renaming of the "General Secretariat of People's Education" (GGLE) into "General Secretariat of Adult Education" (GGEE), a modification significant on both symbolic and practical levels, reflecting the endeavour of the Greek Ministry of Education to comply with EU priorities regarding adult participation in LL. The responsibilities of the updated Secretariat comprise the planning and coordination of all formal and non-formal adult education and training activities. GGEE supervises the operation of Second Chance Schools (SDE), Adult Education Centers (KEE), Parents' Schools and Regional Committees for People's Education (NELE). The same Law (2909/2001) redefined the role of the Institute for Continuing Education and Training (IDEKE), established by LAW2327/1995, prescribing as its prime aim the technical and scientific support of all GGEE programs. Within the next year, a Presidential Decree (PD.142/2002) was issued to further clarify the organization and operation of IDEKE. More specifically its aims were defined as: a) scientific and technical support of LL programs, b) spreading of ICTs in adult education, c) trainers' ICT training, d) development of Distance Education, e) operation of European LL programs and f) development of educational material.

In Barcelona, in March 2002 the European Council endorsed the Work Programme "Education and Training 2010", calling for European education and training to become a world quality reference by 2010 . Moreover, it called for further action to introduce instruments to ensure the transparency of diplomas and qualifications (European Council 2002). A year later, the Council adopted five Reference Levels for European Average Performance in Education and Training (Benchmarks). More specifically, by 2010: a) an EU average rate of no more than $10 \%$ early school leavers should be achieved, b) the total number of graduates in mathematics, science and technology should increase by at least $15 \%$ while at the same time the level of gender imbalance should decrease, c) at least $85 \%$ of 22 year olds should have completed upper secondary education, d) the percentage of low-achieving 15 years old in reading literacy should have decreased by at least $20 \%$ compared to the year 2000 and e) the EU level of participation in LL, should be at least $12 ; 5 \%$ of the adult working age population (25-64 age group) (European Council 2003).

Greek institutional framework was further reformed by enacting National Committees for Employment and Social Protection, and initiating social dialogue, underlining the key-role of social partners in achieving wider acceptance of policies in order to raise employment rates and fight unemployment, both prerequisites for social cohesion enhancement (Law 3144/2003). Moreover, "Centres for the Promotion of Employment" were established, operating under the authority of OAED (Manpower Employment Organisation).

However, the first important legislative action to align with the "Lisbon agenda" was the implementation of an integrated legislative framework falling under the human resources development strategy. The establishment of the National System for Linking Vocational Education and Training with Employment (ESSEEKA) was enacted under Law $3191 / 2003$, in the light of an integrated approach of education and training of manpower and its channeling to the labor market. ESSEEKA provides the framework for effective coordination of the systems of Initial and Continuing Vocational Training, the recording of needs of the labor market, performed by the Employment Observatory (PAEP), and the formation of vocational frameworks, which lead to the development of reliable initial and continuing training curricula.

Even though there had been important improvements in the field of LL, participation percentage of adult population was far below European rates $(1 ; 1 \%$ in 2002), making the benchmark of $12 ; 5 \%$ by 2010 , appear unattainable. Thus, immediate action in order to optimize participation in LL, was taken through the implementation of Adult Education Centers (KEE) in 2003. Totally, 58 KEEs had been founded by 2007, operating in all regions of the country and making possible for adult education to extend its action to any citizen, in every part of the country in need for educational services, thus providing adult population with equal chances to integrate or reintegrate in working and social life and cope with constant social and vocational changes (Panitsidou 2007).

In the light of the follow-up on the effective implementation of the detailed work programme 2010, a Joint Interim Report was endorsed in 2004. The Report called for enhanced collaboration among member states and coherent national LL strategies to develop flexible and effective education and training systems, pointing out the existence of deficits in some areas which have to be addressed if the common objectives are to be attained. Therefore, it urged for higher and more efficient investment in human resources, development of more effective partnerships between key actors, validation of prior learning and creation of learning environments that are open, attractive and accessible to everyone, 
especially to disadvantaged groups (European Council 2004).

Identifying serious shortcomings and obvious delays in the progress made by member states towards the Lisbon goals, in March 2005 the European Council relaunched the Lisbon Strategy, refocusing on growth and employment and calling for urgent action on the basis competitiveness, productivity and social cohesion, placing the main emphasis on knowledge, innovation and optimization of human capital, "Europe's most important asset” (European Council 2005).

The Greek Government contributed to the revised Lisbon Strategy by submitting to the Committee a "National Reform Program for the period 2005-2008". The objectives of the Greek National Program comprised employment reinforcement, rise of public expenses for education to 5\% of the GDP by 2008 (a goal failed though, to be attained by the Greek Government), as well as undertaking of initiatives to improve flexibility, quality and effectiveness of the educational system (Greek Ministry of Economy, 2005). Nevertheless, it had not been but until 2005 that the Greek Ministry of Education implemented an integrated lifelong learning strategy in alignment with the Lisbon goals. Law 3369/2005 intended to establish an integrated legal framework for more efficient co-ordination and systemization of the Lifelong Education and Training actions and bodies. The reformed institutional framework attempts to cover all levels of lifelong education and training of the Public Sector, while it provides social partners with the potential to create LL bodies, targeting to increase active participation and strengthen social effectiveness. Furthermore, it makes provision for:

- distinction between Lifelong Education and Lifelong Training

- issues of providers of Lifelong Education and Training

- enacting of a collective body, named "National Committee for Lifelong Training", to improve coordination of lifelong education and training services and interconnect them to ESSEEKA bodies.

- formation of professional frameworks

- certification of qualifications and vocational skills

- funding and evaluation issues

In 2006 the European Parliament and Council jointly decided on the establishment of a programme for Community action in the field of lifelong learning, referred to as "the Lifelong Learning Programme", aiming to foster interchange, cooperation and mobility between education and training systems within the Community so that they become a world quality reference (Official Journal of the European Union 2006: art. 5). To meet the mandates arising for the establishment of "the Lifelong Learning Programme", the Greek parliament voted on the implementation of a National Coordination Body, under the name "Solon", to provide for effective administration of all EU programmes on LL (Law 3577/2007: art.2).

Since 2006, Communications from the European Commission have taken special interest in "promoting efficiency" and "ensuring the quality of adult learning", through "fostering a culture of quality of provision" (Commission of the European Communities 2006, 2007a, 2007b). To this end, "the quality of the staff involved in delivery", is set out as a key factor. As outlined, "so far in many Member States little attention has been paid to the training (initial and continuing), the status and the payment of adult learning staff", even though "the quality of staff is crucial in motivating adult learners to participate" (Commission of the European Communities 2007b: 9). To comply with these requirements, Greek Ministry of Education catered for the establishment of an Adult Educators' Inventory (Law 3687/2008 art.10), judging this initiative important to facilitate provision assurance of overall quality in the delivery of adult education programs.

\section{Conclusions}

Looking into the data accounted above, there is apparent evidence of influence of EU guidelines on policy implementation, in Greek educational policy for LL. Rising interest followed by legislative action for the establishment of novel bodies and institutions in the field of LL, derived in alignment with EU convergence educational policy to meet objectives and benchmarks in adult education as prescribed by the Lisbon agenda.

However, the whole effort entails two contradictory outcomes. The positive aspect is that, during the period 2000-2008, Greece emphasised on LL and investment in human and social capitals in order to raise productivity and accelerate 
development, as well as strengthen social cohesion. Thus, important legislative action was taken, concerning the update, development and quality improvement of the adult education system and its linking to employment. Moreover, social inclusion, accessibility to education, ICT skills improvement, as well as quality provision and assessment, became priorities for Greek educational policy in order to align with the Lisbon agenda mandates and promote adult education along with the establishment of a culture of LL.

Nevertheless, a qualitative study launched in 2007 in Adult Education Centers (KEE) (Panitsidou 2007), pointed to various controversies and lack of grounded planning in the policies endorsed by the Greek state. Moreover, extremely low percentage of participation of adult population in LL, far below EU levels (only 2;1\% in 2007), denotes serious shortcomings and deficiencies in measures taken. This can be attributed to three core parameters. Firstly, absence of research in Greece, leads to undisputed adoption of EU policies and practices, prohibiting alignment with particular needs of the local market and society.

Secondly, the bureaucratic structure of the public sector restrains flexibility and inhibits development of quality services. An example of such an inflexible and of questionable value for quality provision, practice, is the implementation of a centrally controlled Adult Educators' Inventory (Law 3687/2008), based on qualifications and competences doubtful to ensure quality, while limiting the potential of the bodies and institutions to employ competent educators unless the are registered in the Inventory.

Finally, what appears to be the most important handicap for all initiatives taking place in Greek LL area, is financing. Most programs and bodies operate under mainly EU funds, a parameter that inhibits flexibility in operation and full alignment with local needs. Thus, there is an urgent need for rise in National funds invested in adult education (barely $4 \%$ of the GDP is spent on all levels of education), to increase quality in LL programs delivery and moreover, ensure continuance of their operation when European funding ceases.

Concluding, we deem important that further action and more effective measures are required in order to provide the entire population in Greece, with the chance to acquire or update knowledge and skills and raise participation percentage in LL to levels comparable with those of other member states. To make this possible, we suggest: a) rational allocation of EU funds, b) substantial evaluation of LL programs, c) research programs launched in the field of LL, d) flexibility of the institutional framework to adapt to the "knowledge-led society" mandates, e) partnerships promotion between businesses, social partners and education institutions at all levels, to promote alignment with specific needs, $\mathrm{f}$ ) LL not limited to vocational training and education, as well as, g) rise in National funds invested in LL programs. It is high time the Greek authorities realized that investment in education is a crucial parameter to ensure sustainable development and social effectiveness, making available to all citizens a multitude of quality LL alternatives adapted to individual needs.

\section{References}

Commission of the European Communities. (2006). Communication from the Commission, Adult learning: It is never too late to learn. Anline] Available: http://eur-lex.europa.eu/LexUriServ/LexUriServ.do?uri=COM:2006:0614:FIN:EN:PDF (January 8, 2009)

Commission of the European Communities. (2007a). Communication from the Commission, A coherent framework of indicators and benchmarks for monitoring progress towards the Lisbon objectives in education and training. [Online] Available: http://eur-lex.europa.eu/LexUriServ/LexUriServ.do?uri=COM:2007:0061:FIN:EN:PDF (January 15, 2009)

Commission of the European Communities. (2007b). Communication from the Commission to the Council, the European Parliament, the European Economic and Social Committee and the Committee of the Regions, Action plan on adult learning: It is always a good time to learn. [Online] Available: http://eur-lex.europa.eu/LexUriServ/LexUriServ.do?uri=COM:2007:0558:FIN:EN:PDF (January 8, 2009)

De la Fuente, A., \& Ciccone, A. (2002). Human capital in a global and knowledge-based economy, Final Report. Brussels: European Commission

Ertl, H. (2006). European Union policies in education and training: the Lisbon agenda as a turning point? Comparative Education, 42, 1: 5-27

European Council. (2000). The Lisbon European Council: Presidency conclusions. [Online] Available: 
http://www.europarl.europa.eu/summits/lis1_en.htm (February 23, 2009)

European Council. (2001). Report from the Education Council to the European Council, The concrete future objectives of education and training [Online] Available: http://ec.europa.eu/education/policies/2010/doc/rep_fut_obj_en.pdf (February 23, 2009)

European Council. (2002). Presidency Conclusions, Barcelona. [Online] Available: http://ue.eu.int/ueDocs/cms_Data/docs/pressData/en/ec/71025.pdf (January 8, 2009)

European Council. (2003). Council conclusions on reference levels of European average performance in Education and Training (Benchmarks). [Online] Available: http://ec.europa.eu/education/policies/2010/doc/after-council-meeting_en.pdf (March 9, 2009)

European Council. (2004). Education and Training 2010: The success of the Lisbon Strategy hinges on urgent reforms. [Online] Available: http://ec.europa.eu/education/policies/2010/doc/jir_council_final.pdf (January 8, 2009)

European Council. (2005). Presidency Conclusions Relaunching the Lisbon Strategy, A partnership for growth and employment. [Online] Available: http://ue.eu.int/ueDocs/cms_Data/docs/pressdata/en/ec/84335.pdf (January 16, 2009)

Feinstein, L., \& Sabates, R. (2008). Adult learning: skills and social productivity. Ad-Lib, 35: 17-21

Giddens, A. (1990). The Consequences of Modernity. Cambridge: Polity Press

Greek Ministry of Economy. (2005). National Reform Programme for the period 2005-2008. Greece: Ministry of Economy (in Greek)

Greek Official Governmental Gazette. Law 2874 A’ 286/29.12.2000 (in Greek)

Greek Official Governmental Gazette. Law 2909 A' 90/02.05.2001 (in Greek)

Greek Official Governmental Gazette. Law 3144 A' 111/08.05.2003 (in Greek)

Greek Official Governmental Gazette. Law 3191 A' 258/07.11.2003 (in Greek)

Greek Official Governmental Gazette. Law 3369/2005 A' 171/06.07.2005 (in Greek)

Greek Official Governmental Gazette. Law 3577/2007 A' 130/8.6.2007 (in Greek)

Greek Official Governmental Gazette. Law 3687/2008 A' 159/1-8-2008 (in Greek)

Greek Official Governmental Gazette. P.D.142 A' 118/31.05.2002 (in Greek)

Hingel, A. (2001). Education policies and European governance. Brussels: European Commission

Kumar, K. (2005). From post-industrial to post-modern society: new theories of the contemporary world. Oxford: Blackwell Publishers

Longworth, N. (2003). Lifelong learning in action: transforming education for the $21^{\text {st }}$ century. London: Kogan Page.

Longworth, N. (2006). Learning cities, learning regions, learning communities: lifelong learning and local government. London: Routledge

Murphy, M. (2003). Covert action? Education, social policy and law in the European Union. Journal of Educational Policy, 18, 5: 551-562

Official Journal of the European Communities (1992). Treaty on European Union. [Online] Available http://eur-lex.europa.eu/en/treaties/dat/11992M/htm/11992M.html\#0001000001 (January 23, 2009)

Official Journal of the European Union (2006). Decision of the European Parliament and of the Council of 15 November 2006, establishing an action programme in the field of lifelong learning. [Online] Available: http://eur-lex.europa.eu/LexUriServ/site/en/oj/2006/1_327/1_32720061124en00450068.pdf (March 6, 2009)

Organization for Economic Cooperation and Development (OECD) (2003). Education at a glance: OECD Indicators. Paris: OECD Publishing

Panitsidou, E. (2007). Adult Education Centres (KEE) as an Institution of Continuing Education and Training: Evolution and perspective. Thesis, Thessaloniki: University of Macedonia (in Greek) 
Pearce, I. (2000). Education and social cohesion: An employers perspective. In Education and social cohesion: Education strategies for social cohesion and democratic security. Strasbourg: Council of Europe

Psacharopoulos, G.., \& Patrinos, C. (2002). Returns to investment in education: a further update. Washington, DC: World Bank

UNESCO (1976). Recommendation on the development of adult education. Paris: UNESCO

Vandamme, F. (2000). Education and social cohesion: the Council of Europe. In Education and social cohesion: Education strategies for social cohesion and democratic security. Strasbourg: Council of Europe 


\title{
The Impacts of British Policies and the IRA's Ideology on the 1981 Irish Hunger Strike
}

\author{
Lu Yan \\ The International Relations Institute of Nanjing University \\ Nanjing 210093, China \\ E-mail: yanluphyllis@hotmail.com
}

\begin{abstract}
The Northern Ireland question is the key question all over the world. The question is not only close related to the Britain and the Republic of Ireland, but also influences on Europe political and economic situation. Besides it, it is more important for the stability of West Europe. This essay is to list the conflicts between the British government and the Irish Republican Army in 1970s, to analyze the British government policies made to the IRA, to elaborate the IRA's own ideology, with the view to state their influences on the 1981 Irish hunger strike, and on the develop of the Northern Ireland question.
\end{abstract}

Keywords: British government policies, Irish Republican Army, Ideology, Special political status

The question of Northern Ireland has been one of the thorniest problems which British Government had to deal with. Not only has there been a profound and lasting historic background, but also interweaved complex contradictions of both race and religion. The Northern Ireland Question refers to a series of conflicts concerning the constitution, social economics, cultural identity, and religious difference. When it comes to 1968, Northern Ireland problem were getting thornier and thornier. The Irish Republican Army in Northern Ireland took a series of violence which seriously had an impact on the local social, economic development and people's livelihood stability. Entering into the 1970s, British policies, in this period were made in the purpose of suppression the IRA. Additionally, removal of Special Category Status also aimed at controlling the IRA's violence. The IRA, meanwhile, insisted to struggle for the union and freedom of Ireland, to put England out of Ireland and to set up 32-county Republic of Ireland, and to regain Special Political Status. The IRA finally launched the hunger strikes, involving the death of ten men in 1980-1981 that can be seen as the most tragedy event in Irish history. The hunger strike, which becomes a turning point in Northern Ireland problem, leads the IRA's violence to the peace process. This essay analyzes the British government policies made to the IRA, to elaborates the IRA's own ideology, with the view to state their influences on the 1981 Irish hunger strike, and on the develop of the Northern Ireland question.

\section{Britain's Policies towards the IRA from 1971 to 1979}

The years between the late 1960s and 1998 when the Belfast Agreement was signed, are often referred to as 'The Troubles'. This was a period of consistent conflicts and confrontations involving republicans and loyalist paramilitary organizations, the RUC, the British Army and other parties. From the 'Battle of the Bogside', from 12 August to 14 August in 1969, the situation in Northern Ireland can be described as a descent into violence. It had a strong and unprecedented impact on Northern Ireland. Derry and Belfast, where had stronger segregation, were involved in national antagonism, religious clash, military struggles. Facing with the confrontation between IRA and British army, and following the RUC, British government feared that it would threaten its rule. Therefore, policies, in different period 
were made in the purpose of suppression the IRA. After internment without trial, no-jury charge, disastrous ceasefire, criminalization, IRA being convicted as 'detainees', 'terrorist', and 'criminals' respectively, they finally launched the hunger strikes to struggle for their political status. To IRA, they are paramilitaries, fighting for Irish liberty and freedom.

In the early 1971, the first soldier and first IRA member was shot by the IRA and army respectively. Internment was demanded. Brain Faulkner produced a policy with a radical security initiative in the form of internment without trial, and he saw it as 'a panacea' (McKittrick, D. and McVea, D., 2000, PP. 67) both in halting violence and in improving the political atmosphere. A large-scale arrest, on 23 July 1971, codenamed 'Operation Demetrius' ( Holland, J., 1999, PP. 66) started with thousands of troops and police rounding up the IRA in Belfast and Derry with a copy of 452 listed names. Internment was provided under Section 12 of the Special Powers Act, which allowed suspects to be held without charge. Internment being in effect during the following four years, not a single Protestant was detained. Faulkner announced that 'the main target of the present operations is the Irish Republican Army.' (Adams, G., 1996, PP. 153) More IRA suspects were given special experimental interrogation treatment. The European Court of Human Rights characterized internment as 'inhuman and degrading' treatment. (McKittrick, D. and McVea, D., 2000, PP.68)

Merlyn Rees, turned towards the republicans and PIRA after Whitelaw's failure. Whitelaw once made attempted to talk with the IRA and sought for the possibility of the ceasefire in 1972. In autumn 1974, the PIRA maintained a concerted campaign both in Northern Ireland and England with numbers of bombs. (McKittrick, D. and McVea, D., 2000, PP. 69) Rees's strategy was 'to create the conditions in which the PIRA's military organization might be weakened. The longer the ceasefire lasted, the more difficult ... to start a campaign again ... this period of peace...political action would be given a chance.' (Rees, M., 1985, PP. 224) The talks between them lead to IRA ceasefires in 1974-75, although no evidence showed British withdrawal was possibility. During the ceasefire, Catholics and Protestants continued to be killed, which proved the ceasefire not much effectiveness. After the last internees being released by Rees, the IRA gradually returned to the offensive. (Bishop, P. and Mallie, E., 1987, PP. 224) In republicans' eyes, the ceasefire was a 'disaster'. (Bishop, P. and Mallie, E., 1987, PP. 217) From then on, the PIRA entered into the phrase of more offensive sectarian killing.

The British Labour government under Roy Mason considered Northern Ireland with security policy, instead of political policy that was proven as having no effectiveness. Rees' administration was eager to form security policy on the basis of more logical and effective approach. Mason and Kenneth Newman, the new Chief Constable of the RUC, seeking 'to undermine the whole political ethos of the struggle' produced the policy of 'Ulsterization, criminalization and normalization. (English, R., 2003, PP. 187-188) Among this coherent strategy, the concepts of 'Ulsterization' and 'criminalization' were important and controversial. Both of them, especially the more aggressive 'criminalization', paved a disaster road for PIRA, and directly resulted in PIRA hunger strikes in 1980-1981.

Ulsterization was a strategy similar to 'Vietnamization', with the purpose of improving the security system in Ulster. In practice, it ensured that the RUC and UDR would be reorganized and expanded, while British regular troops were meanwhile decreased in numbers gradually. Regular troops would eventually be replaced by the RUC and UDR, (McKittrick, D. and McVea, D., 2000, PP.123) both to confront IRA and loyalists paramilitary groups and to take charge of security in Northern Ireland. Criminalization, which only focused on the IRA and other paramilitary groups, meant criminalizing the IRA. They were to be deprived of any political status even once acknowledged and denied any political motivation, and were to be treated as 'ordinary decent criminals'. (McKittrick, D. and McVea, D., 2000, PP. 123)

Internment had been abolished at the end of 1975, when Rees released the last internees. With the police returned to front line fighting against the IRA, the Northern Ireland question was redefined as a law and order question instead of a political one. The relevant approach, therefore, produced to push the paramilitaries, especially the IRA behind bars again, using criminal courts. (McKittrick, D. and McVea, D., 2000, PP. 123) It meant that IRA members would be subjected to long-time, intensive and frequent interrogation without jury. And all that they did were viewed as ordinary crime without any political motivation. It would realize so-called Normalization and criminalization. This kind of approach confessions extracted from terrorist suspects, gradually developed and produced immediately disastrous results for the PIRA.

In practice, the British Government used criminal courts and interrogation. Two laws, the Emergency Provisions Act 
(EPA) and the Prevention of Terrorism Act (PTA) were passed to heavily support and improve its security policy. The EPA 1973, established the special 'no-jury Diplock Courts' (James, L., 1998, PP. 80) to deal solely with terrorist offenses. The no-jury courts were on the basis of the Lord Diplock report in 1972 which 'highlighted the fear of paramilitary intimidation of jurors', (McKittrick, D. and McVea, D., 2000, PP. 123) linking with abolishment of juries. Additionally, the EPA also involved the phasing out of internment without trial, although 'suspects could be held for seven days without being charged.' (Bishop, P. and Mallie, E., 1987, PP. 255) The PTA was enacted 1974, as a strong response towards the extension of PIRA bombs in Birmingham against the acceptability of the EPA. The PTA conceived of a special device called an exclusion order, which shows that any Northern Ireland citizens who were suspected of terrorist activities would not be allowed to enter into England, Scotland or Wales, and must be deported back to his province with no right to appeal. (Rees, M. 1985) The two laws were somehow 'draconian'. Home Secretary Roy Jenkins said that 'In combination they are unprecedented in peacetime. I believe they are fully justified to meet the clear and present danger.' (Conroy, J., 1988, PP. 92)

The combination of the two laws and Normalization policy had both immediate and potential impact on the PIRA. The new interrogation team consisted of re-organized detectives, new appointed specialist collators who took charge of gathering and analyzing evidence, and trained teams of interrogators. Castlereagh, in east Belfast, was referred to the interrogation centers. Paramilitary members, especially the PIRA were arrested and then received an intense interrogation, some of them were finally charged as serious offences. However, most confessions were extracted through either physical or psychological ill-treatment during interrogation. A PIRA 'Staff Report' blamed the IRA itself for 'not indoctrinating members with the psychological strength to resist interrogation.' (Hennessey, T., 1998) It is estimated that, between 1976 and 1979, about three thousand suspects were charged with terrorist offences, most of them based on confessions extracted from interrogation. (Bishop, P. and Mallie, E., 1987, PP. 255) Facing such interrogations, more and more doubts and challenges were made to its legality and impartiality.

Firstly, the challenge turned to the police, RUC, accused of abusing the power of extracting confessions. It is said that over 2800 people were arrested in 1977-78, however, only 35 percent were charged with any offence. (James, L., 1998, PP. 81) Secondly, more controversies focused on the impartiality of getting confession: whether the RUC forced the IRA to confess by any beatings and ill-treatments. Subsequently, Amnesty International made an official inquiry about ill-treatment, headed by Harry Bennett, an English Crown Court Judge. However, the outcome of the inquiry disappointed. Its report said that 'at least some of those injured while in police custody had not inflicted their wounds themselves.' (Bishop, P. and Mallie, E., 1987, PP. 255) It seemed to support such a charge. Thirdly, some paid attention to British 'draconian' legislation. More debates on the EPA and PTA led to a doubt on monitoring of the effect of the legislation. The London-based National Council for Civil Liberties argued that 'the laws violate international standards on human rights.' (Conroy, J., 1988, PP. 93)It was argued that no evidence showed any decrease in IRA terrorist activities. In reverse, it seemed to justify violence and increase terrorism in Northern Ireland.

\section{The Ideology of the IRA}

The hunger strikes in 1980-81 were guided by its shared political ideology, and motivated by the common interests and values, which showed its spontaneity and strong sense of comradeship. The IRA's activities were shaped by its republican doctrine which was 'essentially an expression of political and cultural nationalism' (Cronin, S., 1981, PP. 336) Furthermore, the IRA always belonging to Catholic community had been suppressed and segregated. In its eyes, continuing violence was the only effective force to struggle. Although they would be imprisoned, they would still take pride in imprisonment rather than take a shame. The IRA's extension of violence and resistance to removal of Special Political Status, were both the reflection of its loyalty to a traditional nationalism. Its view of Northern Ireland is summarized by two phrases: 'the people of Ireland form one nation'; and 'the fault for keeping Ireland divided lies with Britain.' (Whyte, J.H., 1990, PP. 118) Irish nationalism refers to political and sociological movements and sentiment that contains a love for Irish culture, language and a sense of pride in the island of Ireland. The wish of all people in island of Ireland to form one nation can be dated from the Act of Union of 1800 which declared the creation of the United Kingdom of Great Britain and Ireland. From then on, nationalism referred to a desire for greater autonomy or independence of Britain.

Almost all traditional nationalists attributed Unionist opposition to Irish unity to Britain's presence, and argued that 
Britain was eager to maintain its doctrine of 'Divide and Rule', (Gwynn, D., 1950, PP. 23) further control Northern Ireland to be its neo-colony. Gerry Adams, the President of Sinn Fein, holds a strong view that the root of Ireland's problem is the British presence. For him, the British presence deprived the Irish people of self-determination. (Adams, G., 1988, PP. 26) However, in his eyes, Unionists had the right to self-determination which was 'in direct contravention of the principle of self-determination.' (Adams, G., 1988, PP. 41) He also argued that Britain's control was not only over Northern Ireland, but a neo-colonial over the Republic. (Adams, G., 1988, PP. 32) P. S. O'Hegarty argued the view 'partition was primarily an English Conservative Policy, designed as propaganda to dish the Liberals.' (O' Hegarty, P. S., 1952, PP. 2-3) Frank Gallagher suggested 'Britain based her partition policy on divergences she herself created and fostered among the Irish people.' (Gallagher, F., 1957, PP. 88) And Denis Gwynn concluded that 'most people in Ireland take it for granted that Partition was deliberately devised by English politicians as a means of retaining a grip on Irish territory which could at any time be expanded.' (Gwynn, D., 1950, PP. 23)The issue of British presence was the key issue which IRA's radical republicanism fought against.

What the IRA was strongly dedicated to was the very aim of Irish nationalism: the removal of the British presence from Ireland. In fact, such firm belief had its historic root when the IRA appeared, for the first time, with a green flag in 1866. Colonel John Roberts, at that moment, had declared 'the green flag will be flying independently to freedom's breeze and we will have a base of operations from which we can not only emancipate Ireland but annihilate England.' (Kee, R., 1979, PP. 31) The name Irish Republican Army was gradually 'used to unite the disparate groups that made up the rebel forces,' (Bishop, P. and Mallie, E., 1987, PP. 7) always associating with countering English or British rule in Ireland. The members of the IRA viewed themselves as the United Irishmen founded as a Liberal Political organization in the eighteenth Century. The American Revolution and French Revolution broke out in succession in the eighteenth Century, which deeply affected its ideology with the thoughts of liberalism and democracy. The emigration of late nineteenth Century enriched it with 'an English-speaking world dimension' (Hachey, T. E., and McCaffrey, L. J., 1989, PP. 9) that included American egalitarianism, deeper democratic and republican dimensions. The organization of the IRA gradually shaped and improved its belief that all of Ireland should be a single independent republic, both in political and cultural aspects, whether as a unitary state, a federal state or as a confederate arrangement.

The IRA was a working-class organization based in the poorer rural areas and ghetto areas in the cities, (Cronin, S., 1981, PP. 342) often seeing itself 'as an 'Army' and clinging to the remnants of what they believed to be a military code of ethics', (Cronin, S., 1981, PP. 347) linking itself with emancipating Catholics and justifying activities as 'the only response to the repression of the Catholic community in Northern Ireland.' (Cronin, S., 1981, PP. 348) Members of the IRA from working-class Catholic families could gain esteem entering into the organization that viewed itself as 'an elite and exclusive band'. (Cronin, S., 1981, PP. 4) The sentiment of the emancipation of Catholics is traced from the late eighteenth century. Being a British colony, Ireland had been ruled by a Protestant minority. Since the Penal Laws' effectiveness, Protestant exclusivity was highlighted with the parliament perpetuating 'the religious, social, economic, and political disabilities'. (Hachey, T. E., and McCaffrey, L. J., 1989, PP. 2) After the partition of Ireland, Unionists, standing for the Protestants, had a majority at Stormont, declared to establish 'a Protestant parliament and a Protestant state' (Kelley, K., 1984, PP. 64) in the Six Counties. During the fifty years of Unionist rule at Stormont, from 1921 to 1972, the policy rejected the entire Catholic community being in power. Besides political power, Catholics were discriminated against in employment, housing, education, and social life, and were even excluded from recruiting the B Specials. (Belfast: H.M.S.O., 1972, PP. 92) From the emancipation of Catholics to Home Rule, from the Irish Free State to the Troubles, nationalists with Catholicism, especially republicanism, were struggling for a Catholic nation. This kind of combination of religion and nationality is the main characteristic of Irish nationalism.

When the struggles entered into the stage of birth of Northern Ireland, the communal violence escalated. It is estimated that 303 Catholics, 172 Protestants and 82 British soldiers (Bardon, J., A, 1992, PP. 494) were killed only July 1920 and July 1922, without the deaths during the Troubles. Facing such historic and continuing anti-Catholic prejudice, the IRA, particularly the PIRA, saw themselves as 'Catholic Defenders' (Cronin, S., 1981, PP. 195) in the North, and should have guns to defend themselves.

Physical force republicanism, following the violent tradition of the United Irishmen, had persisted until the late 1970s. After the late 1970s, Sinn Fein was dedicated to taking a strategy of using both armed struggle and electoral contests. The ideology of the IRA was violent, concerning two aspects: 'England's presence leads to violence' on the one hand, 
'England will not yield to any argument but force' (Cronin, S., 1981, PP. 207) on the other. In fact, the IRA was initially told, as soon as they recruited, that the involvement in republican movement would possibly lead them to Milltown or to Long Kesh, well known as Maze. (Bishop, P. and Mallie, E., 1987, PP. 1 ) Long Kesh was regarded as a particular prison in the eyes of republicans, 'synonymous with internment without trial, the 'hooded men' the protests for political status, the hunger strikes, and the escapes.' McKeown, L., 2001, PP. XII) To the IRA, republican prisoners who were convicted of using physical force were the prisoners of war, which was of 'honour to be worn with dignity'. After the Extraordinary Army Convention in 1969, the PIRA leadership, complying with the spirit of the 1916 Easter Rising, insisted that only the violence can achieve British withdrawal from Northern Ireland. (Cronin, S., 1981, PP. 340) San MacStiofain, the founder of PIRA, clearly declared that refused to do with any organization on the basis of 'their opposition to armed struggle.'(MacStiofain, S., 1975, PP. 135) Leading by such the ideology, republican prisoners decided to launch hunger strikes to maintain its honor and dignity.

\section{Special Political Status}

In 1972, William Whitelaw, the Northern Ireland Secretary, granted the PIRA 'special category status' (the Special Political status in nationalist or republicans' eyes), partly because Whitelaw was improving his relations with nationalists and republicans to discuss with the representatives of the IRA the possibility of a truce, after Britain's direct rule, and partly because the British government wanted to find some political solutions to removing more violence from streets. (McKeown, L., 2001, PP. 29)The consequence of the special category status was long-term, and the removal of it in 1975, finally gave rise to, the republican tragedy, the IRA hunger strikes in the 1980-1981.

How to deal with Irish political prisoners has been a thorny issue for British governments for a long time. The precise policy has depended on the current circumstances. From the Easter Rising of 1916 when the IRA, led by Sinn Fein, officially declared to struggle for liberty and independence and against the British presence, the IRA viewed itself as a paramilitary group fighting for a united Ireland. Therefore, in the IRA's eyes, their activists in Northern Ireland expressed political motives. With the growing number of republicans being imprisoned, they always insisted that they were prisoners of war. However, the British government's attitude towards the 'prisoners of war' has been indecisive sometimes, and has from time to time granted and withdrawn political status. To the IRA, if the demands for political status could not be realized, they always chose the method of prison protests. Tomlinson writes that 'Protests became much more collective and intense after the turn of the century. With the more decisive rising of 1916, there was so much more at stake for political prisoners with the immediate prospect of liberating Ireland from British rule ... The form of protest, whether against imprisonment, internment or military detention, changed dramatically. ... The hunger strike became the dominant form of protest.' (Mike Tomlinson, 1995, PP. 245)

The Hunger Strike is widely used as a method of political protest in Northern Ireland. And this strong tradition can be seen as an integral part of Irish history. From the early twentieth century, many hunger strikes were involved in struggle against prison conditions and the treatment of prisoners. Others concerned demands for political status and perceived unjust imprisonment. (Sweeney, G., 1993, PP. 421-437) In republicans' opinion, the hunger strike, being a political protest, is a reflection of resistance to British oppression and pursuit of its own political belief. Additionally, it is always, in term of Catholic, a sort of martyrdom. The strikers are, therefore, regarded as Irish heroes. In 1917, eighty-four republican prisoners, leaded by Thomas Ashe, launched a hunger strike for political status, which was viewed as a turning point in gathering support for the demand for political status. Bobby Sands, starving himself to death in prison in 1981, is seen as a republican hero by the Irish, and obtained a great amount of people's sympathies. From Thomas Ashe to Bobby Sands, the hunger strike protest truly reflects the political nature of the IRA's struggle.

Among republican hunger strikes, on May 1972, there was a hunger strike launched by Bill McKee in Crumlin Road Prison to demand political status which was 'always done in the prisons all through the periods.' (McKeown, L., 2001, PP.28) After a prisoner being removed to the Boards, other prisoners launched the protest to ask for his return to the wing. When the prisoners were told that it was impossible to let the prisoner return, the prisoners demand for the political status took place, involving in five demands: (McKeown, L., 2001, PP.28) the right to not wear prison uniform, to be segregated from criminal prisoners, to be excluded from prison works, to receive letters and parcels, and to freely visit someone. The hunger strike did not last long and all demands were granted to IRA prisoners immediately, because of the improving relations between British government and republicans. However, it was called 'special category status', 
which was evident to avoid the term of 'political'. It can be seen that British government did not regard this special category status as a kind of political sense.

Whitelaw's special category status was a direct cause for hunger strikes in 1980-1981 on one hand. The success of the 1972 hunger strike, to some extent, convinced the IRA that the hunger strike was an effective protest, which contributed to the tragedy of 1981, on the other hand.

From the analysis above, the IRA can be described as a descent into the violence. It took more aggressive actions to struggle for the union of Ireland. In order to stabilize the political situation, safeguard national security, the British policies changed political policy to security policy. The British government not only regarded the IRA as terrorists, carried out internment without trial, and forced the IRA to sign the ceasefire agreement, but also adopted a policy of Ulsterisation referring the republican prisoners as common criminals rather than political prisoners. The British Government removed the Special Political Status and deprived the IRA of political motives so that the IRA's confrontational emotion peaked at the climax of history. A series of policies that Britain made focused on undermining the strength of the IRA, decreasing Britain's domestic violence. The IRA was a working-class organization based in the poorer rural areas and ghetto areas in the cities, usually seeing themselves as an 'Army', linking themselves with emancipating Catholics and justifying their violent activities as the response to repression of the Catholic community. (Cronin, S., 1981, PP. 347-348) In the IRA's eyes, their activists in Northern Ireland were power of political motives. With the growing number of republicans being imprisoned, they always insisted that they were prisoners of war. The tension between Britain and the IRA was deteriorating in 1970s. The confrontation between the Britain's policies and the IRA's ideology was in a cycle of repression and anti-repression, violence and counter-violence. This unstable relation paved a way for the IRA extreme protests, and ultimately launched the hunger strikes in 1980-1981.

\section{References}

Adams, G. (1988). A Pathway to Peace. Cork: Mercier.

Adams, G.. (1996). Before the Dawn: An Autobiography. London: Heinemann.

Bardon, J. ( 1992). A History of Ulster. Belfast: Blackstaff Press.

Bishop, P. and Mallie, E. (1987). The Provisional IRA. London.

Chairman: Lord Justice Scarman. (1972). Violence And Civil Disturbances in Northern Ireland in 1969: Report of Tribunal of Inquiry. Belfast: H.M.S.O.

Cronin, S. (1981). Irish Nationalism: A History of its Roots and Ideology. New York.

English, R. (2003). Armed Struggle: The History of the IRA. Oxford.

Gallagher, F. (1957). The Indivisible Island: The History of The Partition of Ireland. London.

Gwynn, D. (1950). The History of Partition (1912-1925). Dublin.

Hachey, T. E., and McCaffrey, L. J. (1989). Perspectives on Irish Nationalism. Lexington: University Press of Kentucky.

Hennessey, T. (1998). A History of Northern Ireland: 1920-1996. Basingstoke.

Holland, J. (1999). Hope against history: the course of conflict in Northern Ireland. Hodder\&Stoughton.

James, L. (1998). The Ulster Question since 1945. Basingstoke: Macmillan Press.

Kee, R. (1979). The Bold Fenian Men. London.

Kelley, K. (1984). The Longest War. London.

MacStiofain, S. (1975). Memoirs of a Revolutionary. Edinburgh.

McKeown, L. (2001). Out of Time: Irish Republican Prisoners Long Kesh 1972-2000. Belfast: Beyond the Pale.

McKittrick, D. and McVea, D. (2000). Making Sense of the Troubles. The Blackstaff Press.

Mike Tomlinson. (1995). Imprisoned Ireland in Vincenzo Ruggiero. In Mick Ryan and Joe Sim, (Eds.), European Prisons Systems: a critical perspective. London. PP. 245 
O’ Hegarty, P. S. (1952). A History of Ireland under the Union. Methuen.

Rees, M. (1985). Northern Ireland: A Personal Perspective. Methuen, London.

Sweeney, G. (Jul., 1993). Irish Hunger Strikes and the Cult of Self-Sacrifice. Journal of Contemporary History, Vol. 28, No. 3, 421-437; 424.

Whyte, J.H. (1990). Interpreting Northern Ireland. Oxford: Clarendon. 


\title{
Maintaining the Standard Ukrainian Language: A Challenge for Teachers in Australia
}

\author{
Halyna Koscharsky \\ Macquarie University \\ NSW 2109, Sydney, Australia \\ Tel: 437-143-576 E-mail: halyna.koscharsky@humn.mq.edu.au \\ Geoffrey Hull \\ University of Western Sydney \\ Locked bag 1797, Sth Penrith DC, NSW 1797, Sydney, Australia \\ Tel: 438-235-061_E-mail: auriga5@optusnet.com.au
}

The research for this paper was sponsored by the Ukrainian Studies Foundation in Australia.

\begin{abstract}
The paper deals with problems of preservation of the Ukrainian language in Australia, based on the 25-year experience of one of the authors, in teaching Ukrainian studies at Macquarie University in Sydney. Against a background of growing assimilation and the dying away of Multiculturalism as a government policy, the authors examine the structure and history of the Ukrainian community in order to explain the characteristics of dialect-influenced spoken Ukrainian, and set up categories for the other main phenomena of linguistic interference in the areas of phonology and morphosyntax.

As a parallel concern, they consider a problem with special relevance in the Ukrainian homeland today, at a time when the direction of language planning is an important issue: the gap between modern standard Ukrainian and the different varieties of Ukrainian found in the diaspora.
\end{abstract}

Keywords: Language preservation, Ukrainian in Australia, Linguistic interference, Dialectal Ukrainian

\section{External Factors}

\subsection{Ukrainian in Post-Multicultural Australia}

The preservation of the Ukrainian language in Australia and other countries of the diaspora is unfortunately a little-researched subject. In general, questions of linguistic ecology and multiculturalism, while of increasing concern to Australian scholars in the 1970s and 1980s, have ceased to be of great interest to them in this century because of a widespread feeling within the English-speaking population that certain ethnic groups who had recently settled in Australia had not fully accepted this country's values. These groups have been growing in numbers at a rapid pace, their cultures stand in sharp and conspicuous contrast to that of ordinary Australians, and they show little or no inclination to assimilate to the majority of the population. As a result the multicultural era can be considered to be over, and with it 
the preparedness of the government to support and finance strongly the means of preserving ethnic languages. Among the victims of this change in attitude have been ethnic schools, radio programs and even grants for research in this area.

Meanwhile assimilation has taken its toll on the 37,500-strong Ukrainian population of Australia. (Note 1) In community schools, secondary schools and institutes of higher learning the number of students who enroll in Ukrainian-specific subjects has significantly fallen in the past 15 years. At the same time the number of migrants from Ukraine has increased by seven and a half thousand. Of these, a small percentage has joined the local Ukrainian community. However, when these new arrivals encounter local Ukrainian youth at scout camps for young people organized by the Plast and SUM movements or at social functions or the Ukrainian Saturday schools, they notice differences in the way Ukrainian Australians speak the Ukrainian language, even to the extent that members of the two groups can have considerable difficulty understanding each other. Before we look at the kind of language used by Ukrainians in Australia, it will be useful to present a brief historical overview of Ukrainian settlement in this country, and especially the provenance of the people who arrived here in 1948 and 1949, because it was their varieties of Ukrainian that set the linguistic habits of the following generations.

\subsection{Origins of the Australian Ukrainian Community}

Professor Eugene Seneta, in the English-language paper "Ukrainians in the 1986 Census", which he delivered in Sydney in 1988 at the fourth conference on the History of Ukrainian Settlement in Australia, observed that "the proportion of Orthodox in the Catholic-Orthodox group is 40.5\%" (Seneta, 1988; 82). In that year, when Australia was celebrating its bicentenary, Professor Lubomyr Lawriwsky wrote the following about the Ukrainian community in his article for the monumental work The Australian People: "In contrast to the situation in Ukraine, about two-thirds of the Ukrainian migrants [to Australia] were Catholics. It had been easier for them to escape to the West because they were geographically closer in Western Ukraine, and it was harder to repatriate them forcibly after the war [to the expanded Soviet Ukraine] because they had been pre-war citizens of Poland" (Lawriwsky, 1988;826). The general figure for Australian residents of Ukrainian origin (i.e. from both pre-war Soviet Ukraine and pre-war Eastern Poland) was 32,000 according to Seneta's detailed calculations based on census responses.

By contrast, over the past 20 years when greater numbers of people from the Soviet Union migrated to Australia, the proportion of Orthodox has slowly increased. According to the 2006 census, about $45.5 \%$ per cent of that section of the Australian population who designated their religion as 'Ukrainian Christian' declared themselves Orthodox, and the remainder, predominantly from the single region of Galicia, identified themselves as Ukrainian Catholics. (Note 2) Given the important fact that migrants from formerly Polish Volhynia and Western Polissia are generally Orthodox, not Catholic, in faith, one can therefore conclude that the larger half of the Ukrainian population of Australia is solidly Western Ukrainian in origin. This is obviously mirrored in the speech habits of these people and their children.

\section{Ukrainian Abroad}

\subsection{The linguistic character of the Ukrainian Diaspora community}

We mention this proportion because the regional differences in the language of the young (and not so young) Australian Ukrainians who have enrolled in Ukrainian courses at Macquarie University over the past 25 years strongly reflected their parents' places of origin as well as their level of Ukrainian and their English education. It often happens that a highly educated person with a good profession comes from a family in which standard Ukrainian is not spoken, but rather a regional variety. It is easy to imagine the feelings of such individuals when they are called upon to express their thoughts at meetings of the Ukrainian community. Fear of appearing foolish increasingly inhibits their speaking of Ukrainian in public and drives them to express themselves in English instead.

From the sociolinguistic and cultural standpoints this inferiority complex on the part of dialect speakers is unfortunate, because all regional varieties of a language are valid and valuable systems of communication, and standard varieties are, after all, arbitrary conventions. In European countries like Germany and Italy there is a strong tradition of cherishing dialects, many which indeed have their own literatures, sometimes boasting distinguished poets and writers, and this is seen to enrich rather than detract from the national cultural heritage. Ukraine, by contrast, suffers from a degree of linguistic insecurity, given the great effort made to create a literary standard and to assert its right to exist. In such a situation dialects are easily undervalued and stigmatized, though one hopes that as standard Ukrainian gains greater 
stability, linguistic confidence of an inclusive kind will increase, and due respect for regional varieties of the language will be restored.

At the 1998 conference, Archpriest Ivan Szewciw remarked that the first Ukrainian settlers in Australia "were common people, formerly members of the peasantry and even then from the poorest socio-economic bracket, with a small percentage of members of the intelligentsia (that is, people with a university education: 1-2\%) or petit bourgeois, small business owners and traders from our villages and little towns who, during the war, had willingly or unwillingly found themselves in Germany for compulsory labour or who had fled before the Bolshevik advance after the retreat of the German army from Ukraine" (Szewciw, 1990;72). According to Fr Szewciw the membership of the Ukrainian Catholic Church in Australia in 1988 was estimated to be about 23,000. While this figure for Catholics is much higher than the one given in the 1986 census, it is based on the number of faithful registered in Ukrainian Catholic parishes in Australia. This extra data is worth taking into account in order to get a clearer view of the provenance and regional characteristics of the language spoken by the second and third generations.

\subsection{Teaching Ukrainian in the Diaspora}

In spite of the preponderance of people from Western Ukraine, Ukrainian schools and language publications in Australia have adhered to the standard literary language which had been brought from Europe and have avoided dialectal forms. Hence the challenge for teachers has always been not only to teach standard Ukrainian to the young but also to correct the regionalisms in the speech of those who have grown up hearing and using a regional variant. It suffices to read an English-language article by Dr Olga Dudinski, entitled "Ukrainian Schools in Victoria: Perspectives, Needs and Planning" to see that the struggle to preserve the hereditary language, in the face of the everyday and official pressures of English, is a longstanding phenomenon (Dudinski, 1988;24).

The Ukrainian school system was established in the 1950s, not long after the arrival in Australia of the most numerous wave of Ukrainian immigrants. However, she reports on a student survey conducted between 1987 and 1988, which revealed that although they viewed the maintenance of their identity as an important or very important task, the majority of young Ukrainian Australians were using English in their relations with their parents, siblings and Ukrainian friends. Only with their grandparents did they speak their hereditary language, of course for the reason that the older generation had a poor command of English. The situation has obviously worsened since these students have grown up and become parents themselves. An analogous situation exists in the other Ukrainian diasporas, although the number of migrants in Canada and the United States is evidently greater.

\section{Internal Variation}

\subsection{Dialect as a pedagogical challenge}

Scholars have for a long time been researching the regional differences within the Ukrainian language. One of the most significant products of this discipline is surely the three-volume Atlas of the Ukrainian Language edited by I. H. Matvijas (1984-1992). This work follows the generally-accepted division of Ukrainian into three principal groups of dialects: the northern, the south-eastern and the south-western, all subdivided further into numerous local subdialects. The group most relevant to our interest is the south-western, because a majority of Australian Ukrainians are from Galicia, Volhynia and Bukovina, and because the south-western dialects also happen to be those that diverge most from the standard language. The speech of immigrants from the eastern and northern regions is distinctive but, apart from Russian influence, typically diverges far less from Standard Ukrainian (based as this is on a south-eastern dialect) than do the dialects of the south-west, which were additionally influenced by Polish and (in Bukovina) by Romanian in the period when migration to Australia began.

It is worth mentioning that the questions and problems relating to the preservation of ethnic languages are now being analysed within the framework of a research project at the Language and Society Centre at Monash University. Researchers have been monitoring the loss of the family languages over three generations of the Italian migrant community in the locality of Myrtleford, in the Victorian High Country north-east of Melbourne. The aim of the researchers is to make a quantitative and qualitative comparison between the Italian community and other ethnic groups who live outside the big cities. For this project they will use data from the last census in order to draw a map illustrating the multilingualism that exists in the small towns of Victoria. (Note 3) 
As for Ukrainian, generally speaking two kinds of problem are encountered by teachers of the standard language in this country: the student's home dialect and pressures from English. As educators and researchers, we have attempted to identify those elements in the structure of standard Ukrainian which are most susceptible to these two erosive influences and to find the best way to remedy them. These are predominantly problems of pronunciation, vocabulary, grammar and syntax since we have found that Australian Ukrainian students almost without exception quickly learn to read and write the Cyrillic alphabet. In our previous research project (Hull \& Koscharsky, 2006) we concentrated on the lexical differences between eastern and western varieties of Ukrainian. In our current research we are endeavoring to set up categories for the other main phenomena of linguistic interference in the areas of phonology and morphosyntax.

\subsection{Characteristics of dialect-influenced spoken Ukrainian}

Some typical examples of the structural divergences from the standard include the following. These are taken from the Linguistic Atlas; one of our objectives is to assess the occurrence of the same or similar dialectalisms in the vernacular varieties of south-western Ukrainian used in Australia.

\subsubsection{Vocalism}

In the vowel system there is the tendency to substitute both tonic and atonic vowels:

вечери (standard вечори) 'evenings', воге́нь, оге́нь (вого́нь) 'fire’, богато леду (багато льоду) 'a lot of ice', зелізо (залізо) 'iron’, дрива́ (дрова) 'firewood', брива́ (брова́) 'eyebrow', слеза (сльоза) 'tear', пір'є (пір’я) 'feathers', зазуля (зозуля) 'cuckoo', видро (відро) 'bucket', цьвох, цьвих (цвях) 'nail’, життє́ (життя) 'life’, щесть, щість (щастя) 'happiness' or 'good luck', икономіка (економіка) 'еconomics', глібокий, глобокий (глибокий) 'deep', їде́н, єде́н (один) ‘оne’, дев'їть (дев’ять) 'nine', шестий (шостий) 'sixth', сперше (спершу) 'at first'.

\subsubsection{Consonantism}

Phonemic substitutions and additions also affect consonantism:

рімний (рівний) 'even, level', дамно (давно) 'long ago', мнясо (м'ясо) 'meat', памнять (пам'ять) 'mеmory', надгорода (нагорода) 'reward', тачалка (качалка) 'rolling pin', гойданка (гойдалка) 'swing', позівати (позіхати) 'to yawn'; кирниця (криниця) ‘well, spring' (here, a typical case of metathesis).

Apart from the above random examples, there are phonetic divergences from literary Ukrainian following a more regular pattern, such as

$\Phi$ - instead of кв, х(в)-, in imitation of Polish, a characteristic of uneducated speech:

фасоля (квасоля) ‘beans', фалити (хвалити) ‘to praise', футро (хутро) ‘fur', фіст (хвіст) 'tail', филя (хвиля) 'wave'.

Use of the sound/letter $r$, corresponding to Polish norms in words in which $\Gamma$ was substituted in Soviet Ukrainian; this feature tends still to be normal in the educated pronunciation of many diaspora Ukrainians, as a measure of overcompensation for its long absence in Ukraine :

газ (газ) 'gas’, гіпс (гіпс) 'plaster’, гвинт (гвинт) ‘screw', агент (агент) ‘agent', енергія (енергія) ‘energy', Бельгія (Бельгія) ‘Belgium’, Англія (Англія) ‘England’, англійський (англійський) ‘English'.

Alternations in sibilant and assibilant consonants often characterize Western Ukrainian, cf. цкло (шкло) 'glass', скіра, скора (шкіра, шкура) ‘skin' or 'hide’, кукуруза (кукурудза) 'таize’, дзелений (зелений) 'green', дзерно (зерно) 'grain'.

In the extreme western Galician dialects bordering on Polish one finds a spontaneous unvoicing of final voiced consonants, as in Polish (and also Russian): город 'garden' > горот, без 'without' > бес, муж 'male; husband' > муш, щоб 'sо that' > щоп.

Widespread in the western dialects is the addition of initial в- to words beginning in a back vowel, and conversely the opposite phenomenon, e.g. вогірок (огірок) 'cucumber', возеро (озеро) 'lake', вовес (овес) 'оаts', восінь (осінь) 'autumn'; узький (вузький) 'narrow'. A related phenomenon is the dropping, or replacement by в-, of words beginning in го-, е.g. оробець, воробець (горобець) 'sparrow'. 
Very typical of Galician pronunciation is advanced palatalization (again, often on the model of Polish phonology) not usual in standard Ukrainian, e.g. сь > ш: сьогодні > шогодні 'today', сім > шім 'seven'; свя > сьв: святий > сьватий 'holy'; в'я > вля: здоров'я > здоровля 'health'.

Conversely the absence of palatalization normal in standard Ukrainian can be a Galician feature, cf. хлопец (хлопець) 'boy', мелник (мельник) 'miller', пам'ят (пам'ять) 'memory'; ходит (ходить) 'he/she goes', будут (будуть) 'they will be'; сине (синє) 'blue', теперішне (теперішнє) 'present, current', господне (господнє) 'of the Lord'.

The cardinal numerals 11-19 have a range of phonetic variants in the Western dialects: одинасцять 'eleven', may be pronounced: одина́йцять, одина́дсіть, одина́дцеть, оr одина́нсіть. Standard двісті 'two hundred' often occurs as двіста.

\subsubsection{General Polish influences in word formation}

As examples of sporadic phonetic changes and phonemic substitutions caused by the Polish superstratum in this region one can cite:

злото = P. złoto (золото) 'gold', япко = jabko (яблуко) 'apple', бласк = blask (блиск) 'lightning', дюр(к)a = dziur(k)a (дір(к)a) 'hole', пчола́ = pszczoła (бджола) 'bee’, вуль = ul (вулик) 'beehive', цьотка = ciotka (тітка) 'aunt', тесля = cieśla (тесляр) 'carpenter', дентист(a) = dentysta (дантист) 'dentist', Андрей = Andrzej (Андрій) 'Andrew', Ева = Eva (Єва) 'Eve', лижка = tyżka (ложка) 'spoon', трумнна = trumna (труна) 'coffin', бубен = bęben (бубон) 'drum', пєц = piec (піч) 'oven', коперта = koperta (конверт) 'envelope', (i)гла́ = igla (голка) 'needle', шампон(ь) = szampon (шампунь) 'shampoo', почта = poczta (пошта) 'mail', богатий = bogaty (багатий) 'rich', хорий ' chory (хворий) 'sick', горячий = goracy (гарячий) 'hot'.

The placement of stress particularly distinguishes these dialects, and students whose parents come from Western Ukraine will regularly pronounce words which are oxytones or proparoxytones in the standard language as paroxytones, in the Polish manner: зокре́ма (зокрема́) 'specifically’, зо́ря (зоря́) 'star', бло́ха (блоха́) 'flea', пару́бок (па́рубок) ‘bachelor', доля́ри (до́ляри) ‘dollars'. Less commonly the opposite occurs, cf. ворота́ (воро́та) 'gate’.

This phenomenon is particularly noticeable in the first person singular of many verbs: я говорю' ‘I speak' > я говорю, я скажу́ 'I will say' > я ска́жу, я про́бую 'I try' > я пробу'ю, я люблю́ 'I love; I like' > я люблю. However, this Galician trait does not generally affect adjectives stressed on the last syllable like мали́й 'small', смачний 'tasty', страшний 'terrible'.

\subsubsection{Morphosyntactic features}

One grammatical difference between the Ukrainian of the diaspora and that of the home country is the distinctive genitive singular ending of feminine nouns ending in a consonant, that is, - и instead of $-\mathrm{i}$, e.g. радости = радості 'of јоу', соли = солі 'of salt', вогкости = вогкості 'of wetness'. In these cases the standard language accepts both variants, as do teachers of Ukrainian abroad.

By contrast, numerous other morphological variants typical of Western Ukrainian are not accepted in the standard, even in the polonized literary language of the diaspora. Such non-standard forms, which teachers need to correct, include:

мойо́го, твойо́г (мого, твого) 'of ту' 'of 'your', братови (братові) 'to the brother', дощом (дощем) 'by the rain', серцом (серцем) 'with the heart', соле́у (сіллю) 'with salt', неу (нею) 'with her', зі мноу (зо мною) 'with me', людий (людей) 'of people', гроший (грошей) 'of money', на коньох (на конях) 'on horses', у земли (у землі) 'in the earth'.

It is noteworthy that students whose parents come from Western Ukraine do not often use the vocative case (a feature also typical of colloquial Polish). The same students characteristically simplify the feminine singular locative ending iй to i, e.g. о перші (о першій) 'at one o'clock', о шості (о шостій) 'at six o'clock'. Related to this appears to be the substitution of the genitive form iii for the dative feminine form ій in the third person singular pronoun вона 'she'. Dialectal influence is also responsible for frequent errors in the pronunciation of unstressed vowels, e.g. в лікарну (в лікарню) 'to hospital', пречена (причина) 'cause', добри (добре) 'well' or 'good'.

Dialectal speech habits affect morphosyntactic sequences and idioms to the extent that students who already speak a variety of Ukrainian fluently have to be taught which are standard/literary and which are non-standard/colloquial. 
Typical examples are наші госці (наші гості) ‘our guests', дві руці (дві руки) 'two hands', дві жінці (дві жінки) 'two women', ся жінка (ця жінка) 'this woman', тамта жінка (та жінка) 'that woman', він ся/сі миє (він миється) 'he washes himself', вона сі бавить (собі бавиться) 'she amuses herself', ти дась, ти їсь (даси, їси) 'уou give; you eat' (sg.), ми ходи́лисмо (ми ходили) 'we went', ходьме (ходімо, ходім) 'let's go', буду брав (буду брати) 'I’ll be taking', я дав бим, ти даш бис(ь) (я дав би, ти дав би) 'I would give; you would give'; називаюся Іван (мене звуть/звати Іван) 'ту name is Ivan', and so forth.

\subsubsection{Impact of the English superstratum}

Naturally all Australian-born students of Ukrainian are constantly tempted to translate literally from English when they speak and write their ancestral language. Hence teachers have to contend with such expressions as зранку суботу (зранку в суботу) 'Saturday morning' and більшість австралійці (більшість австралійців) 'тоst Australians'. Many of these linguistic interferences occur in a regular fashion, for example the tendency to include incorrectly the preposition ' 3 ' in instrumental constructions such as Я пишу з олівцем 'I write with a pencil', Я їм з ложкою 'I eat with a spoon'; the periphrastic expression of the dative: мені > до мене 'to me', собі > до себе 'to уоu', своїй мамі > до своєї мами 'to his mother'; and the incorrect use of the accusative instead of the genitive case in negative sentences, e.g. Я не маю цибулю (цибулі), плащ (плаща), гроші (грошей) 'I don’t have an onion/a coat/money'.

\section{Conclusions}

Having highlighted some of the main obstacles to the teaching of standard Ukrainian in Australia, it seems appropriate to end this paper by considering a problem with special relevance in the Ukrainian homeland today, at a time when the direction of language planning is an important issue. The gap between modern standard Ukrainian and the different varieties of Ukrainian found in the diaspora is not simply a pedagogical question of dialect and/or anglicism versus 'correct' language.

The reality that most writers of Ukrainian abroad and overseas Ukrainian organizations have remained attached to the polonized variety of literary Ukrainian established in Galicia before 1944 means that the teachers of Ukrainian in the diaspora have to contend with two often conflicting models as they strive to teach a standard form of the language to speakers of dialectal and/or anglicized Ukrainian. In the meantime Literary Western Ukrainian has become largely obsolete in its home territories of Galicia and Volhynia, replaced by the standard variety from Kyiv after these regions were incorporated into Soviet Ukraine during the Second World War. Of this literary medium Jurko Proxas'ko (2008;22) recently wrote that "There is no longer a Galician Ukrainian language. [...] What is left of it? Several hundred words (it would appear, but perhaps I exaggerate), several dozen characteristic traces, a few aspects of syntax, and a few dozen other particulars apart from accent and intonation, features too obvious to mention."

This may be the perception in Ukraine today, but the reality abroad is that Western Literary Ukrainian remains as vital as ever. Indeed the longstanding preponderance of Western Ukrainians in the diaspora has created a situation in which, overseas at least, the old Galician standard cannot simply be dismissed as a minority or peripheral phenomenon or as an anachronism. On the contrary, after the former Polish Ukraine was annexed by the Soviets, the high profile of Western Literary Ukrainian in the disapora was strengthened by its close association with anti-Soviet and anti-Russian movements and its being the medium of a vibrant literature.

The independence of Ukraine has set in motion the process of dissolving this enforced division. Yet although the two standards have been coming together to some extent since 1991, both in Ukraine and abroad, the synthesis is still far from complete. If diaspora Ukrainians remain reluctant to be converted to what many of them dislike as 'russified Ukrainian', Ukrainians at home need to come to terms with the 'polonized' linguistic tradition of a diaspora which has made an important contribution to Ukrainian literature for over a century.

It is our view that this incomplete synthesis, far from being a weakness of Ukrainian today, rather offers a unique opportunity for its development in the post-Soviet era. Since it has been the historical fate of Ukraine to be wedged between two powerful neighbours, the Polish and Russian languages have inevitably played formative roles in the evolution of the Ukrainian language, and the proportions and depth of their respective influences is a question of the highest importance. 
It has long been the genius of Ukrainian to bow at times - even for long periods - to these influences without sacrificing the essence of its distinct identity. During the long period of Soviet domination of the country the pendulum swung in the direction of Russian. Perhaps in the interest of restoring what is in essence a delicate balance, the time has come for the pendulum to swing westwards again. If this were to happen in the context of a carefully planned strategy of language planners, the Galician literary language which still flourishes in the diaspora could provide domestic Ukrainian with a template of Western European and international vocabulary transmitted through Polish, as an antidote to the recent overdose of Russian influence. In this sense the contribution of diaspora Ukrainianists and writers can be useful, providing new perspectives and concrete models for a language justly determined to assert itself in a new climate of freedom.

\section{References}

Dudinski, O. et al. (1988). Ukrainian schooling in Victoria: Perspectives, needs and Planning. In Gordijew, I. and Koscharsky, H. (eds.). Ukrainian settlement in Australia (Fourth conference). Sydney: School of Modern Languages, Macquarie University, 24.

Hull, G. and Koscharsky, H. (2006). Contours and consequences of the lexical divide in Ukrainian. Australian Slavonic and East European Studies, Vol 20, Nos 1-2, 139-172.

Lawriwsky, M. (1988). Ukrainians. In Jupp, J. (ed.). The Australian people: An encyclopedia of the nation, its people and their origins. Sydney: Angus \& Robertson, 825-828.

Matvijas, I. H. (ed.) (1984, 1988, 1992). Atlas ukrajins'koji movy (AUM). 3 vols. Kyiv: Naukova dumka, Akademija nauk ukrajins'koji RSR, Instytut movoznavstva im. O.O. Potebni, Instytut suspil'nyx nauk.

Proxas'ko, J. (2008). Krytyka movy. Krytyka, 12, 22.

Seneta, E. (1988). Ukrainians in the 1986 census. In Gordijew, I. and Koscharsky, H. (eds.). Ukrainian settlement in Australia (Fourth conference). Sydney: School of Modern Languages, Macquarie University, 92.

Szewciw, I. (1990). Ukrajins'ka katolyc'ka cerkva v Avstraliji. In Koscharsky, H. (ed.). Istorija ukrajins'koho poselennja $v$ Avstraliji. Sydney: School of Modern Languages, Macquarie University, 72.

\section{Notes}

Note 1. This figure includes other ethnic groups, members of which were born in Ukraine and also the descendents of those who settled in Australia and regard themselves as Ukrainians.

Note 2. www.abs.gov.au accessed 24/5/2008.

Note 3. The Foundation Director for the Centre, Emeritus Professor Michael Clyne, is one of the most eminent Australian scholars in this field. 


\title{
The Theoretical Quandary of Subjectivity: An Intellectual Historical Note on the Action Theories of
}

\section{Talcott Parsons and Alfred Schutz}

\author{
Matthew M. Chew \\ Department of Sociology, Hong Kong Baptist University \\ Kowloon Tong, Kowloon, HKSAR, China
}

Tel: 852-3411-7132 Email: mmtchew@hkbu.edu.hk

\begin{abstract}
The quandary of subjectivity - how to square the irreducible qualities of the subjectivity category with the need for objective accessibility and scientific universality — was raised by Max Weber in his action theory. Talcott Parsons and Alfred Schutz, the most prominent action theorists after Weber, are said to have dealt with the quandary in very different ways. This intellectual historical note investigates the two theorists in terms of how they dealt with the subjectivity quandary. I will show that because of their different intellectual backgrounds, they mobilized different intellectual tools in the face of the quandary. But their differences are not as significant as assumed. Additionally, their difference cannot be adequately summarized as that of a phenomenological subjectivist solution (Schutz) versus a scientistic objectivist one (Parsons). I will show that the theoretical weaknesses and outcomes of their theories are in effect not very different. I find that both Schutz and Parsons were limited by a philosophy of consciousness paradigm. Under the paradigm, both tried to deal with the subjectivity quandary by insisting on the primacy of an irreducible subjective category on the one hand and subtly re-molding that subjective category into something accessible to the objective observer on the other. In this theorizing process, Schutz was actually pressured to weaken the subjective category almost as much as Parson did. Both ended up failing to square the irreducible qualities of the subjectivity category with the need for objective accessibility and scientific universality.
\end{abstract}

Keywords: Action theory, Talcott Parsons, Alfred Schutz, Jürgen Habermas, Max Weber, Subjectivity

\section{Introduction}

Max Weber thinks that "sociology is a science concerning itself with the interpretive understanding of social action" and wish to establish sociological knowledge on the grounds of an action theory (Weber, 1987: 4) (Note 1). If action is the object of sociological inquiry, sociology cannot avoid investigating the creator of that object, the human actor. In Weber's definition, an actor's behavior becomes an action insofar as the actor attaches a subjective meaning to her behavior (Weber, 1987: 4). Therefore sociology has to deal with a dimension of knowledge that is not problematized in the natural sciences: subjectivity.

In order to gain knowledge of an actor's subjective meanings, social scientists cannot rely on observation alone as natural scientists do, but also on Verstehen. At the same time, as a science, sociology should also produce explanations which are objectively verifiable and adopt research methods that are objectively reproducible. In the attempt to reconcile scientific objectivity with the subjective qualities of action, Weber develops the concept 'ideal type' and two corresponding postulates of adequacy. However, he has neglected to deal with the problem of possible discrepancy between the subjective meanings that an actor thinks she holds and the objective meanings imputed to the actor by 
scientific observers. This neglect is most salient in his treatment of the concept 'motive,' where he does not theoretical differentiate between the subjective and objective meanings.

A motive is a complex of subjective meaning which seems to the actor himself or to the observer an adequate ground for the conduct in question (Weber, 1987: 11) [italics mine].

This unresolved quandary of subjectivity was left to subsequent theorists of action. Among those who emerged immediately after Weber's generation, the two most prominent action theorists were Alfred Schutz and Talcott Parsons. Both centered on the quandary of subjectivity since in their respective early careers. Schutz, in his first major work, The Phenomenology of the Social World, explicitly calls for a thorough analysis of Weber's concept of subjective meaning (Schutz, 1967: xxxi). In his early major work, The Structure of Social Action, Parsons emphasizes throughout the book that the action schema is inherently subjective (Parsons, 1968: 733).

Given the common interest of Parsons and Schutz in action theory and its subjectivity problematic, it is surprising that they appear to develop very different theories and methodologies. Schutz and Parsons had a series of debates in 1941. Schutz accuses Parsons of being not sufficiently radical in asserting the subjective point of view of the actor in a voluntaristic action frame of reference, while Parsons charged Schutz of going outside the valid confines of science in examining the "ontological reality [of] what a concrete real actor 'really' experiences" (Parsons and Schutz, 1978: 88). While it is generally agreed that their antagonism is partly caused by their misunderstanding of each other's theory (especially on Parson's part), contemporary commentators on Schutz and Parsons still usually stress their differences rather than commonalities (Coser, 1979; Natanson, 1978).

These commentaries do not acknowledge the theoretical commonalities between the two figures, commonalities that would become apparent once they are contrasted with action theories launched from a different philosophical paradigm, such as that of Jürgen Habermas. They do not explain why the two diverged from each other despite their fundamental endorsement of Weber's action theory. This intellectual historical note investigates how the two theorists faced and dealt with the theoretical quandary of subjectivity. I will show that because of their different intellectual backgrounds, they mobilized different intellectual tools in the face of the quandary. But their differences cannot be adequately summarized as that of a phenomenological subjectivist solution (Schutz) versus a scientistic objectivist one (Parsons). In contrary to other commentators, I will show that the theoretical weaknesses and outcomes of their theories are in effect not very different. Both Schutz and Parsons were limited by a philosophy of consciousness paradigm. Under the paradigm, both tried to deal with the subjectivity quandary by insisting on the primacy of an irreducible subjective category on the one hand and subtly re-molding that subjective category into something accessible to the objective observer on the other. In this theorizing process, Schutz was actually pressured to weaken the subjective category almost as much as Parson did. Both ended up failing to square the irreducible qualities of the subjectivity category with the need for objective accessibility and scientific universality.

\section{The subjectivity quandary: Parsons and Schutz approaching it under different intellectual contexts}

The two theorists' different views on the subjectivity quandary can be partly traced to the disparate intellectual circumstances under which they conceive the problematic. I will first examine the background in which Parsons is compelled to take up these problems. Parsons' voluntaristic action theory strives to be a convergence of utilitarian, positivist, and idealist traditions. Parsons specifically wants to avoid the pitfalls of utilitarianism and idealism. Parsons is discontent with the tendency toward emanationism in idealism - although idealism is sound in suggesting the subjective point view's indispensability, its focus on the self expression of the ideal "practically eliminates the condition of action and replaces everything with the subjective category" (Parsons, 1968: 715). But Parsons main critique is reserved for utilitarianism.

The utilitarian dilemma is that either the active agency of the actor in the choice of ends is an independent factor in action, and the end element must be random; or their independence disappears and they are assimilated to the conditions of the situation, that is to elements analyzable in terms of non-subjective categories, principally heredity and environment (Parsons, 1968: 64).

To avoid the dilemma, Parsons on the one hand needs to introduce into his action scheme a subjective category so that human action is not exclusively determined by its situation and normative patterns. On the other hand, Parsons has to 
tackle the problem of randomness of ends. Parsons tries to solve it by introducing another element into his action scheme: the normative pattern. However, the presence of a normative pattern can in potential conflict with the autonomy of the subjective category. The antagonism is exacerbated by Parsons' tendency to conceive of normative patterns as an objectively accessible and readily observable element (in order to reinforce the objectivity of his action scheme). In this way, his methodological need for a subjective category is intertwined with the theoretical design of an intersubjectively given normative pattern that in turn is also inextricably linked to scientific objectivity. The theoretical tension between subjectivity and scientific objectivity is very apparent. Yet because Parsons major concern is to construct "a general system of scientific theory, not methodology and epistemology," he tends to emphasize the objectivity side of his action scheme (Parsons and Schutz, 1978: 65).

In contrary to Parsons, Schutz wishes to establish a "philosophically founded theory of method [that] can exorcise the pseudo-problems of sociology" (Schutz, 1967: xxxii). He explores the intricate epistemological and methodological aspects of action theory through clarifying the ambivalent points regarding subjectivity in Weber's methodology. His foremost concern is to demarcate the subjective category and its operations from the observer and her objectively acquired knowledge of the subject. While he acknowledges the fundamental distinction between subjective and objective meanings and that between the natural and scientific attitudes, Schutz also recognizes the need to develop a universal basis on which scientific objectivity is possible. He thinks that Weber's postulates of adequacy alone are not sufficient. He therefore introduces a pregiven intersubjective base for meaning - the social stock of knowledge. In his last book, The Structure of the Life World, Schutz pays much more attention to the social stock of knowledge, its relationship with the subjective stock of knowledge, and the pregiveness of typification and relevance. But these concepts are potentially incongruent with an emphasis on the autonomy of the subjective category. Consequently, there is a serious tension between subjectivity and scientific objectivity in Schutz as well.

\section{Alfred Schutz's action theory}

Schutz's first theoretical step in constructing his action theory is to develop a theory of the ontological structure of the subjective category. He was originally inspired by Bergson's philosophy of durée and lter on he adopted Husserl's transcendental phenomenology to work out his theory of the transcendental solitary ego. According to Schutz, an actor has a unique internal time consciousness which defies the objective conception of time. The most basic form of existence is the stream of consciousness.

In my stream of consciousness [...] my whole consciousness remains temporally uni-directional and irreversible. I am unaware either of my own growing older or of any difference between present and past (Schutz, 1967: 47).

The ego can, however, uplift itself from the stream and scrutinize the stream from a distance. The act of reflection enables the ego to perceive a section of its past experience stream and at the same time to assigns a meaning to it. This important function of meaning-endowing is explicated by Husserl in terms of 'spontaneous activities' and 'secondary modifications' such as 'retention' and 'reproduction.' These terms refer to the various processes through which the ego emerges from an experience stream, spreads out a cone-like ray of attention, and illuminates from a specific 'here and now' status to a specific part of the undifferentiated stream of experience.

Given the particular characteristics of Schutz and Husserl's transcendental ego, the meanings it constitutes through attentional modifications are variable and ephemeral.

The meaning of a lived experience undergoes modifications depending on the particular kind of attention the Ego gives to that lived experience [...] The meaning [...] is different depending on the moment from which the Ego is observing it (Schutz, 1967: 73-4).

Apart from the attentional ray and the particular 'here and now', schemes of experience are also a crucial determinant of the substance of subjective meaning. These schemes are "meaning contexts which is a configuration of past experiences" of an actor. They are the interpretative tools "essential to the ego as it explicated what it has already lived through" because in fixing a specific meaning to experience, the ego must always "refer back to the schemes on hand" (Schutz, 1967: 82-3). Within an actor's subjective stock of knowledge, however, there are still a variety of different schemes to choose from. The degree of attention an ego bestows upon these schemes affects the choice. Certainly these three factors are interdependent. Their combined outcome is that the scientific observer, from an objective point of view 
and without having identical lived experiences, cannot absolutely accurately know an actor's subjective meaning. Schutz tries to provide a concrete answer to the question that Weber asked in his earliest formulation of the Verstehen thesis.

Consider the 'meaning' which we could dogmatically or prescriptively ascribe to a process of [action]. Was it also the 'meaning' which each of the actual participants in this process consciously ascribe to it (Weber, 1977: 112)?

Schutz attempts to bridge the gap between subjective and objective meanings through several theoretical manoeuvers. The first of them is the presupposition of the alter ego. The alter can be used to circumvent the intersubjective impasse in Husserl's transcendental phenomenology. If, according to Husserl, all reality is constituted by the solitary ego through intentional acts, the other actors in the social world cannot possibly be known to the solitary ego as an alter. The solitary ego has no means to assess the existence of another parallel entity, which is the subjective category of another being. Schutz recognizes that action theory is basically incongruent with transcendental phenomenology in this aspect. Schutz argues that when Weber insists on Verstehen as the method of obtaining social scientific knowledge from an actor, Weber must already be implicitly "presupposing the meaning existence of the other self" and that the actor "does mean something and that [one] can find out what it is just as [one] can find out what the meaning of [one's] own behavior is" (Schutz, 1967: 19-20). Schutz accuses Weber of failing to render these important assumptions explicit. Schutz's presupposition of the parallel alter indeed avoid Weber's problem, but not in a very satisfactory way. It is because the presupposition is incongruent with Schutz phenomenological grounding. He has to emphatically state that the intersubjectivity is a sociological matter rather than a philosophical one in order to hide the atheoretical, abrupt nature of his shift from a solitary subjective basis to an intersubjective analysis.

Nevertheless, the presupposition of the alter is significant in that it allows Schutz to refine his theory of intersubjective understanding processes. Schutz utilizes a theory of appresentation to explicate the processes. He first draws up two subjective categories, the ego and the alter. Then he assigns a field of expression to each of them in which they express signs, symbols, and indications. The alter, knowing that one cannot reach a completely accurate assessment of the meaning behind those expressions, must make two idealizations of the situation in order to proceed with the interpretation. Firstly, the alter has to assume that their standpoints are interchangeable, that is, she was here where I am now and she would experience things from the same perspective (Schutz and Luckmann, 1973:60). Secondly, the alter must also presuppose that their relevance structures are congruent with each other, "as if we had experienced in an identical way, and had explicated the Objects in our reach" (Schutz and Luckmann, 1973:60). Together, the two idealizations form what Schutz calls 'the general thesis of the reciprocity of perspectives.'

Schutz's second theoretical device of dealing with the subjectivity quandary is the ideal type. He does not merely reaffirm Weber's original formulation; he refines the concept. The 'course-of-action type' and the 'personal ideal type' are differentiated from the overall concept 'ideal type of human behavior.'

The course-of-action type can be considered quite independently as a purely objective context of meaning [...]. [For the personal ideal type], I imagine the corresponding subjective meaning context which would be in his [the actor's] mind, the subjective contexts that would have to be adequate to the objective context already defined (Schutz, 1967: 187-8).

The personal ideal type is thus derived from the course-of-action type. The ideal type constructed in this way mitigates meaning's dependence on a particular here and now, since "these types 'lives' in a never-never temporal dimension" and are "absolutely anonymous" (Schutz, 1967: 191).

Schutz's aim here is to design an ideal type which can act as a 'puppet' for the concrete actor. The subjective meaning of this puppet is exactly the one assigned objectively by the observer. Consequently, the question of discrepant subjective and objective meaning becomes the problem of choice of ideal types. Schutz then sets out to refine Weber's two postulates of adequacy for ideal type construction. He contends that causal adequacy and adequacy on the level of incoming are just two sides of the same coin. As Schutz push the analysis a further step back, each of the two postulates is satisfied if and only if the observer's construction of type is congruent with her own subjective stock of knowledge. It is because adequacy on the ideal of meaning is, after all, based merely on the observer's objective approximation of the subjective meaning of the actor. Causal adequacy, on the other hand, is the observer's knowledge of "that objective context of meaning which is social science itself" (Schutz, 1967: 230). Schutz's postulate hence becomes: "the type must be sufficient to explain the action without contradicting previous experience" (Schutz, 1967: 236). 
The third theoretical manoeuver through which Schutz deals with the subjectivity quandary is the concept 'social stock of knowledge.' This is an original contribution of Schutz. Meanings will be more universally recognized, communication will be more accurate, and interpretation of expressions will reach the intended meaning more closely if subjective stocks of knowledge - both among the observers themselves and between the actor and observer - can be related more closely to one another substantively. In an initial formulation, Schutz introduces a pregiven and intersubjective basis for such a purpose.

There is only one external world, the public world, and it is given equally to all of us. Therefore, every act of mine refers back to the same meaning-endowing act of yours with respect to the same world (Schutz, 1967: 32).

In the Collected Papers, Schutz explains the degree of sharing and the commonality of knowledge to all actors in any social world.

Only a very small part of any knowledge of the world originates within my personal experience. The greater part is socially derived (Schutz, 1962: 13).

The fullest account of the social character of subjective stocks of knowledge is given in Structures of the Life World (Note 2). Schutz first clarifies that "no element of knowledge can be traced to any sort of primordial experience," but one "always encounters prior experience in which an already determined [...] stock of knowledge must be conjoined" (Schutz and Luckmann, 1973: 119). He explains that 'types,' which make up the main body of a stock of knowledge, are not an independent subjective construct. It is because "every type is a meaning context 'established' in lifeworldly experiences [and] sedimented in prior experiences" (Schutz and Luckmann, 1973: 230). Even the types that one creates anew must always be based on pregiven types. The relevance structures at the base of a stock by knowledge are equally intersubjective.

From the beginning, the subjective structures of relevances are developed in situations which are intersubjective [...] [; the sedimentation of specific elements in the subjective stock of knowledge is socially conditioned (Schutz and Luckmann, 1973: 243).

In regard to the methodologically crucial element of autonomous subjectivity, Schutz becomes quite ambivalent. Although he repeatedly maintains that it exists, he also thinks that

The independently acquired elements of knowledge are also embedded in the whole context of an extensively 'socialized' subjective stock of knowledge [...] Consequently, one cannot actually speak of absolutely 'independent' elements in the [subjective] stock of knowledge (Schutz and Luckmann, 1973: 262).

When this assumption of intersubjectivity is juxtaposed with Schutz's analysis of the solitary ego, the tension between objectivity and subjectivity is even clearer. In the analysis, the solitary ego is an absolutely independent entity which produces an "attending ray [that] is not separate from the Ego itself" (Schutz, 1967: 73). But in his analysis of the intersubjective, Schutz introduces a pregiven social stock of knowledge. Its boundary limits the direction and depth of the kind of attention an ego can possibly make. Firstly, it is because the availability of interpretive schemes, which are so essential to the mechanism of attentional modification, is limited by social stocks of knowledge. An actor cannot interpret her experience in a way that social stocks of knowledge do not endorse or supply types with. Secondly, the whole process of attention an ego gives to experience and knowledge depends preponderantly on relevance structures.

[Relevance structures] can make an experience problematic, [...] determine the direction of the process of explication, [...] cause the conclusion on discontinuance of the process, [...] bring about application of the sedimented element of knowledge in mastery of new actually present situations, [...] [and] are prominent in consciousness' reflective grip on an already constituted element of knowledge (Schutz and Luckmann, 1973: 228).

Hence, the only completely socially independent element left is the specific 'here and now.' If the subjective category still retains this unpredictable element, Schutz's demarcation between the objective meaning and the transient and that between variable and inaccessible subjective meaning still stand. However, the social stock of knowledge has encroached upon the ego to such an extent that the ego has become a nominal and strictly transcendental entity without any substance. This seriously undermines Schutz's original intention (which is shown in the citation below) to assign to the subjective category a very active and dynamic role in the social world. 
We no longer naively accept the social world [...] as ready-made and meaningful beyond all doubt, but undertake to study the process of idealizing and formalizing [and] the genesis of meaning (Schutz, 1978: 52).

\section{Talcott Parsons' action theory}

Parsons' initial formulation of the subjective category resembles the final and devitalized version of Schutz's transcendental ego resemble. Parsons stresses that the unit act is subjective in the particular sense that "it refers to events as they appear from the point of view of the actor whose action is being analyzed" (Parsons, 1968: 46). The subjective category contains elements that are completely independent of knowledge.

The basic tenet of the voluntaristic [action theory] is that neither positively nor negatively does the methodological scheme of scientific knowledge exhausts the significant subjective elements of action (Parsons, 1968: 81).

He describes the nature of the subjective category as a 'state of mind.' However, the concept 'state of mind' is operational in the sense that it refers to a subjective entity "considerably broader than that of consciousness in common sense terms" (Parsons, 1938: 7). Beyond that, "it is not necessary to make any further ontological assumptions as to the ultimate nature of this entity" (Parsons, 1938: 7). Parsons is content with the subjective category being an inert entity that "is simply the unitary referent of certain possible statements of fact" (Parsons and Schutz, 1978: 88). It merely represents a point of view to which action can be imputed - for it is methodologically required that action must have a subject-actor as its origin, in the same way that the movement of a mass in classical mechanics must have a Cartesian origin as a point of reference. Although Parsons considers the subjective category significant, his theory still only gives it a formal and nominal existence. The quality of the subjective category can be further examined in his general formula of the voluntaristic unit act.

$$
A=S(T, t, i, r)+E(T, t, i, i 2, r)+N(T, t, i, i 2, r) \text { (Parsons, 1968: 82). }
$$

Action $\mathrm{A}$ is composed of the situation $\mathrm{S}$, the end $\mathrm{E}$ and the standard relating the situation and the end, N. Parsons explains that all three elements of action exist and are viewed subjectively in the actor's terms. $\mathrm{T}$ and $\mathrm{t}$ represent the actor's scientific knowledge and knowledge which is fallacious respectively; i and i2 refer to the normative elements existing in the actor's terms and in symbolic expression respectively. Without the presence of a subjective category, all these variables and the three functions which they make up are inconceivable. The crucial part is the variable $r$. It represents the element varying at random relative to those formulated as $\mathrm{T}$ and $\mathrm{t}$. However, it leads a very ambivalent presence in the formula. On the one hand, Parsons recognizes that the subjective category necessarily contains an objectively unpredictable and incomprehensible element, and that the end, situation, and normative patterns are partly dependent on this element, as the $r$ in the S, E and N functions shows. On this point, Parsons converges with Schutz's notion of the inaccessible subjective meaning of action. On the other hand, Parsons has professed to avoid the randomness of ends and normative patterns. Since Parsons is not very concerned with the ontology and capability of the subjective category in the first place, the theoretical tension led Parsons to play down the unpredictability of the subjective point of view and to further affirm the passiveness of the subjective category.

Schutz's transcendental ego varying with respect to a here and now corresponds to Parsons' random 'state of mind.' Schutz's subjective and social stocks of knowledge also find their functional counterpart in Parsons' 'normative pattern.' Parsons explains that a normative element must 'be held to manifest or otherwise involve a sentiment attributable to one or more actors that something is an end itself" (Parsons, 1968: 75). However, normative elements are by definition external to the subjective category. It is only a maxim that prescribes the end of the actor; it has no absolute binding force. The actor has to contribute her effort to achieve the normative end. This element of effort breathes a bit of initiative and substance into the subjective category. Parsons also stresses its importance when he regards effort (or 'orientation' in his later terminology) as the crucial and single "relating factor between the normative and the conditional element of action" (Parsons, 1968: 719). However, similar to the fate of Schutz's subjective category, Parsons' originally subjective notion of effort is subsequently made to be dependent on pregiven and intersubjective normative elements due to the requirement of scientific objectivity.

That the issue of normative elements is crucial to scientific objectivity can be clarified by referring to the general formula again. Normative elements i and i2 are present in the functions of all three basic elements of action. Parsons assumes that the variables $\mathrm{T}$ and $\mathrm{t}$ are by definition judgable from an absolute, universal and objective standard (because 
they are related to scientific knowledge). The actor and the observer should have an identical point of view when dealing with these variables. Hence, if it can be proved that normative elements are similar from the perspectives of the actor and observer, the objectivity of the meaning is established. Similar to Schutz's connecting of the subjective to social stocks of knowledge, Parsons also brings external normative elements into the actor: the process of internalization.

Parsons adopts the Freudian perspective that morals, rules, and norms of a culture constitute and are assimilated to the superego of an individual's consciousness. He also supplements this perspective with George Herbert Mead's symbolic interactionist approach. To Mead, socialization is the process of learning to take and make appropriate roles; these roles are in turn prescribed by the situation, tradition, and other actors in the social world. Parsons in his subsequent works introduces his four pattern variables to assess the actor's normative pattern. In playing a certain role, the actor always strives to act according to the specific values of pattern variables that culture has preordained.

However, Parsons does not rigidly take objective cultural norms as the equivalent of internalized norms. He allows room for a certain degree of randomness which he promises in his general formula. As Jeffrey Alexander rightly points out that for Parsons,

first, in any given situation an "ordered pattern" is not all of one piece, but represents, rather variation within an acceptable image, [...] second, even when personalities "have been exposed to the same experience as other persons", individual idiosyncrasies and accident of birth will create "influential sources of variation" (Alexander, 1983: 42).

Nevertheless, the number of roles, normative elements, and moral imperatives are still limited and they are not easily created anew. It may be valid for Parsons to claim on the basis of this limited variation that an actor "does not merely react to its stimuli" of the situation and normative pattern (Parsons, 1938: 9). But it does not substantiate Parsons' claim that the actor in an action actively "take advantage of the situation to further this [...] normative tendencies" (Parsons, 1938: 9). Variation seems to be merely a de facto phenomena rather than subjective effort. The actor's choice of normative pattern is still determined, if not by the stock available in a culture, then by personal idiosyncrasies and personally unique conditions of socialization. But they are precisely the non-subjective categories of heredity and environment that Parsons wants to de-emphasize. 'Effort' in this scheme lacks a basis for operation; it becomes less of a subjective motivation than intersubjective channeling.

Beside normative patterns, another theoretical device that Parsons adopts to install scientific objectivity is a universal conceptual scheme. He argues that both the observer and the actor utilize the same tools to interpret an action.

[The actor and the observer] act as well as think in "terms of a conceptual scheme" [...]. They also appraise or evaluate in terms of a conceptual scheme in the retrospective understanding of their own and other's action, [...] in terms of the same set of categories in the Kantian sense (Parsons, 1978: 123).

The ineffectiveness of this argument can be shown in a comparison with Schutz. Schutz could actually accept Parsons' absolute and universal 'conceptual scheme' concept without altering any part of his own theory. Husserl originally hopes to comprehend the essence of consciousness through the epoché. When Schutz adopts Husserl's transcendental phenomenology, Schutz avows that sociological inquiry should not deal with philosophical problems and even reverses the epoché to render the natural attitude a subject of investigation. It does not matter to Schutz whether the universal elements of consciousness are Kantian categories or not. Schutz can rely on additional tools for interpretation, including the ideal type, the meaning context, and the stock of knowledge. Apart from Kantian categories, Parsons does not seem to regard any additional conceptual tools as necessary. It is rightly pointed out that

Parsons was not conversant with phenomenological psychology, [...] [but] pitted his Neo-Kantian position against Schutz, denying that there is any access to human experiences except by mediation of a conceptual scheme (Wagner, Smith, and Smith, 1979: 686).

As Parsons himself has noted, the epistemological basis of his action theory is not as meticulously constructed as its theoretical basis. This lack of meticulousness has led to a fundamental difference between him and Schutz — Parsons' under-theorization of motivational Verstehen and the ideal type. This under-theorization in turn leads to a less skeptical treatment of scientific objectivity. 


\section{Identifying the substantive differences between the two theorists' action theories}

Schutz criticizes Weber's distinction between actual and motivational Verstehen. In both kinds of Verstehen, the knowledge the observer has on the actor is derived from prior meaning the observer attaches to the actor, and from not the subjective meaning of the actor herself. The real distinction lies in the epistemological basis of the two kinds of Verstehen. Actual Verstehen is the direct understanding that takes place where "the lived experiences of the other are occurring simultaneously with my own objective interpretations of his words and gestures" (Schutz, 1967: 173). Motivational Verstehen is "not tied to the world of directly experienced social reality but starts out on the basis of an established objective meaning as an indication of the existence of a subjective meaning" (Schutz, 1967: 30-1). It cannot work on the basis of observation alone, but requires a certain amount of knowledge of the actor's past and future. The more accurate and abundant this knowledge is, "a higher degree of scientific clarity and exactitude is attainable in motivational understanding" (Schutz, 1967: 31). In short, motivational Verstehen is analytically distinct from actual Verstehen because it involves a hermeneutical process.

Parsons also sees Weber's distinction of the two types of Verstehen problematic. He regards Weber's distinction as a 'pragmatic' one, because he thinks that

We understand things aktuell insofar as, in terms of everyday experience, they are evident from the mere fact of being observed [...]. Motivationsmassiges Verstehen is the understanding of the element of motivation that is not evident in the particular concrete observation but remains problematical (Parsons, 1968: 636).

Parsons thinks that Weber misses the more important demarcation: the demarcation between motivations as processes in time and those as atemporal meaning complexes. In the former, "meanings cannot be divorced from the intrinsic relationship of ends, means and conditions" (Parsons, 1968: 636). Investigation of this kind of motivation requires hermeneutics because means, ends, and conditions are from the subjective point of view. Parsons tends to circumvent this type of motivation by that of the interpretation of atemporal meaning complexes, which demands observation much more than hermeneutical interpretation.

The real things or events that may be observed may be significant only as symbols with no intrinsic significance of their concrete properties. In this case, Verstehen is necessarily limited to the meanings of the symbols as such without reference to any intrinsic relationship in the real world (Parsons, 1968: 637).

Parsons claims that this type of Verstehen, which is in abstraction from motivation, "plays an important part in Weber's own empirical research" (Parsons, 1968: 637). However, Weber had never intended to give up motivational Verstehen. Parsons is in effect shifting Weber's emphasis from the interpretation of what the actor means to what culture and normative patterns mean. This shift is especially salient in Parsons later works, as Roy Fitzhenry (1986: 156-7) have also noticed.

Parsons began with a partial version of [...] Verstehen, [...] about 1950, a strong preference for the casual role of external symbolic system of action emerged, with the consequent redefinition of motivation-processual Verstehen as a necessary but secondary investigation [...] The practical consequence of this was that Parsons never subsequently refined the concept of motivational Verstehen .

Besides the jettison of motivational Verstehen, Parsons' abandonment of the ideal type contributes just as much to his inability to account for the discrepancy between objective and subjective points of views, and hence also his unsatisfactory treatment of the quandary of subjectivity. In fact, the concepts of ideal type and motivational Verstehen are so closely related theoretically that giving up one easily leads to abandoning the other. Parsons advocates analytical realism and ambitiously attempts to build a generalized theory of action which is able to describe any possible variants and permutations of social action. He is against historicist 'fictionalism,' which he takes as epitomized by Weber's use of ideal types. One of Parsons' critiques to the ideal type is convincing.

The ideal type, being a universal, does not involve a combination of specific values, but it does involve a fixed set of relations between the values of the analytical elements. They are, however, often independently variable beyond the range permitted by the definition of types. Hence, [there is] an element of rigidity (Parsons, 1968: 621).

Schutz's concession to this critique can be seen in a subtle reformulation of his theory. He states in reaction to Parsons that action can be reduced to a typical unit act, with the actor's "typical motive, including the reference to typical 
situation, typical ends, typical means, etc" (Schutz, 1978: 52). Nonetheless, apart from this tenable critique of the ideal type, Parsons' analytical and realistic orientation is exactly what Weber had intentionally avoided. Weber had strongly argued against it in a debate between him as the representative of the Historical School tradition and Carl Menger of the Marginal Utility School. Menger distinguishes sharply between 'realistic theory,' which he characterizes as a deductive theory based upon mental constructs such as ideal types, and 'exact theory,' which he characterizes as an inductive theory based on historical data. Weber refuted such a demarcation and his three supporting arguments can be partly directed against Parsons.

Firstly, Weber contends that the social world, the subject of social science, is meaningful to the scientific observer in a way in which the natural world, the subject of natural science, is not. This difference is most clearly elaborated by Anthony Giddens.

The natural world $[\ldots]$ is not 'meaningful'; the meanings it has are introduced by men as a consequence of their endeavors to understand it. [...] Social life-- of which these endeavors are a part-- is produced by its component actors precisely in terms of their active constitution and reconstitution of frames of meaning whereby they organize their experience (Giddens, 1976: 79).

Due to this difference, natural scientific investigation involves only one level of hermeneutical-interpretive understanding. But the process of social scientific investigation has two layers of interpretation. Due to this 'double hermeneutics,' the historical data with which exact theory starts cannot be but ideal typical constructs formed by mental conceptualization. Weber argues that "the only exact form of knowledge - the formulation of immediately and intuitively evident laws - is however at the same time the only one which offers access to events which have not been observed" (Weber, 1949: 87). Since Parsons himself has also emphasized the hermeneutical nature of social science, he should not have abandoned the ideal type in such a cavalier way.

Weber's second objection to Menger is that theoretical systems cannot capture the totality of reality and history. Equipped with Alfred N. Whitehead's philosophy of science, Parsons has a more sophisticated philosophical background compared to Menger, but he is similar to Menger in the attempt to construct a comprehensive general theory. Parsons leaves his theory empirically open and logically closed, but Weber would have argued that a theory should be open in both aspects. It is because Weber recognizes

the methodological impossibility of supplanting the historical knowledge of reality by the formulation of laws or, vice versa, of constructing 'laws,' [...] through the mere juxtaposition of historical observations (Weber, 1949: 87).

Weber's ideal types are designed historical specifically to explain the era of Western capitalism. He contends that if theory is capable of capturing history, it will hence be meaningless to investigate into any individual historical case once the general theory is built. Social science would then be equal to the study of history.

Weber's third contention is that both exact theories and realistic ones are inductive in nature. Menger has not considered that the construction of ideal type, prior to deduction, already involves inductive reasoning. The observer also has to gather enough data to satisfy the postulates of adequacy before she can construct a valid ideal type. To Weber, both exact social sciences and realistic ones are not exact. Knowledge is based on a one-sided assessment of reality on the scientific observer's part. Failure to acknowledge this 'inexact' nature of social science results in the tendency towards reification of theoretical knowledge (the objective meaning of the observer) into concrete reality (the subjective meaning of the actor). This tendency is also present in the heir to the Marginal Utility School, modern economics. Although Parsons repeatedly stresses the importance of distinguishing the concrete from the analytic, his abandonment of the ideal type leaves his theory vulnerable to the accusation of reification.

Parsons gives up the ideal type without attempting to refute the Weber's three arguments. He also abandons motivational Verstehen. Without these two important tools for social scientific interpretation, what he takes as the close connection between the subjective and objective points of view is not as fully explicated as in Schutz. On the whole, Parsons has tried to assert scientific objectivity more than to meticulously build a theoretical basis for it. This problem of Parsons' stems ultimately from his shift of scholarly interest from social integration to functional integration, that is, from action theory to cybernetics and systems theory. 
Although Schutz was more meticulous in building a theoretical base for scientific objectivity, he under-emphasized and under-theorized the issue of consensus as much as Parsons did. Giddens points out that "for Schutz's social world, like that of Parsons, is largely a consensual one" and concludes that they "depart in a substantial way from Max Weber" (Giddens, 1979: 685). Schutz regards intersubjective meaning and social stocks of knowledge in the lifeworld as "taken for granted until further notice." Parsons takes normative elements and patterns as pregivens in culture and then designates them as the subject matter of anthropology. Both theorists do not acknowledge the need to directly investigate the realm of pre-existing intersubjective meanings. Weber explains that "an order may be established in one of two ways: by voluntary argument or by being imposed and acquiesced" (Weber, 1978: 50). Both Parsons and Schutz conceive of an imposed, preordained order rather than a voluntaristic one in the social world. They do not envision a lifeworld bound by intersubjectively constructed consensus, a step that Habermas subsequently took in his action theory.

In regard to the subjectivity side of the quandary, Parsons is actually more theoretically comprehensive than Schutz in some aspects. Before going into that, it is essential to emphasize that Parsons is not much less mindful of the subjective category than Schutz. Both persistently adhere to the concept. Some critics of Parsons have mistakenly accuses him of giving up the subjective category in the later works.

Contrary to the view held by the author in The Structure of Social Action, it now appears that [the study of action from the point of view of actor] is not essential to the frame of reference of actor in its most elementary form. It is, however, necessarily involved at the level of elaboration of system of action at which culture, that is shared symbolic patterns, becomes involved (Parsons, 1951: 543, quoted in Fitzhenry, 1986: 154).

Parsons does not treat the subjective category the same way he treats motivational Verstehen. What Parsons means by the most elementary form is that it is possible only when the scientist "keeps the elaboration of the theory of action to pre-symbolic, precultural levels, [which] is essentially what Professor B.F. Skinner does" (Parsons, 1951: 544).

Parsons' treatment of the subjective category as a mere point of reference has paradoxically given him some advantages over Schutz's subjective category as a transcendental ego. Schutz maintains a strict distinction between action and behavior - in the sense that action is conscious, with which the ego must consciously create a project of the act before the action, and in the sense that behavior is not conscious, with which the ego could stay immersed in the stream of consciousness without any attempt of reflection. However, Weber's formulation of action includes affectual action, which is "determined by the actor's specific affects and feeling states," and traditional action, which is "determined by ingrained habituation" (Weber, 1978: 25). Schutz's scheme of action inevitably excludes these two types of action.

Strictly traditional behavior [...] lies very close to the borderline of what can justifiably be called meaningfully oriented action, and indeed often on the other side [...]. Purely affectual behavior also [...] often goes over the line (Weber, 1978: 25).

While Schutz criticizes the vagueness of Weber's notions of action and behavior, he admits that rational action is not the only type of action which needs to be investigated. But his action theory is not capable of accounting for the two types of non-rational action. He is ambivalent about how non-rational action is carried out under the auspices of the transcendental ego and whether it involves an act of attentional modification.

For Parsons, however, the subjective category is only a point of reference. The notion of effort, unlike attentional acts of reflection, does not discriminate traditional and affectual actions from other action types because affectual actions also necessarily involve normative patterns. Normative patterns are by Parsons' definition traditionally given. Parsons also adopts Freud's later argument that even the id has a social dimension. A rational action requires effort in the same way that non-rational action does

Only a certain aspect of the concrete relations of the organism-actor [...] [is] of interest to the theory of action; this is the aspect we call 'action' or 'behavior' (Parsons, 1951: 541).

Parsons' definition of action does not need to differentiate between kinds of action through criteria such as consciousness and rationality. Weber's equivocation concerning non-rational action hence turns into an insignificant problem in Parsons' voluntaristic frame of reference. 
The action theories of Parsons and Schutz have their own strengths and weaknesses. But in both theories, the subjective category is eventually reduced to a nominal existence. Unfortunately, despite their weakening of the subjective category, their attempt to establish scientific objectivity is still unsuccessful. A main reason that Parsons failed is his neglect of hermeneutical interpretation. By positing an unbridgeable gap between subjective and objective meanings and then adopting the ideal type as a theoretical compromise, Schutz in effect supports a relativistic view of social science as strongly as scientific objectivity.

\section{An alternative philosophical paradigm as a solution to the quandary: Jürgen Habermas' action theory}

An important attempt to solve the subjectivity quandary is to shift the philosophical starting point of action theory from the philosophy of consciousness to linguistic philosophy. Schutz begins his analysis of action with the transcendental solitary ego of Husserl's phenomenology. Parsons initiates his action scheme on the 'state of mind' of the actor. For them, the subjective point of view and its meaning compose the social reality that science aims to decipher. Habermas considers the consciousness paradigm problematic.

Analytical theory treats the venerable problems of the preKantian philosophy of consciousness in a new constructive, without pushing through to the basic action of a sociological theory of action [...] from a sociological point of view, it makes sense to begin with communicative action (Habermas, 1984: 274).

With a linguistic philosophical paradigm, the question of the subjective category is sidelined. The relationship of interest is that between a speaker and the hearer rather than that between a subject and the observer. The action theory of Parsons and Schutz first presupposes an isolated subjective category. Then the observer comes into the scene and tries to interpret the meaning of the subject's action. However, the meanings that the actor uses in carrying out and giving meaning to his action are itself intersubjectively shared and derived. This is why the assumption of an isolated category is problematical in the first place. Habermas' action theory starts with the speech act, which itself is the meaning to be interpreted. Meaning and action is at any point of the analysis is intersubjective. The tension between the subjective category and the intersubjective ground can hence be circumvented.

\section{Conclusion}

The previous analysis has showed that both Parsons and Schutz encountered the quandary of having to reconcile the subjective category with scientific objectivity, and that they have chosen different means to solve the problem. Despite their fundamentally different treatments of the hermeneutical nature of Verstehen, the ideal type, and non-rational actions, their efforts are similar in many aspects. Lewis A. Coser (1979: 681) thinks that it is "their differences on the status of subjectivity in the analysis of social action" that have "prevent[ed] any true meeting of minds." But actually both theorists ended up not granting subjectivity a robust status in their systems: while both emphasized the subjective category initially, they were eventually forced in different ways to strip away its substance and to render it nominal. It is more accurate to interpret their miscommunication in terms of their very different intellectual backgrounds than their not-very-different solutions to the quandary of subjectivity.

Maurice Natanson's contrast between Parsons and Schutz is also problematic. He characterizes the two sociologists' differences in terms of four issues: their different responses to the "Weberian suggestion [of] giving sociology a solid foundation by starting from how methodology could grasp [the] texture of social action," their different solutions to the "Cartesian dilemma [of] constructing an objective social science in starting from subjective experience structures," their different treatment of the "Kantian problem" of using a Kantian schemata of understanding to conceptualize an actor's actions, and the 'Schutz-Parsons divide' of relating between the everyday lifeworld and the scientist's world (Natanson 1978: xx-xxi). The previous analysis has shown that Schutz can actually accommodate Parsons' Kantian categories in his scheme without any difficulty. As regards Natason's 'Schutz-Parsons divide,' although Schutz demarcate the everyday lifeworld of actors from the observer much more sharply than Parsons does, both ended up privileging the external observer. Neither does the 'Cartesian dilemma' polarize their theories. Even though Parsons is less concerned with the genesis of objective meaning structure from the actor-subject than Schutz, both of them subsequently strip away all independent substances from the subjective category and presuppose an intersubjectively pregiven structure of meaning that facilitates consensus. As Habermas' action theory shows, the subjectivity quandary cannot be avoided unless one abandons the philosophy of consciousness paradigm. 


\section{References}

Alexander, J. (1983). The Modern Reconstruction of Classical Thought, Vol. 4. Berkeley and Los Angeles: University of California Press.

Coser, L. A. (1979). A dialogue of the deaf. Contemporary Sociology, 8(5), 680-682.

Fitzhenry, R. (1986). Parsons, Schutz and the problem of Verstehen. In R. Holton and B. Turner (Eds.), Talcott Parsons on Economy and Society. London and New York: Routledge, Kegan and Paul.

Giddens, A. (1979). Schutz and Parsons: problems of meaning and subjectivity. Contemporary Sociology, 8(5), $682-685$.

(1976). New Rules of Sociological Method: A Positive Critique of Interpretive Sociologies. New York: Basic

Books.

Habermas, J. (1984). The Theory of Communicative Action, Vol. 1. T. McCarthy (Trnl.). Boston: Beacon Press.

Natanson, M. (1978). Foreword. In R. Grathoff (Ed.), The Theory of Social Action. Bloomington: Indiana University Press.

Parsons, T. (1987). A 1974 retrospective perspective. In R. Grathoff (Ed.), The Theory of Social Action. Bloomington: Indiana University Press.

- (1968) The Structure of Social Action, Vol. $1 \& 2$. New York: The Free Press.

(1951). The Social System. New York: The Free Press.

(1938). Actor, situation and normative patterns: an essay in the theory of social action. unpublished.

Parsons, T. \& E. Shils, et al., (1954). Toward a General Theory of Action. Harvard University Press.

Parsons, T. \& Schutz, A. (1978). The Schutz-Parsons letters: January 16, 1941 to April 21, 1941. In R. Grathoff (Ed.), The Theory of Social Action. Bloomington: Indiana University Press.

Schutz, A. (1978). Inquiry into the structure of social action. In R. Grathoff (Ed.), The Theory of Social Action. Bloomington: Indiana University Press.

- (1967). The Phenomenology of the Social World. In G. Walsh \& F. Lehnert (Trnls.). Evanston: Northwestern University Press.

(1962). Collected Papers, Vol. 1. M Natanson (Ed.). The Hague, Netherlands,

Schutz, A. \& Luckmann, T. (1973). Structures of the Life-world. R. M. Zaner. and T. H. Engelhardt. Jr. (Trnls.). Evanston: Northwestern University Press.

Wagner, H. R, H. Smith, \& W. Smith. (1979). Theory of action and sociology of the life-world. Contemporary Sociology, 8(5), 685-687.

Weber, M. (1978). Economy and Society, Vol. 1. G. Roth \& C. Wittich (Eds.). Berkeley and Los Angeles: University of California Press. (1977). Critique of Stammler. G. Oakes (Trnl.). New York: The Free Press.

(1949). The Methodology of the Social Sciences. E. A. Shils \& H. Finch (Trnls.). Illinois: The Free Press.

\section{Notes}

Note 1 . I would like to thank the anonymous reviewer for her very valuable comments.

Note 2. The most elaborate discussion of social stock of knowledge is found in Chapter Four of the book, which was not in Schutz's original draft. Thomas Luckmann felt that this topic needs to be elaborated and added the chapter by himself. Although it is Luckmann's extension, the framework, the main ideas and the tendency were already present in Schutz draft. 


\title{
Review of European Studies
}

\section{Comparison of the Convertible Bond Market Development in China and Europe and the Enlightenment}

\author{
Shengchun Zhu \\ Shenzhen Graduate School, Harbin Institute of Technology \\ Shenzhen 518000, China \\ Tel: 86-755-2600-8608 E-mail: zsc22@126.com
}

\begin{abstract}
As a financing tool with the characteristics of debt, stock, and option, convertible bonds have achieved a great development in Europe. China's convertible bonds market faces a series of problems, including public issuing, policy support for traditional industries, absence of short mechanism, and convergence of product design. China must summarize experiences from European market, apply support policies, and build a convertible market with sustainable development by means of perfecting the credit grading system, releasing the market entrance restrictions, encouraging innovations in product design and issuing ways.
\end{abstract}

Keywords: Convertible bond, Product innovation, Credit grading, Policy support

Convertible corporate bond, namely convertible bond for short, is issued in form of bond by legal procedures, and can be converted into stock under certain conditions. As one of main financial tools in world capital market, convertible bond has already gained fast development in USA and Japan. Chinese and European enterprises have started to use this financial tool since $90 \mathrm{~s}$ in $20^{\text {th }}$ century. Therefore, to summarize and compare the development of convertible bond in China and Europe is meaningful in practice.

\section{Compare the development of convertible bond market in China and Europe}

Europe is always one of main bond market in the world. Compared with USA and Japan, European investors emphasize on stable return. The coupon rate of convertible bond is lower than that of other bonds, which stops its development in Europe in a sense. Till early $80 \mathrm{~s}$ in $20^{\text {th }}$ century, American and Japanese enterprises begin to realize financing by issuing convertible bond in European bond market. Afterwards, England enterprises start this financing channel. But enterprises in Europe and China begin to use convertible bond as a financing tool in $90 \mathrm{~s}$ in $20^{\text {th }}$ century. Dortmunder Verein issues 390,000 convertible bonds for the first time, which pioneers the financing by convertible bonds in Europe. The deepening integration of European economy makes convertible bonds circulate in EU market. The issuer of convertible bonds can get considerable capitals in a short period, which drives the prosperity of European convertible bonds. In 1997, the market scale of convertible bonds in Europe is 65.6 billion US dollars, accounting for $16 \%$ of global market shares. In 1999, the scale reaches 124 billion US dollars, accounting for $26.22 \%$ of global market shares. In 2000 , the percentage reaches $31 \%$. European convertible bond market becomes the No.2 in the world. As a most free financial market in the world, Europe has already become one of most important convertible bond market in the world, no matter what it is evaluated by the new bond circulation, the market depth, or the degree of specialization. European convertible bond market mainly centers in France, German, and Switzerland. Especially, France has issued the great amount of convertible bonds in Europe.

China's capital market starts too late. Its development is no more than 20 years. In China, the capital market is a product 
of financial innovation. But convertible bond almost accompanies and victims the growth of A share market. In 1992, Shenzhen Baoan Group issues the first A-share convertible bond, which signalizes the birth of convertible bond in China. In 1993, China Textile Machinery and CSG holding were formally approved to issue convertible bonds in foreign countries, which is the fist of connecting China and foreign capitals together with B share. Up to now, China's convertible bond experiences the pilot stage (1992-2001), the re-start stage after approval (2001-2002), and the fast growth stage (2003-now). By analyzing its evolvement, we know that the prosperity of convertible bond in China associates closely with policies and regulations. On April $28^{\text {th }}, 2001$, China Securities Regulatory Commission releases the Issue of Convertible Bonds by Listed Companies Implementing Procedures, and later issues the Notice for Issue of Convertible Bonds by Listed Companies, loosing policy restrictions on the issue of convertible bonds. Afterwards, the issue of convertible bonds grows fast and turns into the most important re-financing tool in domestic capital market.

As a combination of common bond and call option, convertible bond has the characteristics of stock, bond, and option. For investors who hate risks but desire for interests from stocks, convertible bond is an attracting choice. For China's listed companies, convertible bond supplies a re-financing way. Therefore, convertible bond has a wide development space in China. According to statistical data from WIND, till March 31 ${ }^{\text {st }}, 2009$, China issues 61 convertible bonds. 44 of them have already exit from the market. Only 17 convertible bonds still circulate in the market. These convertible bonds collect 114.437 billion RMB. Since early this year, along with the expansion of fluidity and the support of policy, Ashare market rebounds strongly. Driven by the rise of A-shares, convertible bond market rises fast. Holders' arbitrary activities make the stock in convertible market to decrease significantly. The short of convertible bonds causes the rise of convertible bond price. It is predicted that convertible bond will be permitted to issue again in this year.

\section{Main problems in China's convertible bond market}

\subsection{Convertible is issued by public offering, which stops the expansion of market space.}

At present, the issue of convertible bond in China is carried out by public offering. From the corporate board and shareholders conference, to media institutions, to various preparations, to final approval by China Securities Regulatory Commission, the issue of convertible bond needs at least one year. It is time consuming on one hand. On the other hand, it may affect the effectiveness of some convertible bond items designed by enterprises in application. What's more important, the financing only by public offering but no private offering excludes most non-listed companies, especially fast-growth companies, which is not good for the development of convertible bond market. Foreign countries adopt both public and private offering in general. The issuer can make choice based on self conditions, which will benefit the enterprise's commercial operation and economic growth.

\subsection{Conditions for issue are good for traditional industry enterprises but not for new economy growth.}

Foreign experiences prove that an enterprise has two motives for issuing convertible bonds, namely low-rate financing and postponing-equity-premium financing. Therefore, convertible bond is right for small growing enterprises that have increasing demand for financing but the higher risks restrict the scale. So, the active enterprises in European convertible bond market are from fast-developed and newly-appeared industries, such as electric communication, science \& technology, medicine, biological science \& technology, finance, media, and Internet. Rules regulate that the issue of convertible bonds by Chinese enterprises focuses on listed companies that are profitable in recent three years and the average of net assets profit margin should be above $10 \%$. Therefore, Chinese enterprises that issue convertible bonds are mostly from traditional industries, such as steel, machinery, motor, and capital construction. More SMEs, fast-growing scientific and technological enterprises, and non-listed companies have no chance for issuing convertible bonds. This policy only encourages excellent enterprises to issue convertible bonds and sets strict regulations on non-listed companies and low-profit enterprises, which is not good for the long-term development of convertible bond market and the expansion of trade scale. It even hurts the sustainable development of economy and the adjustment of economic structure.

\subsection{Absence of a short mechanism makes institutional investors fail to carry out the arbitrage statistic.}

Convertible bond has the characteristics of bond and stock. Converting the option makes the market to overrate the expected issue price of stock and has the possibility of obtaining premium. Therefore, investors can get relatively stable interests and also return from dynamic trade by arbitrary. And risks are lower. However, there is not a short mechanism 
in China. The unilateral holding decreases the attraction of convertible bond for investors, especially institutional investors.

\subsection{Domestic convertible bond products are designed similarly, lacking of innovation.}

At present, the type of convertible bond is few in China's convertible bond market, only common convertible bond with interests and convertible bond by separate transaction. The design mode is similar. In recent years, the interest rate is close to $0.8 \%$. And the premium from converting into stocks fluctuates heavily along with the stock market. In Europe and other oversea market, the premium can reach $15 \%$ and $30 \%$, mostly between $20 \%$ and $25 \%$. Besides, domestic convertible bond is usually supported by unlimited downward amendment articles. Rules regulate that as the issue price of stock is lower than the conversion price by certain ratio (usually $80 \%$ or so), the enterprise can adjust the conversion price unlimitedly. So, enterprise managers can adjust the conversion price if necessary. It could not protect small and medium shareholders, which conflicts with present laws and regulations.

From relevant experiences in the world, in order to satisfy different investors' needs, the world market, including European market, makes continuous innovations. It covers many types, such as zero-interest convertible bond, common convertible bond (high-interest or high premium, premium re-purchase, and multiple purchases), pre-sell convertible bond before listing, convertible bond with priority, and compulsory convertible bond. Although the convertible bond with interests is still the main body, zero- interest convertible bond rises fast, which accounts for $21.8 \%$ of market share in convertible bond market. In designing the conditions for conversion, there is no special complex amendment article for conversion price. The adjusted conversion price should not be lower than $80 \%$ of initial price of stock. And the adjustment is restricted under certain times. On one hand, it protects the interests of original shareholders. On the other hand, it can help to evaluate the price of convertible bond. Besides, traditional convertible bond takes a single stock as the base. Now more and more takes the stock price as the base. Convertible bond is not only a tool for financing. By using the arbitrary model, it has the function of controlling risks.

\section{Prospect for China's convertible bond market development}

All listed companies in China, no matter they are state-owned or not, are restricted in budgeting. They have a strong desire for financing. In China's capital market, because the convertible bond is regarded as a "financing related with equity", it wins welcome of listed companies. Compared with other financing methods, it has more merits. Firstly, the pressure for excellent performance is small. To issue convertible bond gives a cushioning period for the rise of stock price. It can release the pressure on some key performance indexes, such as earnings per share, and return on net assets. Secondly, cost of financing is lower. The interest rate of convertible bond decreases from early $1.6 \%$ to $0.8 \%$ gradually, which is lower than the interest rate of banks and also that of common convertible bond significantly. Thirdly, the efficiency of financing is higher. The conversion price of convertible bond is permitted to be higher to certain degree than the average of 30 trade days before the public introduction. The price of newly-issued stock is determined by the discount principle. As a result, the financing per stock is higher. These factors make convertible bond more attractive for issuers. But as for how to protect investors' interests, insure information transparency, and build sustainable development convertible bond market, relevant sectors, especially the regulatory and supervision institutions, should participate in this process actively. Here, the key is always the government's support and direction.

\subsection{Perfect the credit grading system and insure information transparency}

Convertible bond belongs to the scope of derivative securities. Its pricing and issuing are very complex. Because issuers and securities dealers always take the financing as the priority in designing conversion conditions, investors must firstly evaluate a project's interests and risks completely, such as risks of rates, re-purchase risk, decline of stock price, and failure in conversion. According to successful world experiences, American, European, and Japanese markets evaluate the credit of enterprises that issue convertible bond. The rate of convertible bond and the premium of conversion are determined by the credit of convertible bond. In Europe, as a relatively conservative investment market, enterprises' credit evaluation is necessary. However, in China, the credit grading on convertible bond is still on the starting stage. The perfection and reliance of credit grading system have not gained a wide recognition of market. In order to insure the safety of convertible bond investment, China mainly adopts the way of offering guaranty for insuring. It is urgent to build and perfect the credit grading system. At present, foreign capitals are rushing into the credit grading market. Among the five credit grading enterprises in China, four of them have been controlled directly or indirectly by foreign 
capitals. In the future, regulations on the sell, the issue, and the approval of convertible bond, and the information disclose will be stricter. Requirements for effective regulatory and supervision on credit grading institutions will be higher in order to defending the issuing enterprise and the credit grading institution hurting investors of convertible bond.

\subsection{Loose the market entrance conditions and encourage growing enterprises to issue convertible bonds}

China has ever regulated strict restraints on enterprises issuing convertible bond. Taking the net assets and other financial indexes as the issue standards is too simple. Policies mainly support large enterprises at the mature stage in traditional industries. It seldom considers the project. The management level should focus on examining the project instead of the issue enterprise. It is better to support the highly-growing enterprises instead of large enterprises, improving domestic enterprises' independent innovation capabilities. Therefore, China adjusts some issue indexes, such as the net assets and the asset-liability ratio, encouraging high-tech enterprises to issue convertible bonds, which is in accordance with China's policy of encouraging innovation and changing economic growth way, offering a wider market space for the development of convertible bond.

\subsection{Encourage innovation of product design and issue way}

Domestic convertible bond market has developed for more than one decade. Conditions for issuing different types of convertible bonds are mature. The state should encourage issue enterprises to produce new convertible bond with different features by changing specific articles based on common convertible bond, and gives it priority of approval. Firstly, prolong the issue term of convertible bond gradually. In China, the shortest term of convertible bond is three years, and the longest is five years, which is far shorter than that of foreign countries, mostly are above ten years. It may force enterprises to take short-term action in choosing financing project, which will harm the enterprises' long-term development. Secondly, permit the co-existence of public offering and private offering. Based on summarizing the successful experiences in world mature markets and domestic market conditions, China can make up regulations on private offering, decreasing the issue cost and perfecting the issue way. Thirdly, institutional investors are growing. Statistical data show that institutional investors hold $90 \%$ of convertible bond circulating in the market. Because investors have strong abilities of defending risks, some institutional investors or enterprises can not only get interests by price difference in trading convertible bonds, but also get an enterprise's controlling right quietly by purchasing amounts of convertible bonds. However, only the enterprise with excellent performance can issue the convertible bond with interests, which can not satisfy different investors' preferences for risks. China should make innovations on relevant regulatory and supervision policies, balancing the interests of different parties in the market, and driving the development of convertible bond market in China.

\section{References}

Cao, Kai. (2008). Why listed company likes convertible bonds. China urban and rural financial news. $26^{\text {th }}$, Feb.

Kong, Fanjun. (2001). Convertible bonds markets in Europe and North America. Securities Market Herald, No.11.

Tang, Jing \& Li, Xiaoxiao. (2007). An empirical study of convertible bonds turning into stocks. Finance \& Economy, No.6.

$\mathrm{Xu}$, Tao \& Xu, Yuanbiao. (2006). China and foreign country's changeable bond market development situation and characteristics analysis. Special Zone Economy, No.1.

Yang, Kangyu. (2002). Development of overseas convertible bonds markets and its lessons to China. Securities Market Herald, No.6. 


\title{
Chôra: Tracing the Presence
}

\author{
Nicoletta Isar (Docteur ès lettres) (Sorbonne) \\ Associate professor \\ Institute of Art History, Department of Arts \& Cultural Studies, Copenhagen University \\ Karen Blixens Vej 1, 2300 Copenhagen S, Denmark \\ Tel: 45-3532-9294Ｅ-mail: isar@hum.ku.dk
}

\begin{abstract}
Challenging the scholarship of the chôra, and what has been thought to be a space of absence and différance that cannot reach presence - an idea advocated by Jacques Derrida - John Sallis takes an important turn in his chorology and explores the possibility of manifestation of chôra. Unlike Derrida, for whom "il y a khôra" (there is chôra), Sallis keeps the definite article (the chora) as an index of certain differentiation in chôra. This article takes as a point of departure Sallis' thesis regarding the manifestation of the chôra, grounded in the manner in which the chora is apprehended, that is, as in a dream. Sallis' interpretation opens up the possibility for a new reading of the dialogue, and offers a tool to examine phenomena occurred in the aftermath of the Platonic cosmogony. One of the most fascinating episodes of the afterlife of the Platonic chora is the Byzantine chôra, presented in the article as a chorographic performative inscription in the visible, where the iconic inscription/graphe is instrumental in revealing the sacrosanct presence of the Incarnation. Finally, in trying to assess the manifestation of the presence of chora, the article takes into account the obscure phenomenon of the "replication of the chôra" in the human body. This I will call the "hepatic inscription" of the presence of chora. A brief assessment will be made around the mantic subjects (the seers), apparently the only human subjects having access to some hidden truth and intimation with the presence of the chorra through divination or inspirational creation.
\end{abstract}

Keywords: Chôra, presence, Plato, Chorology, Byzantine chorography, Divination, Hepatoscopy, Creativity

« nous sommes tous en quête de ce que Platon nomme la chôra, espace lisse et blanc d'avant le signe ; c'est le corps du danseur et c'est la page blanche, vierge cire, où le chorégraphe écrit. » (Serres, M. "Le ballet d'Albe" Genèse, p. 79)

\section{Plato's Chôra}

The fascination with the evasive presence of chorra did not cease to catch the attention of philosophers, psychoanalysts and theologians, Byzantinists, and experts in feminist studies. This paper is yet another quest for the mysterious entity, an attempt for a "chorographic" inscription of her presence from Plato's Timaeus to Byzantine chôra and beyond. Let us start with a brief reading of the Platonic description of chora, and the context in which she first comes forth in the dialogue. One must say from the beginning that Plato's dialogue the Timaeus is about the creation of the universe and the creation of man. This is described as a dramatic process of transition (Tim. 27d-28a) from Being - the intelligible and invisible world (eidos) - to the world of becoming, the image (eikon) of Being - the visible and orderly cosmos. In this cosmogonic process, chôra appears to be instrumental. This third kind of reality (triton génos) - chôra - is the 
nurse, the matrix (ekmageion), the womb and the receptacle in which creation takes place. Chorra precedes creation, and she is fundamentally amorphous, therefore she is invisible. But it is precisely because chôra is "invisible and formless, all embracing" (Tim. 51a-b) that can she receive the properties and determinations that first make the cosmos possible. Chôra is a space-in-the-making, and in-between, because she partakes both of the intelligible, and the phenomenal bodies visiting her in the process of creation, but she retains neither of them. This symptomatology of chora falls under a hybrid and corrupted logic (logismo nothō) - in Derrida's words - "alternating between the logic of exclusion and that of participation" (Derrida, J. (1995). "Khora." p. 89). It is exactly the ambiguous status of chôra, her non-determination, and the bastard logic by which chôra could be grasped ("as in a dream") that made so problematic for the philosophers to define her presence. On this matter, Derrida's view of chôra as a spacing of absence (différance), which cannot reach the presence, stands out as an enduring attitude in the deconstruction of the metaphysics of presence. My intention in this paper is to challenge this view, and, by following the latest scholarship of the chorra exposed by the American philosopher John Sallis, to look into the unstable ground of play between presence and absence in the chorra, without intending however to affix her because, as I hope to demonstrate, movement is exactly her nature. I want to place the discussion on different premises. Inspired by Sallis' chorology, I will first present his view of the traces of manifestation of chôra, and then move into the iconic trace/inscription (graphê) of chôra in Byzantine culture - an interesting example of the afterlife of the Platonic chôra. I will discuss aspects related to image and imagination, dream and the imaginary, bringing finally into the fore the bodily dimension of chôra, or what Sallis calls "the replication of the chôra in the body," which should no doubt have significant implications in assessing chôra's presence.

\section{Chorology: the self-showing moving trace of the chôra}

Challenging the scholarship of the chôra, and what has been believed to be an impossible presence, an idea advocated by Jacques Derrida, John Sallis takes an important turn and explores the possibility of manifestation of chôra. According to Sallis, the manifestation of chôra should be grounded exactly in the manner in which chôra is apprehended, that is, in the dream, described in Tim. 52a-d. This passage from Timaeus Sallis calls the chorology. According to Plato, chôra's reality can be grasped only with great difficulty through a bastard thinking, because she is the stuff of dreams. To look at chôra is as if "we look at it as in a dream" (Tim. 52b). One dreams of the chôra, but in the dream one fails to distinguish the three kinds of being, because this is the symptomatology of the dream. Dreaming is, according to Socrates, mistaking an image for its original (Rep. 476c). But as Sallis points out, the dream not only that confounds the intelligible and the sensible, that it fails to distinguish between the image and the original, but also it conflates the chôra and topos, the chôra and its appearances, which are presented before (Tim. 51b) and after (Tim. $52 \mathrm{~d}-\mathrm{e})$ the chorology. In short, dream confuses, but also discloses that of which one dreams, that is, the chôra. It is at this point of the distinction made by Sallis between the chora itself and its vision in the dream that we truly enter into the heart of the problem of presence of the chôra, because to speak of the chorra itself it would be to speak of some kind of presence. But could we? How could we possibly speak about the presence of the chôra?

According to Sallis, there are passages in the Timaeus, which openly refer to the appearing of the chora, "the almost paradoxical structure of this self-showing." (Note 1) Timaeus refers to the appearing of chora, to her manifestation in the visible using the verb phainesthai, which means "to become manifest," "to show itself" or "to appear to sight" (Tim. 50b-c). The chorra appears however only episodically to sight, only the moments when the bodies collide with her. According to Sallis, she appears only in the traces (ichnos) since only the things that move are visible things and leave their traces in the visible. (Note 2) One could therefore speak of the chora only in movement, as the moving trace of the chôra. But at the same time, it is fair to say that the trace of the chôra is an impermanent trace.

Let us look with Sallis at some important passages in the dialogue revealing this apparition of chôra in the traces, and in the movement of the primordial elements. Before the universe comes to be generated out of the four main elements (fire, water, earth, air), the traces (ichnos) (Note 3) of these elements are set apart from each other in different regions, and the traces of these elements visiting chôra are instrumental in disclosing the ambiguous and enigmatic chôra. The crucial detail is that the phenomenal bodies constantly visiting the hospitable chora are in motion, and that their motion is complex. The movement derives from the difference of the powers (dynamis) manifested within the chora, which shakes her and, in turn, she shakes them, as in the description: "the Nurse of Becoming, being liquefied and ignified are 
receiving also the forms of earth and of air, and submitting to all the other affections which accompany these, exhibits every variety of appearance (pantodapèn mèn ídeîn phainesthai); but owing to being filled with potencies that are neither similar nor balanced, in no part of herself is she equally balanced, but sways unevenly in every part, and is herself shaken by these forms and shakes them in turn as she is moved" (Tim. 52d-52e).

Such picture of the chorra precedes the cosmic order, but this does not necessarily mean that there is disorder in the chôra. Rather, there is a different principle at work. Let us try to identify this principle. To describe how the elements (shapes, characters, forces, traces), still in a primordial state, move and liquefy or ignify chôra, Plato uses the metaphor of "sieve" to describe their motion. This is how he describes the movements inside chorra: "the forms, as they are moved, fly continually in various directions and are dissipated; just as the particles that are shaken and winnowed by the sieves and other instruments used for the cleansing of corn fall in one place if they are solid and heavy, but fly off elsewhere if they are spongy and light." (Tim. 52e-53a) With the sieve one can separate heavy and thick parts of corn from the scarce and light, but as we will see in a moment, the primordial elements take quite a specific turn in their motion: "her motion, like an instrument which causes shaking, was separating farthest from one another the dissimilar, and pushing most closely together the similar; wherefore also these Kinds occupied different places even before that the Universe was organised and generated out of them" (Tim. 53a). Plato's text illustrates how movement inside chôra can't be defined properly as chaotic is reigning. The primordial elements get closer or further following the principle of similarity. They tend to get closer to those more similar, and to get further from the different, forming a particular kind of regions in a continuous movement, showing episodically the chôra. I should perhaps point out that in the Greek culture such agricultural activities, like threshing and winnowing with the separation of the threshing floor of the grain, played an immense role in the Greek anthropology, which could explain the apparent strange metaphor of sieve used by Plato. As Anthony Bryer has convincingly shown, these activities had an authentically dramatic and bucolic break in the agricultural cycle. Threshing floors were instantly recognizable and difficult to erase from the landscape long after they were abandoned. They literally marked the land and human consciousness. In his words: "In the Mediterranean, the circular open-air threshing floor (aloni) is said to be as old as the village harvest ring dance upon it." (Note 4) Such comments are highly significant for my further analysis.

Sallis' reading of the manifestation of the chôra in connection with the chorology is, no doubt, after Derrida's work on interpretation, the most important contribution in the field. For Derrida, chora remains definitively beyond sense and determination. For him, "il y a khôra," there is khôra, but the khôra is not. Unlike Derrida, Sallis introduces the definite article (the chôra) as an index of a certain differentiation, (Note 5) without which the entire discourse on chôra "will collapse into itself, into a kind of discursive autarky." (Pasanen, O. (1997). Double truths: An interview with John Sallis. 113). Sallis's contribution to what has been thought to be the aporetic and impossible presence of chôra, consists in carrying out the differentiaton introduced by the definite article, stressing out "the almost paradoxical structure of this (chôra) self-showing," her manifestation. (Note 6) To conclude this brief reading of the dialogue about chôra's manifestation, one may say that there is movement in the chôra, following the Greek view of spatiality, and that the presence of the chôra could be only glimpsed in this movement, therefore we could call it a "motional presence."

At this point of the analysis it might be also useful to make a brief philological note around the term chôra, although I fully share Sallis's view on chôra's untranslatability. The ancient terms chôra and chôros) are commonly translated as delimited (Note 7) space, region, land, to distinguish it from the place (which is tópos in Greek). But there is a sense of movement contained in the Greek word chôra, which is linked to the verb chôréô having two senses: first, it means to withdraw (give way), to make room for another, like in the Homeric Hymns: "The earth gave way from beneath(gaîa d" enerthe chórêsen)." (Note 8) The sense is of withdrawing, while inscribing the space in its withdrawal. Chôréô means also to go forward, to be in motion or in flux, like Heraclitus said when he referred that nothing in the world remains still, but rather everything moves (pánta chôrể). According to the context, the word chôréô indicates either a movement with the sense to go forward, or to retreat, withdraw or recede, in both cases having the effect to "make room for," generating a particular kind of space. I should like to introduce also another term, which might help me further in the analysis. The ancient Greek word chorós conveys the idea of collective coordinated movement (as action, the dance), or of collectivity in movement (as agent acting, the choir), like chorós ástrôn (the dance of the stars), or chorós melitôn 
(the dance of the bees). This movement is specifically circular; it is an orderly circular movement. It is highly important that chorós designated in ancient culture the dancing ground, a term metonymically derived from the place where the choir (chorós) danced. The verbchoreúô meant to dance in a choir, or in a circular manner. The wordchorós could be translated in Modern English, according to the context, either as "to dance around" or as "the choir of dance" or simply as "the choir." The semantic of these words was almost fully preserved in the Greek-speaking world to come after the fall of the Antiquity, that is, in Byzantium.

\section{Byzantine iconic inscription of the chôra}

In the history of the Platonic chora, there is an interesting case of appropriation of the term, which has not been enough discussed from the perspective of the Platonic dialogue itself. This is the Byzantine chôra-a most fascinating synthesis of Christian theology and anthropology, on the one hand, and Platonic metaphysics and mysticism, on the other. For the Byzantines, the space designated by the terṃchôra was the matrix of the Incarnated Word, the most sacrosanct presence in Christianity celebrated in the holy icon, and the sacred space of liturgical participation. Thus, speaking of the Incarnation, Gregory Nazianzus defines it as the space chôrêtòn kai achôrêton, (Note 9) that is, "that which occupies space, and does not occupy space.” The discourse of the Byzantine chôra is apophatic (negative discourse), (Note 10) and oxymoronic, (Note 11) apt to address phenomena located between visible and invisible, both visible and invisible; furthermore both presence and absence. The paradoxical phenomenality of the iconic chora is founded on a theology of kenosis, (Note 12) which sole could explain how emptiness and fullness, presence and absense are "foiled" and transfigured in the choraic space. In a most conspicuous way, the language of the Cappadocian Father resembles Plato's, and in a reversed way the deconstructivist discourse. (Note 13) One must stress that in the Byzantine context the earlier record of the termchôra emerged in the context of the most violent debate around the definition of the icon in $9^{\text {th }}$ century, and its capacity of the icon to contain the presence of God, which in some ways resembles our concerns for a quest of the presence in/of chorra. The argumentation of the Iconodules (those in favour of the image of God in the visible) was conducted towards the idea that the icon does not represent the depiction of the essence (ousia) of presence of God, neither is it a mere artistic representation, but nevertheless is an image in which God Incarnated inscribes His presence. This thorny problematic around the image of God received a thorough theoretical definition of the icon in the text Antirrheticus by Nicephoros the Patriarch of Constantinople. To the doctrine of sign (sêmeion) of the iconoclasts, for whom the inscription (graphê) circumscribes and limits the divine infinity, Nicephoros opposes one of the most richly conceptual theories of pictorial inscription, as trace/inscription and word, contained in the uncontainable choraic space. In Antirrheticus II, two concepts are defined and clarified: inscription (graphê) and circumscription (perigraphê). Nichephoros defines circumscription in connection with the Aristotelian topos, as a limitation of the body that it contains. Christ, taking on a body, is circumscribed in space (topos), but by virtue of His divine nature, He is outlined in an uncircumscribed space, abstract and infinite, in chôra. The icon generated by the iconic inscription (graphê) has its specific space, which reveals thechôra and not the tópos, for which the Christian theorist of the holy image applies to the verb ekchôréo (Note 14), that is, to chôra notion. (Fig. 1) The iconic inscription (graphê) is a trace that defines a space that is and is not there (achôrêton). As Marie-José Mondzain comments, the iconịcchôra is a space extension, where chôréo means both to occupy a space and to contain something, which means that the content and the container coincide. The point of contact between them or the edge of this space is zône, in Mondzain's interpretation, which in Greek means the peripheral belt of contact between the womb of the mother and the body of the child (Mondzain-Baudinet, M.-J. (1996). Image, icône, économie p. 199). The iconic line (graphê) is the coinciding trace between content and container, which makes manifest into visible the limitless Word(aperigraptos Lógos). (Note 15) (Fig. 2) The iconic inscription (graphê) could be this trace in the visible of thechôra space of the Logos, which reveals itself completely only as an imaginary (hennoêsei) place (Note 16), yet to be fully enacted in the liturgical performance.

One of the most fascinating episodes in the history of iconic inscription of the presence in Byzantium is related to the notion of "empsychos graphe" (ensouled painting), first coined by the Byzantine humanist Michael Psellos (1017-1078). The notion was brought forth by Hans Belting in his book Likeness and Presence: A History of the Image before the Era of Art, to which he devoted an entire chapter on "living painting." Psellos describes the icon not merely as a reproduction of the model, but as "full of life and nowhere lacks movement" (Belting, H. Living Painting, p. 261). 
Bissera Pentcheva and Charles Barber added important researches to the clarification of this notion. As Barber so convincingly demonstrated, Psellos's term of "empsychos graphe" seems to point out to an "authentic presence" that is mediated by the painting, but which is not the product of the work of art. In his accounts of looking at icons, Psellos describes it as a phenomenon "in between" real and imaginary. There are, according to him, two sources of the image: the art (téchne) as the human process of making a likeness and an ineffable admixture of grace (cháris), which "does not liken anything else" and which is responsible for the emergence of presence, eventually perceived in the ensouled painting. The extreme manifestation of presence is described by Psellos in the Miracle of the Curtain at Blachernae, the extraordinary thing that happens to the icon on the sixth day of the week after the sunset. People present at that hour in the church witness the miracle (paradoxon) by which the curtain (peplos) before the icon suddenly is buoyed up as if a breath of wind (pneuma) moves it. This phenomenon is described by Psellos as a holy "visitation," which eventually leaves traces in the visible, it alters visibly the image: While the event is happening, the appearance of the heavenly image changes, and it receives, I believe, her (the Virgin's) living visit (empsychos epidemia), making what otherwise remained invisible, visible." Psellos' account of the "empsychos graphe" of the image is immensely relevant for the assessment of the presence by iconic inscription. The charismatic aspect of the iconic graphe described by Psellos as the agency by which the invisible comes into the visible is crucial. One aspect of this phenomenon needs however to be introduced in the equation, namely, the performative dimension of presence manifested in the liturgical enactment. This aspect makes the substance of my research project devoted to chorography, which is exactly focused on the presentification of the chôra in performance. I called it Byzantine Chorography.

\section{Byzantine C $h$ or o g r a p hy-a space for choreographic inscription}

In my research project "Byzantine chorography (Note 17) I challenge the exclusive reading of chora as a spatial oxymoron of the Incarnation discussed in the Byzantine circle of scholarship, and I attempt a definition of the space "in-between" as a space of enactment of presence, a sacred performative space. My Byzantine chorography, a made up term or a syntagm, may be translated as 'writing (graphê) space (sacred)' or 'inscribing the sacred space with the dance.' Chorography studies the making of sacred space in Byzantium not as a static notion of some kind, but as a performative spatial inscription. The discourse of chorography is the discourse of the trace of the invisible sacred in the visible. The definition of the trace (inscription) of thechora is obviously at the heart of choro-graphy, due to the instrumentality of graphê (the iconic inscription) in revealing the sacred (hierós). It draws on the intimate relation between chôra and chorós, between space and movement, deeply rooted in the ancient Greek language and imagination.

One should stress the idea that Byzantine church performances frequently refer to actions in which angels and humans are engaged. The Heavenly Liturgy is the prototype of the Earthly Liturgy, in which humans could and should join the angelic performance, in which the liturgical hymns are "revealed in a holy manner." (Note 18) and humans can partake into the great cosmic praise in which the whole of creation takes part: "Those in heaven and those on earth form a single festal assembly; there is shared thanksgiving ... one single choir" (Chrys. PG 56, col. 97). This idea is exemplary explained in the Eucharistic mystery as a hierarchical choreia described by Pseudo-Dionysus in his Ecclesiastical Hierarchy. The angels circled together in an invisible series of choruses known as the Celestial Hierarchy. The first rank of heavenly being performs a choral movement: "It circles in immediate proximity to God. Simply and ceaselessly it dances around (perichoreúousa) an eternal knowledge of him. It is forever and totally thus, as befits angels." (Note 19) In the world below, the bishops, priests, deacons, and laity imitate the heavenlychoreía, according to their degrees of illumination. The Ecclesiastical Hierarchy is an imitative movement gradually leading to ecstatic communion with God, by which the presence is liturgically enacted. The function of the vast chain of heavenly and earthly orders described by Pseudo-Dionysus was to unite the highest ranks of the angels with the last member of the congregation through participation and shared knowledge of the divine presence.

In a series of articles devoted to Byzantine chorography, I present some cases of what I call "choreographic inscriptions" in the Byzantine chôra, manifested as a space of participation - a living body of liturgical experience. (Note 20) In the liturgical experience, the movement performed (chorós), the faithful him/herself, and the sacred space (chôros) thus created were intimately connected. Space and beholder fused together in a single vision in which everything moved round like a chorós indeed. This dynamics of vision reveals not only how space and movement were 
conceived together in Byzantium, but also how space was experienced. Space and beholder were neither detached from each other: they formed a choir. It is such experience of space that might explain the linguistic coalescence of the terms chôra, chôros and chorós. At the same time, this points out to a general principle of participation in the Byzantine sacred space. Presence is participative there is no presence per se, but an experienced presence. Thus, in a space of liturgical experience, the movement performed (chorós), the faithful him/herself, and the sacred space (chôros) thus created were intimately bound together and impossible to be conceived as detached, independent, and abstract entities or concepts. The final outcome of such experience was a living space of presence and participation into the divine, a personified space, identical and continuous with the self (persona) and with the divine - an event, one may say, of ontological continuity between Being and becoming. (Fig. 3)

Sacred space of the Byzantine chôra was a space of presence and presencing, a verb rather than a noun; hence the type of realization of sacred space was the dance, chorós. This was not a mere physical extension of space, but a living body of liturgical experience. It was a space of 'sacred containment', from which the modern distinction between contained space and container should be removed in order to make room to that power of creative imagination, which has once enabled the participation of being in the wholeness of the universe and in Being. Gesture, motion, choreography - this is the evanescent yet essential language in which the idea of the sacred is expressed in space. Here, in the dance, one can perhaps see united those two elements of sacred space, the material frame and the numinous presence, which is called into being within it. For in the dance, as Yeats wrote, the two are united: 'How can we tell the dancer from the dance?'

\section{Chôra in the body - a living presence}

The Byzantine case of the chorra put forth explicitly the role played by the human agent in the enactment of the presence. Presence emerged in the perfomative participation. It might be therefore instructive to go back to Plato's dialogue, fundamental for the assessment of the presence. It must be stressed once more that Plato's dialogue Timaeus is about the creation of the universe and the creation of man, both shaped according to the principle of likeness with the Demiurge, with consequences that I will try to asses here. As it comes out later, in the dialogue, Timaeus inquires not only into the making of the cosmos, that is, order, but also into the condition of what is not order, neither for the human body nor for the universe before it becomes the orderly universe. What is disorder in cosmogonic terms is felt as disorders (stáseis) and diseases (nósous) in the human body, which is shaped according to the immortal principle of soul. The aspects concerning human pathology and creativity and the relation to the chora are largely discussed in my article "Creation and Pathology: An Inquiry into the Origins of Illness and Human Response." I will therefore refer here only to those aspects pointing out specifically to the emergence of presence in the bodily chôra, and eventually draw some parallels to the cosmogonic chôra.

It is interesting to note that Plato's advice to man in order to overcome disease (nósous) is to reverse that state of imbalance by constantly imitating "the nurse of the universe," that is, the cosmogonic chôra. This idea does not derive from the mere relation between macrocosmos and microcosmos, which is nevertheless the principle at work in Plato's myth, but it has more specific reasons. The main reason is because the cosmogonic chora is replicated in the human body. Thus, according to him, in so far as the disease is the reverse of order and sameness, it is necessary to constantly work on the restoration of the symmetry and balance between soul and body, which must reflect back the prototype. But this is an ongoing and permanent process, by which man should constantly adjust his image to the archetype by imitating the chôra. Man should imitate "the nurse of the universe" (Tim. 88d), just as in the earlier role of the image of the nurse in the making of the cosmos (Tim. 49a, 52d), so that he may stay tune to his creator. As Plato describes, the imitation of the nurse chôra consist basically of such action, which "never, if possible, allows the body to be at rest but keeps it moving, and by continually producing internal vibrations" (Tim. 88e), thus "duplicating the state of the chora filled with traces being winnowed out" (Sallis, Chorology, 136). As I have already mentioned, the Platonic advice is a logical advice because the chora itself is replicated in the human body, but its specific location in the architectural edifice of the body will be capital to the understanding of the manifestation of the choraic bodily presence.

As Sallis has pointed out, in Timaeus' discourse on the human body there are numerous indications as to how the chôra is replicated within the body itself, and how such replication is unmistakably indicated in the case of the liver (Sallis, 
Chorology, 122, 135). It is well known the crucial role played by the liver in the human body. But most instructive is to note the terms in which Plato speaks about the liver as a ground of some specular reflection, as a mirror. One must stress that the chief quality of this organ is to reflect like a mirror. The liver is smooth, shining (lampros), sweet, and bitter. Likewise, the nurse itself of creation was described as a mere mirror in which perpetual being would be reflected and the cosmos fabricated in the same way that all things could be made by the clever and wonderful man who took a mirror and carried it around everywhere (Rep. 596c-d). Both the cosmogonic and the bodily chora seem to have been conceived after the same paradigm of a specular ground able to host the reflection of the image. The idea of the hepatic chôra in the body like a mirror device, described by Plato (Tim. 71b), is immensely important as it will bring us close to the presentification of the chôra.

The function of the liver in the body will bring us even closer to the image of bodily chôra. As Plato explains: "To guard against this (i.e. images and phantasms) God devised and constructed the form of the liver and placed it in that part's abode; and He fashioned it dense and smooth (lampros) and bright and sweet, yet containing bitterness, that the power of thoughts that proceed from nous move in the liver as in a mirror that receives impressions and provide visible images, should frighten this part of the soul" (Tim. 71b). The function of the liver is to receive images from the diánoia (Tim. 71c) by a "breath" (epipnoia); "the movement produced (by a stroke that is sound), beginning from the head, and ending in the region of the liver, is hearing" (Tim. 67b). That's why the liver was apparently fashioned in the body (Tim. 71f.), to be an instrument or intermediary of the highest part of the soul whereby the latter could show visions to and terrify or appease tò epithumetikón (the motion of desire). The liver is the ground and the means whereby tò epithumetikón (desiring) receives intimations from the higher part of the soul or from the outer world. When the mental power bears stern threats it uses the liver's bitterness exhibiting bilious colours, and by contraction making the surface of the liver wrinkled and rough. On the mirroring surface of the liver, the traces of passions and disorders (stáseis) are the hepatic presence of the chora, the bodily traces of its presence. It is why a subsidiary organ is provided, the ekmageion, which is described as a napkin or a wiping cloth laid besides a mirror, whose primary function is precisely to keep the liver bright and clean (Tim. $72 \mathrm{c}$ ). With respect to the body, we may call the physiological process of cleansing and imitation of the chôra by the term choral technique. (Note 21) It imitates the nurse in the primordial cosmogonic process of moulding, which is said to "begin by making it even and as smooth as possible before they execute the work" (Tim. 50e). The making of the cosmos is an ongoing process of confronting the motional presence in the chora; likewise, the making of man is also an ongoing process of adjustment to the model, seized by the hepatic inscription of presence in the bodily chôra. And thus, we may conclude, the phenomenal bodies colliding with the cosmic chôra in cosmogony are, on a macrocosmic plan, what the wrinkles on the liver in the human body are for anthropogony: they are both traces of the ineffable presence of the chorra.

\section{Dreams, divination, inspiration - channels of presentification of the chôra}

Yet one must recognize that the access to presence, to this kind of image-mirror-reflection of the chora, is most problematic. As Plato emphasized already in the making of the cosmos, chôra's reality could only be grasped with great difficulty through a bastard thinking. To look at the chôra is as if "we look at it as in a dream" (Tim. 52b). But in the dream one fails to distinguish the three kinds of being, according to Socrates, mistaking an image for its original (Rep. 476c). As I have already mentioned, the function of the liver is that to receive images from the diánoia (Tim. 71c) by a "breath" (epípnoia), which results in some traces inscribed on the smooth surface of the liver. This vision and image on the liver is man's share of truth, according to Plato, because according to the philosopher, man could in some degree lay hold on truth, but on some condition. To have access to some truth, he says, "God gave unto man's foolishness the gift of divination." The shining (lampros) surface of the liver is able to reflect thoughts because the soul in the liver area is capable of divination. But vision of divination is achieved not with reason, but as in a dream: "no man achieves true and inspired divination when in his rational mind, but only when the power of his intelligence is fettered in sleep or when it is distraught by disease or by reason of some divine inspiration" (Tim. 71e). The person having access to such vision, due to his personal affection is called mántis, a diviner. A distinction must be however made between "the diviners" (mánteis) having the experience of inspired divinations (enthéois manteiais), and the 'prophetes', the interpreters (hypokritai) of these visions (Tim. 71e-72b). 
The diviners belong to the great family of the holy seers, thought in the ancient Greek world to have been endowed with mantic inspiration, a state of divine madness or possession. Pythias was one of these seers (mánteis), that is, "raving" (manikoi) in "madness" (mania) able to communicate with the divine. In their state of inspiration, these human agents were "beside themselves" (ekstatikoi), but "full of God" (entheoi), that is, "enthusiastic." But it is only in this state of being that were they able to say things impossible to articulate in a normal state, to have some access to truth, as Plato stressed out (Tim. 71e). They had the gift of seeing, of knowing, of divination. (Note 22) They had access to the ultimate presence, and the mediation-bridge to presence was their own body. In his poignant description, Plato resembles them to a fountain out of which the inspirational water comes out. The passage comes from the posthumous work, the Laws: "There is ... an ancient saying - constantly repeated by ourselves and endorsed by every one else - that whenever the poet is seated on the Muse's tripod, he is not in his senses, but resembles a fountain, which gives free discourse to the upward rush of water" (Laws 719c). Therefore, says Plato, the poet is the recipient of higher inspiration, the passive unconscious mouth. A specific human typology, subject to disturbances and vibrations (seismous) taking place in the chôra partakes in a similar experience: these are the poet, the diviner and the melancholy artist. Yet their response appeared to be a discourse beyond logic, and cognition: the prophetic discourse, and the poetic discourse (furor poeticus) characteristic of the poet and the melancholy artist. One must insist that the access to presence is most exclusive and reserved to such subjects and channels of some exceptional inspiration.

Thus, dream, divination and inspiration appear to be spaces of the imaginary and human imagination where the presence of the chora emerges through the instrumentality of the body. I should perhaps give one concrete example of art work in which the idea of space in-between of the presence in divination is finely suggested. This is illustrated in one of the many preserved Etruscan bronze mirrors found in the Etruscan culture, which certainly should be connected to the practice of divination by the liver, following the Babylonian Hepatoscopy. Hepatoscopy is the ancient tradition of examination of the visceral surface of the liver, though not the human organ, but of a sacrificial sheep (amutu). (Fig. 4) This is a bronze mirror from Vatican City, Museo Gregoriano Etrusco, showing Calchas, the priest of Apollo, mentioned in Homer's Iliad - an elderly haruspex examining the liver of a sacrificed sheep. (Fig. 5) The Etruscan inscription reads his name Xalxas, and the caption: "A winged soothsayer incised on a bronze mirror reads omens from an animal's liver". The mythical Greek soothsayer Chalchas is represented with the attribute of wings, stressing his function of go-between earthly and transcendental reality. His posture, one foot on the rock upwards, and the other one touching the earth, suggests his interstitial placement in-between realms, in the chora, where divination takes place performed by the haruspex, who establishes contact between the two worlds. The circular shape of the object, its polished mirror surface, as well as, the explicit iconography related to divination engraved on the surface opposite to the reflecting part, makes it a most interesting case of choral technique.

\section{Conclusion}

\section{Creativity and the presentification of the chorra}

I would like to take up from the provisory conclusion formulated above concerning the idea that the access to presence appears to be a most exclusive matter reserved to some exceptional subjects. I have called these human subjects sujets en process (subjects in process/in trial), using J. Kristeva's concept. The sujet en procès, subject on trial, is, according to Kristeva, the psychoanalytic subject interminably in process/on trial between the semiotic and symbolic. Such is the poet, the diviner and the melancholy artist; these subjects are "semiotized" bodies, which live in a permanent "state of scission." It is why they are open to the source; they are channels of some exceptional inspiration which have access to the presence of chora in the body. To follow the same pattern of thinking of Kristeva, one should briefly conclude that the poet and the inspired diviner are facing the negativity process of the chôra in which drives are manifested, facing simultaneously the semiotic (unconscious) as well as the symbolic. They are exemplary subjects to describe what Plato suggest to be the necessary gesture to restore symmetry and balance between soul and body in the imitation of the nurse chôra, a never ending process. To remind Plato's view, this act consists of never allowing the body to rest but keeping it moving, and by continually producing internal vibrations (Tim. 88e). The poet dwells with this rupture, at this boundary and is comparable, according to Kristeva, to a scapegoat. Therefore, in Dennis King Kennan's view, the genesis of the subject is "a scene of sacrifice" (Question of Sacrifice, p. 33). This "event" of sacrifice, the poetic revolution (which 
Kristeva clearly distinguishes from art as a mere cultural form of human activity) is the interval/ the passage from semiotic violence to symbolic order. Kristeva's view of the matter, concerning art as the only means by which jouissance (pleasure), can infiltrate the symbolic order (Note 23) is instructive. If creation is, like its human subject, on trial, basically consisting in constantly confronting the choraic motility of the semiotic chora, then creation is that flow of jouissance, which is therapeutic. In this dramatic process, creation (vision) emerges as a process of trasformation of the semiotic into the symbolic, which is always a process of becoming. Fighting against the unbalance in the body, the mantic subjects confront permanently the chôra, turning into an asset what is a lacuna in the body, coverting illness into creativity.

The space of creation and mantic inspiration has some kinship perhaps to the Platonic metaxý (the interval), where the daimôn (Note 24) dwells, or a revelation of some kind always occurs. It is where the middle voice is prophered - to borrow Gamard's term. This space of dream and imagination is a phantasm mirror image - therefore it must be assiduously polished according to the choral technique (Manolescu, A. The Pilgrim's place, p. 56). The story reported by the Persian poet Rumi, familiar with the Byzantine mode of thinking and their vision, is most informative in terms of this technique. The poet tells the story of a contest set up at the court of the Sultan between the painters from China and Byzantium to decorate two walls of his palace facing each other, a curtain separating them. While the Chinese employed all kind of paintings to display their virtuosity, the Greeks were content to spend their time polishing their wall. When the curtain was lifted up, one could admire the magnificent frescoes made by the Chinese reflected on the opposite wall of the Byzantines sparkling like a mirror. What the Sultan has seen on the Chinese wall looked much more beautiful reflected on the Byzantine wall. As Rumi explains, the Greeks are not learned peoples but they polished their heart and purified it of desire, and this purity of the mirror is no doubt the heart, which receives numberless images. Likewise, the saint keeps in his bosom the infinite form without form of the Invisible reflected in the mirror of his own heart (De Vitray-Meyerovitch, E. (1978). Anthologie du soufisme, pp. 38-39, apud Manolescu, A. The Pilgrim's place, p. 56).

Finally: few words on the act of creation as a moment of revelation, a disclosure of presence. I take here Sallis' path (Sallis, Daydream, esp. 404-406) in discussing the point where the good and the chora are brought into proximity, the moment of vision of the thing "in its own chora," found at the beginning of Book 7 of the Republic. Socrates connects the sites and stages undertaken by the prisoner with respect to the affections in the soul and the levels of disclosure of beings, until finally, as a culmination of his ascent, he would be able to look upon the sun, not upon its appearances, but "the sun itself by itself in its own chôra" (Rep. 516b). By now we know that such glimpse of presence could only be acquired as a godly gift that the god gave to man's foolishness in divination (Tim. 71d). As Alberto Gomez, a theorist of the chôra, has pointed out, Plato understood that the absolute truth and goodness, like the sun itself, could never be contemplated directly and made an object of pure knowledge, but rather had to be experienced as the lighting that makes it possible for the things of our world to be what they are, indeed, as a reflection in the mirror, in the chora (Pérez-Gómez, A. (1994). Chora: The Space of Architectural Representation. p. 6). The work of art that allowed such lighting to be experienced could be perceived as a means of presentification of the chôra. In Gomez's view, Plato is describing nothing less than the space of human creation and participation, postulating a coincidence between topos (the Greek word for natural place), and chôra, where chora was a distinct reality to be apprehended in the crossing of being and becoming, in the dream. The manifestation of the chora was, in his view, a prerogative of human artifacts and imagination, which in Plato's tradition it was the province of inspired poetry and music.

The creation of the amphitheatre, contemporary to Plato's philosophy, is an exemplary choraic space of human creation and imagination, a reflection of a paradigm laid up in the heaven. The plan of the theatre was apparently itself construed in accordance with the image of the sky. Tragedy inhabited this space as a space of transition, where the event in-between was enacted, and the mystery was epiphanically manifested at the very moment of performance. The drama was built upon the idea of participation in the epiphany through contemplation (theoria) and imagination, where mimesis was not mere imitation, but the expression of the manifestation of experience through movement in the chôra, on the dance platform or the orchestra (choros), where the chorus performed the circular dance. The event took place in the chorus, that is, in the performance on the chorra space, which was danced out by the choir. This was a space of 
vision and contemplation, of participation and recognition, indeed a kathartic space, of restoration of the cosmic order, as well as of the human microcosm. Embedded within the confines of the cosmos as well as of the human body, chorra appeared to be always there, where creation took place, and was constantly in the process of making. The association between the theatre of Epidaurus and the Temple of the god healer Asclepius is perhaps exemplary for the idea that in the Greek culture disorder was understood to be a psychosomatic phenomenon. Therefore it was natural that medicine, ritual and art worked together, according to the principle, by now a Classical adagio, formulated by Plato: "God ... bestowed upon us vision to the end that we might behold the revolutions of Reason in the Heaven and use them for the revolvings of the reasoning that is within us" (Tim. 47b).

\section{References}

Barber, C. (2006). Living Painting, or the Limits of Pointing? Glancing at Icons with Michael Psellos. Reading Michael Psellos (Leiden), 117-30.

Belting, H. (1994). Living Painting": Poetry and Rhetoric in a New Style of Icons in the Eleventh and Twelfth Centuries, Likeness and Presence. A History of the Image before the Era of Art. The University of Chicago Press, pp. 261-296.

De Puma, R. D. \& Guthrie W. K. C. (2001). An Etruscan Mirror with the Prophesying Head of Orpheus, Record of the Art Museum, Princeton University, Vol. 60, 18-29.

De Vitray-Meyerovitch, E. (1978). Anthologie du soufisme, Paris, pp. 38-39, apud Manolescu, A. The Pilgrim's place, p. 56.

Derrida, J. (1995). "Khora." In On the Name, ed. Thomas Dutoit, tr. David Wood, John P. Leavey, and Ian Mcleod, Stanford: Stanford University Press.

Gamard, E. B. (Feb. 1995). Virgil/Beatrice: Remarks on Discursive Thought and rational Order in Architecture. Journal of Architectural Education (1984-), Vol. 48, No. 3, 154-167.

Isar, N. (2000). The Iconic Chôra.The Kenotic Space of Presence and Void. Transfiguration 2, 65-80.

Isar, N. (May 2009). Europe's Journal of Psychology (EJOP) (Forthcoming article).

Isar, N. The vision and its "exceedingly blessed beholder". Of desire and participation in the icon. Res: Journal of Anthropology and Aesthetics, 38 (2000), 56-72.

Kristeva, J. (1977). "Le sujet en procès", Polylogue, Paris: Seuil. See my forthcoming article "Chôra : Creation and Pathology. An Inquiry into the Origins of Illness and Human Response.” EJOP July 2009.

Mondzain-Baudinet, M.-J. (1996). Image, icône, économie Les sources byzantines de l'imaginaire contemporain. Paris.

Mondzain-Baudinet, M.-J. (Fall 2000). "Iconic Space and the Rule of Lands," Hypatia vol. 15, no. 4, 66.

Nicephori Archiepiscopi Constantinopolitani, Refutatio et eversio deliramentorum Adversus Salutarem Dei Verbi Incarnationem, Antirhreticus II (PG 100); French translation: Nicephore Discours contre les iconoclasts, traduction, presentation et notes par Mondzain-Baudinet, M.-J., Paris, 1989.

Onians, R. B. (1954). The Origins of European Thought. About the Body, the Mind, the Soul, the World Time, and Fate. Cambridge University Press, p. 87-88, note 9.

Pasanen, O. (1997). Double truths: An interview with John Sallis. Man and World, 30.

Pentcheva, B. (Dec. 2006). The performative icon. The Art Bulletin, 631-655.

Pérez-Gómez, A. (1994). Chora: The Space of Architectural Representation. Chora. Intervals in the Philosophy of Architecture, vol. I, McGill-Queen University Press.

Plato IX (The Loeb Classical Library Nr. 234), Translator R. G. Bury. Harvard University Press.

Psellos, M. The Miracle of the Curtain at Blachernae. In Belting. Likeness and Presence, pp. 511-512.

Sallis, J. (1999). Chorology: On Beginning in Plato’s Timaeus. Indiana University Press. 
Sallis, J. (2002). On Translation. Indiana University Press.

Sallis, J. (3/1998). Daydream, Revue Internationale de Philosophie, Vol. 52, No. 205, 397-410.

Serres, M. (1982). "Le ballet d'Albe" Genèse, Bernard Grasset, Paris, p. 79.

Yeats, W. B. Among School Children.

\section{Notes}

Note 1. Pasanen, O. (1997). Double truths: An interview with John Sallis. Man and World, 30, p. 113.

Note 2. The phenomenal appearances, copies of the eternal Forms, are visible and they are subject to becoming (mímema dè paradeígmatos...génesin echon kaì oratón) (Timaeus, 50c).

Note 3. The Greek íchnos appears in Timaeus 53B, and can be translated as trace, but also as imprint, or footprint, is a very important notion to come close to chôra. The trace has some indexical relevance, you may think, but it is only relative and temporary, due to the impermanence of the trace. Unlike ichnography, the science of fossils, invented by Leibniz, the footstep of the chôra is volatile: "(chôra) fleets (phéretai) ever as a phantom (phántasma) of something else" (Tim. 52C).

Note 4. Bryer, A. (2002). "The Means of Agricultural Production: Muscles and Tools." In The Economic History of Byzantium: From the Seventh through the Fifteenth Century Angeliki E. Laiou, Editor-in-Chief Dumbarton Oaks Papers 39, 109. I owe entirely this reference to Jonas Johnsen Helgason Christensen, to whom I would like to thank very warmly.

Note 5. My emphasis.

Note 6. Ibidem. My emphasis in the quotation.

Note 7. The verb chorizo, which is a later term, means "to separate," with the sense "to make (-ízo) a delimitation between two things"; from here we have chôrismós which means "parting."

Note 8. "To Demeter," 429f.

Note 9. Nazianzus, G. Epist. 101 (PG 37, col. 177B); also The Akatistos Hymnos, icos 8.

Note 10. The discourse on the transcendent, which contains both saying and unsaying.

Note 11. A combination of contradictory terms ("living corpse" or "black light").

Note 12. The kenosis (from the Greek kénôsis = emptying; the verbe kenóô = to empty) attempts to solve the paradox between the nature of God and man as united in Christ. It refers both to the Incarnation and His Sacrifice. For example in Philippians 2: 7: "Jesus made himself nothing (ekénôse)."

Note 13. I am thinking of some paradigms at work that could be recognized in metaphysics, theology and deconstruction, but this article will not undertake the difficult task of developing on this subject.

Note 14. "H graphê dè ekkechôrêke pollô." (Nicephori Archiepiscopi Constantinopolitani, Refutatio et eversio deliramentorum Adversus Salutarem Dei Verbi Incarnationem, Antirhreticus II (PG 100, col. 360 A); French translation: "Mais l'inscription est très loin de là (i.e., tópos)," in Nicephore Discours contre les iconoclasts, traduction, presentation et notes par Mondzain-Baudinet, M.-J., Paris, 1989, p. 170.

Note 15. Romanos Melodos, the hymn "Rejoice O bride unmarried."

Note 16. “L'espace dont il s'agit est imaginaire... » Nicephore Discours, « Preface, » p. 28.

Note 17. The project is attached to the international network of study of sacred space - Hierotopy - founded by the Russian scholar Alexei Lidov..

Note 18. "And thus the Holy Scriptures have transmitted to the inhabitants of earth certain hymns of this hierarchy in which is revealed in a holy manner the supreme illumination allotted to them. Some men, translating this illumination into sensory images, cry out in a "voice of a great rushing, saying, "Blessed be the glory of the Lord from his place"" 
(Ezekiel 3: 12); other men lift up their voices in that most celebrated and revered utterance from the Scriptures: 'Holy, holy, holy is the Lord of hosts: the whole earth is full of his glory' (Isaiah 6: 3) (The Celestial Hierarchy VII. 4).

Note 19. Pseudo-Dionysius. The Celestial Hierarchy VII. 4, p. 165. The same is found in Is. 6:2 and Rv. 4:4.

Note 20. In my article "The Dance of Adam: Reconstructing the Byzantine Chorós," I read the Resurrection as a cosmic event in which the space of creation is restored again. Creation is restored above and below, in the heavens and on earth, by the circular movement that initially turned chaos into order, the sacred circular movement liturgically performed around the church at the Resurrection, which is a sacred space inscribed out by the holy fire. This is a chôra-chorós (space-movement) type of space, as the likes of fire are held in the chôra. (Isar, N. (2003). 'The Dance of Adam: Reconstructing the Byzantine Chorós,' Byzantinoslavica 61, 179-204) See also, Isar, N. (2005) "Chorography (Chôra, Chôros, Chorós) - A performative paradigm of creation of sacred space in Byzantium." In Hierotopy: Studies in the Making of Sacred Space, pp. 59-90; and Isar, N. (2005). "Chóros: Dancing into the Sacred Space of Chora," Byzantium tome LXXV, 199-224.

Note 21. I borrow this term from Manolescu, A. (2001) The Pilgrim's place. The symbolic of space in Eastern Christianity (in Romanian), Paideia Bucuresti, p. 56.

Note 22. For more on the subject, see Tigerstedt, E. N. (Apr.-Jun. 1970). "Furor Poeticus: Poetic Inspiration in Greek Literature before Democritus and Plato," Journal of the History of Ideas, Vol. 31, No. 2, 163-178.

Note 23. "Art - this semiotization of the symbolic - thus represents the flow of jouissance into language." (Kristeva, J. (1984). Revolution in Poetic Language, tr. Margaret Waller, Columbia University Press, p. 79)

Note 24. Between god and mortal ("A great daimon, for the whole of the daimonic is between [metaxý] god and mortal"). 


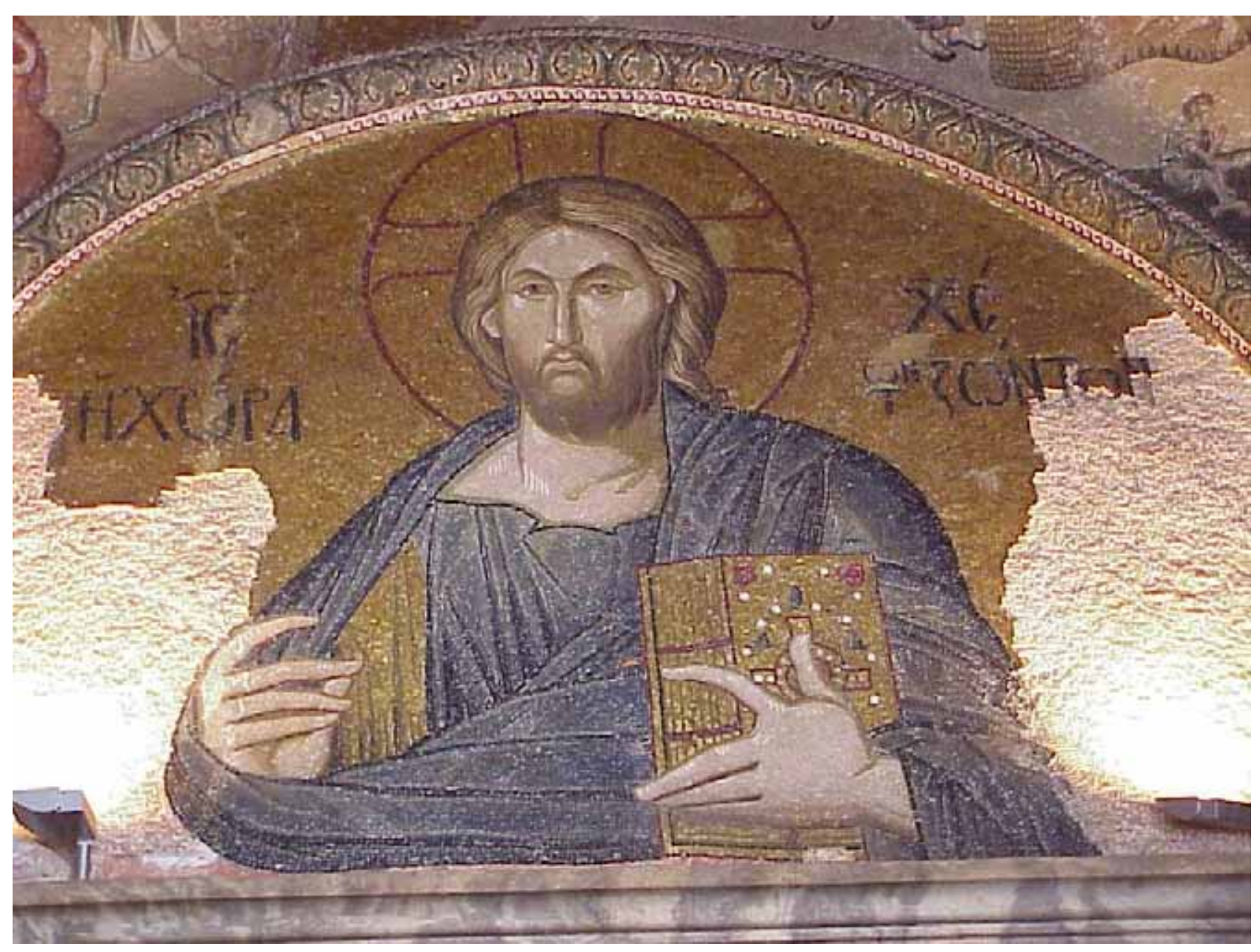

Figure 1. 


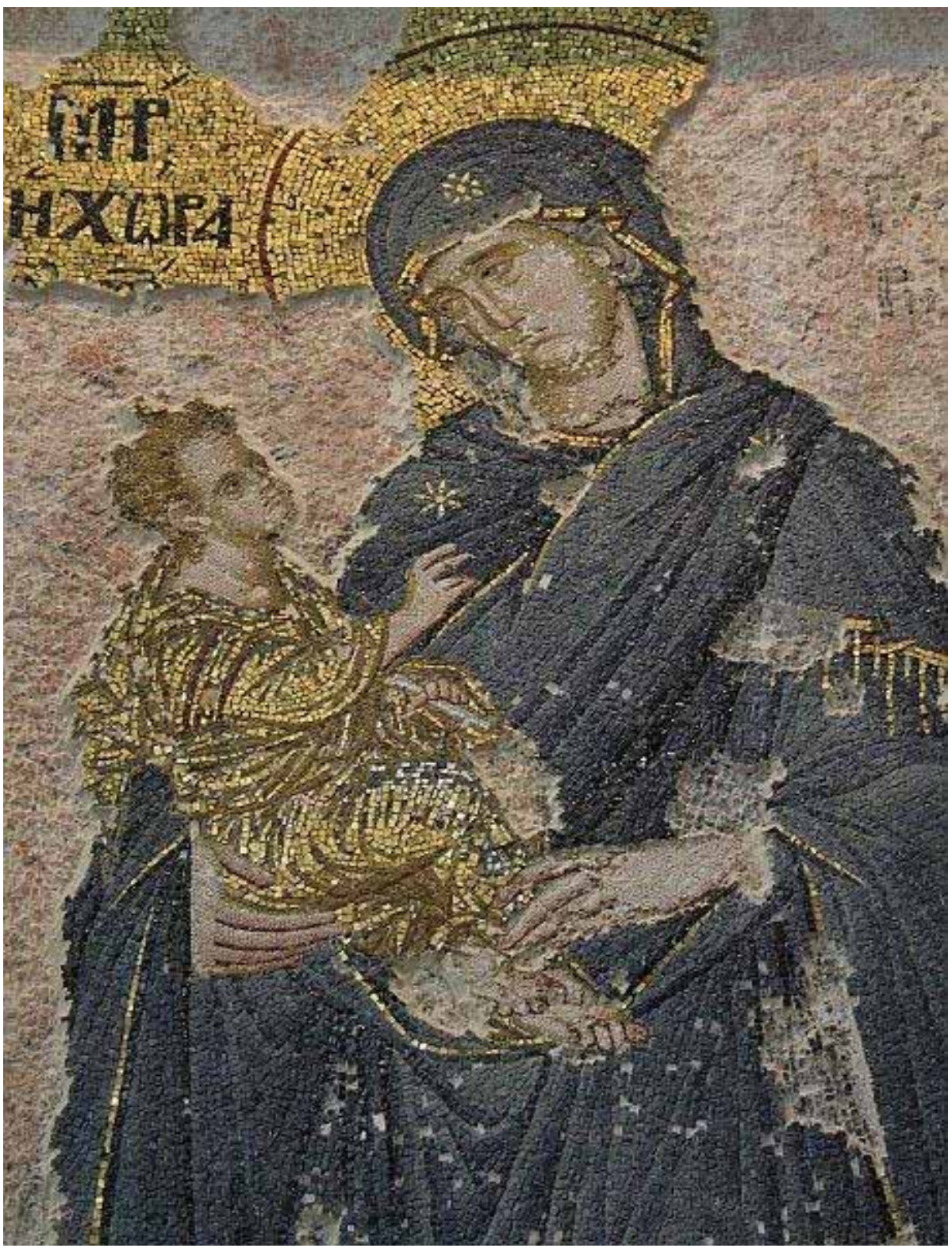

Figure 2. 


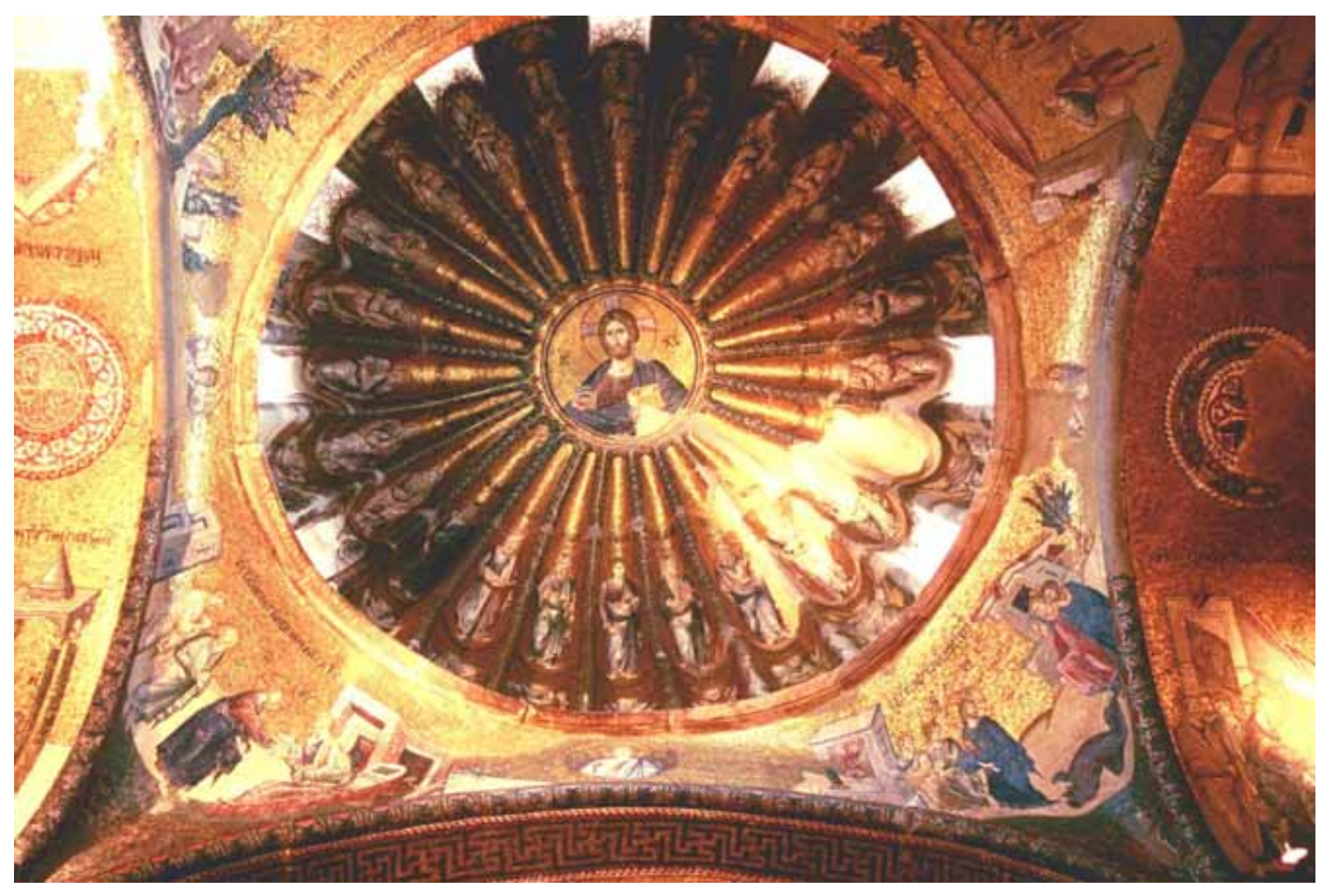

Figure 3. 


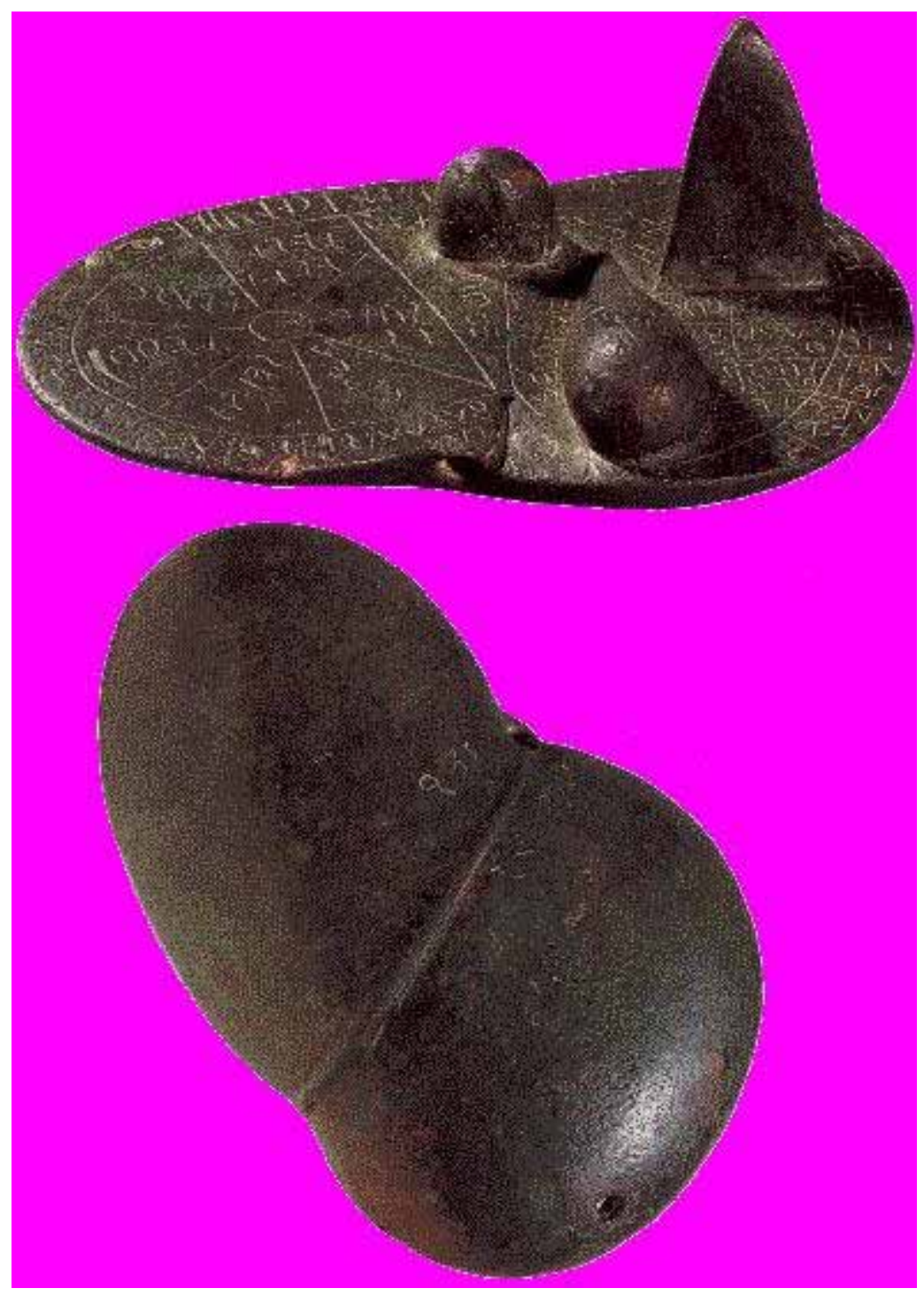

Figure 4. 


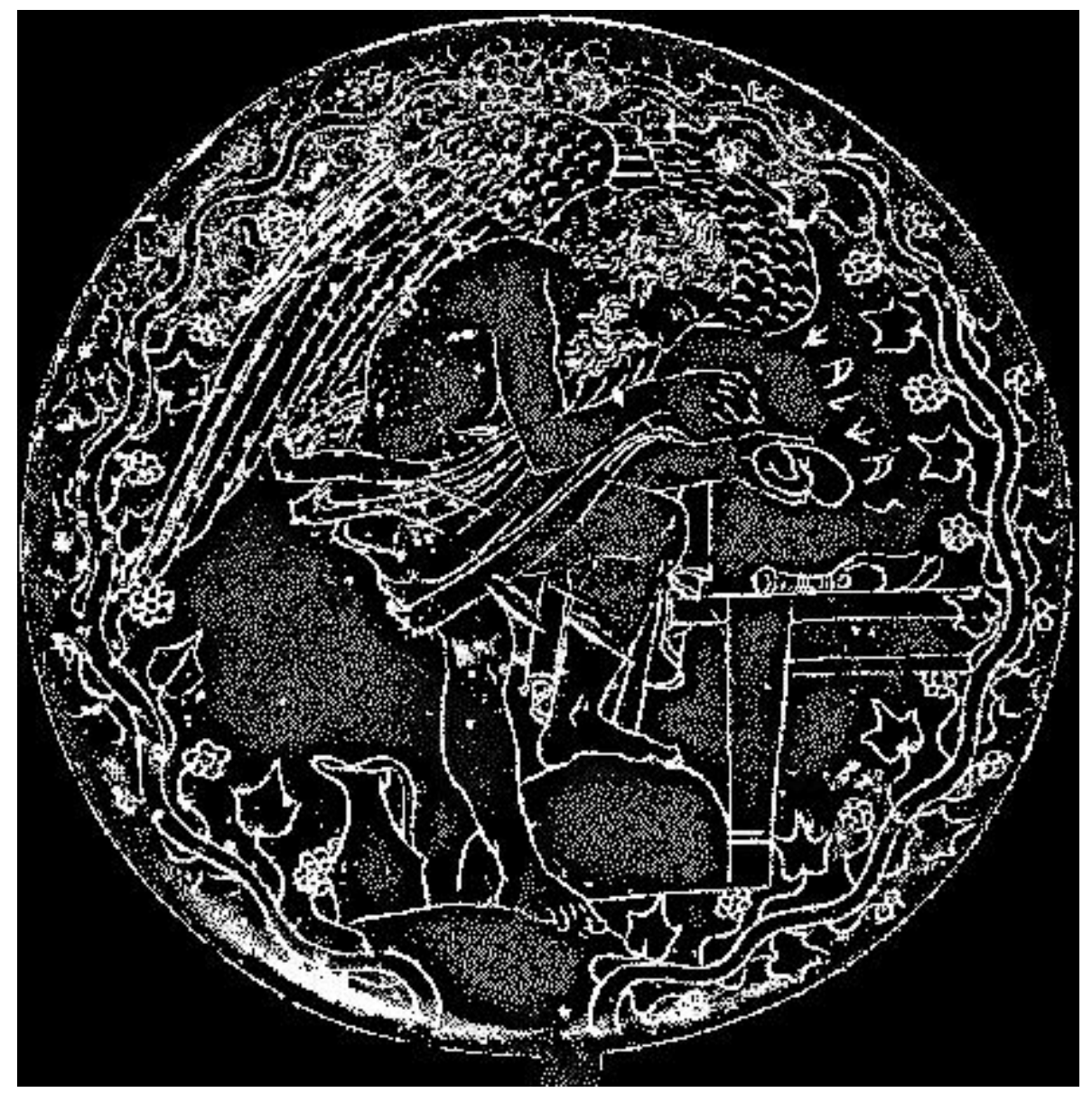

Figure 5. 


\title{
Perspective on Natural Gas Crisis between Russia and Ukraine
}

\author{
Chunyang Shi \\ Institute of World Economics, Liaoning Academy of Social Sciences \\ No. 86, Taishan Road, Shenyang 110031, Liaoning, China \\ Tel: 86-24-8872-6073 \\ E-mail: lena43@163.com, Chunyang7843@sina.com
}

\begin{abstract}
In 2009, the natural gas dispute between Russia and Ukraine was clothed with the name of "Natural gas crisis" and "Cold War" due to its long-time lasting and extensive spreading sphere. Under the circumstances when the financial crisis plagued the whole world, Russia and Ukraine suffered from the financial crisis, Ukraine was going to begin its Presidential election, and internal political struggle began to heat up, the natural gas dispute was attached extraordinary political and economic meanings. In view of the superficial natural gas price and debt struggle, we can find out that political and economic wrestle behind was the actual reason for outbreak of the natural gas crisis between the two countries. In this article, the author will try to make a deep analysis in different standpoints and strategic consideration of the relative parties of the natural gas crisis, namely, Russia, Ukraine, European countries and America.
\end{abstract}

Keywords: Russia, Ukraine, Natural gas crisis

After the "disagreement" of Russia and Ukraine in 2006, the natural gas dispute between these two countries came on again in 2009. However, this "disagreement" differed from that former one because of its long-time lasting and extensive spreading sphere. In November 2008, a dispute took place between Russia and Ukraine due to debt and gas supply price. On January 1, 2009, Russia completely broke off gas supply to Ukraine, and affected gas supply to several EU countries. Afterwards, with urgent mediation and several negotiations of EU, the two parties finally signed a 10 -year gas supply deal. Russia agreed to give a $20 \%$ discount to Ukraine on the basis of the price of gas supply to Europe, while Ukraine agreed to maintain the rate of gas transmission to Europe that passed through Ukraine in 2009 the same as that in 2008. From January 1, 2010, calculation of gas supply price and rate of transit gas transmission between Russia and Ukraine will be in total accordance with European pricing. In terms of gas supply fee settlement, the two parties will exclude an intermediary agency. So far, the natural gas crisis which has been lasting for approximately 20 days has finally come to a stop. Yet thinking caused thereby never stops. Why Russia and Ukraine fight for that at the cost of their economy and international image when the financial crisis plagues the entire world and these two countries suffers from the financial crisis? What's the standpoint and strategic consideration of the relative parties of the natural gas crisis, namely, Russia, Ukraine, European countries and America? In this article, the author will try to make a profound analysis.

\section{Political and economic consideration of Russia}

\subsection{Financial crisis behind the gas crisis}

Under double attack of financial crisis and steep fall of international oil price, the Russia economy that had been developed with a fast speed at one time began to "hard land", and all items of economic indices deteriorated day by day. Since the second half year of 2008, Ruble has been devaluated greatly. Compared with the historical high value of the exchange rate of 1 dollar to 23.4 ruble, the range of price drop of the exchange rate of ruble to dollar at present has 
exceeded $40 \%$. Originally, dependency of Russia economy on foreign capital has been high, together with flight of a large amount of capital triggered by financial crisis, the total amount of capital flight in 2008 was up to $\$ 130$ billion. Besides, foreign exchange reserves in Russia also shrank greatly, and it was estimated that foreign exchange reserves in 2009 might be reduced to $\$ 400$ billion. Simultaneously, Russian banks and enterprises was in high foreign debt, with a serious shortage of fluidity, so it was encountered with job displacement and a reduction in production. The GDP of Russia in January 2009 reduced by $2.4 \%$ over the same period of 2008, a negative economic growth had happened for two months, and meanwhile the population of unemployment had been on the increase. According the report issued by international rating agency, it was estimated that export of Russia in 2009 might shrink by $25 \%$, its GDP might be reduced by $2.2 \%$, its industry might slide down, its property market and stock market might be seriously frustrated, and the phenomenon of unemployment would get more serious. All this has been an actual portraiture of the current domestic situation in Russia. The Russian "economic train" stimulated by "oil dollar" has displayed a weak and tired condition of progress. Furthermore, Gazprom that has controlled the forces in the international energy market has also had a hard time. Since the attack of financial tsunami, Gazprom's market value of shares has reduced by 3/4, and its debt was up to 40 billion Euro. Profits of the enterprises have descended, in urgent need of investment. However, under the circumstance of current credit crisis, financing is quite difficult. Therefore, financial crisis has made both Russian Government and Gazprom strapped for cash. From this perspective, the direct reason for the "disagreement" of Russia is money.

\subsection{Fight for control power of energy geostrategy}

1.2.1 Control power of Ukrainian natural gas pipeline

Ukrainian natural gas pipeline is one of the largest transportation systems in Europe which is second only to that of Russia, and is an important hinge for connecting European major production regions and consumption regions of natural gas, so it has a strategic significance. At present, except for Yamal-Europe Pipeline, all natural gas pipelines from Russia to Europe pass Ukraine. Each year, Russia delivers to Europe approximately 120 billion cubic meters of natural gas through pipelines of Ukraine, which accounted for about $80 \%$ of the total amount of natural gas from Russia to Europe. Ukraine controls the key channels of natural gas exported from Russia to Europe, so it often threats Russia by increasing rate of gas transmission and even by "cutting gas", for which Russia has always been deeply concerned. As a matter of fact, as early as in 2002, Russia and Ukraine signed a deal for co-managing and developing their natural gas transportation system. However, rising to authority of Viktor Yushchenko made this project come to an untimely end. Control of Ukrainian natural gas pipeline has always been perplexing Russia for quite a long time. During the period of natural gas crisis, the President of Russia Putin and the President of Gazprom Miller respectively expressed that, Russia planned to research and take part in the privatized process of Ukrainian natural gas transportation system.

\subsubsection{Right to decide the price of energy}

In recent years, high price of international energy has brought a huge sum of wealth to Russia. Putin made an outright statement that the export of energy helped Russia rise. However, the role Russia has been playing is still a game participant, but not a rule maker. This determines its high dependency on other countries of Russian energy price and the great uncertainty. The financial crisis and frustrated oil price made Russia more desperate to participate in formulating rules of the energy market. On January 19, 2009, the final result of the natural gas deal between Russia and Ukraine enabled Russia to acquire the right to decide price of its natural gas, and also the right in terms of the rate of transit gas transmission. In addition, Russia shifted earlier the deadline of the transition period of pricing originally determined, which was in line with Russia's standpoint to adopt the market pricing as soon as possible. Without doubt, this has been a victory for Russia, and it can also be regarded as another effort made by Russia in recent years to improve its right to decide the international energy pricing.

\subsubsection{Control power of Post-Soviet space}

Since the "Orange revolution" in Ukraine in 2004, the progress of Ukraine to break away from Russia and to join in Europe has been quickened, which has caused strong response of Russia. Since 2008, the pro-western standpoint of Ukrainian leaders have been more definite. They volunteered to join in NATO, and supported Georgia during the Russia-Georgia Conflict and provided weapons to Georgia, which accumulated more rancor between Russia and Ukraine. Since Ukraine goes further from Russia, Russia threats and punishes Ukraine by means of "cutting off the 
natural gas supply". And Russia also warns other independent states of Commonwealth that have the same tendency that, if they continue to carry out the pro-western policy, and it they don't abide by the rule formulated by Russia in the Post-Soviet Space, then they won't hope for the "favor" of Russia. Since the Russia-Georgia Conflict, Russia has further regarded the Post-Soviet Space as the priority area for its imposing of any influence. With its increasingly strong national power, Russia gets back its confidence of Great Power, and the control power of Post-Soviet Space is a necessary choice for Russia to realize its geostrategic interests.

\section{Domestic political fight in Ukraine}

Financial crisis has seriously attacked Ukrainian economic system. The current Ukrainian inflation rate is up to $100 \%$, and its monetary exchange rate to the US dollar is also devaluated by half. Furthermore, Ukraine is faced with such difficulties of reduced industrial production, increased unemployment population, serious shortage of foreign exchange. As the originally second largest Economy in the entire Soviet Union, Ukraine was seriously short of farm products, and became one of the first countries to put forward application for assistance to IMF. In such an economic situation, it was without doubt that intensification of the natural gas dispute would add more difficulties to Ukrainian economy which had been originally difficult. Then, why did Ukraine challenge Russia, and "act rashly" against Russia? Political fight within Ukraine was the catalyst of the natural gas crisis, and both the President Viktor Yushchenko and the Prime Minister Tymoshenko intended to gain their political capital through this natural gas dispute. Yushchenko's persistence of enlarging the dispute was a speculative trial to get Ukraine to join in EU and NATO.

During the "Orange revolution", Ukraine was in a split condition, and the relation between the president and the prime minister deteriorated. Since September 2007 when the Tymoshenko alliance led by the Prime Minister Tymoshenko and the "Our Ukraine-People's Self-Defense" led by the president constituted the governing coalition, internal contradiction within the coalition got rapidly acute, and the two parties were diametrically opposite in terms of economic policy and foreign affairs. Influences of the forthcoming 2009 presidential election and the financial crisis on Ukraine became gradually manifest, and internal fight within Ukraine turned white hot. Under attack of the financial crisis, political and economic crisis of Ukraine was forced to approach its critical point. The financial crisis firstly attacked prestige of the President Yushchenko. If we say that favorability rating of Yushchenko during the "Orange revolution" surpassed 60\%, then the current rating is less than 5\%. Party of the Regions and Communist Party of Ukraine publicly expressed in the Parliament that they would impeach the President. However, Tymoshenko challenged authority of the President in virtue of his flexible internal and foreign policies. Domestic political fight within Ukraine would directly affect the problem of natural gas. During the natural gas dispute, internal political top leaders of Ukraine couldn't speak in one voice, because natural gas was regarded as the natural bargaining chip of political confrontation. Each group of Ukrainian regime intended to obtain their own economic interests, including transporting and supplying natural gas of Russia to Ukraine. With different economic interests, it was impossible to get a political consensus. As for Ukraine, natural gas was a potent political resource utilized by the President Viktor Yushchenko and the Prime Minister Tymoshenko. Both of them didn't want to give up this trump card during the political fight, and both wanted to win "popularity" of election through "disagreement". However, this "disagreement" obviously interrupted resolution of the natural gas dispute. The Russian President Putin and the Ukraine Prime Minister Tymoshenko signed a gas supply deal of $\$ 250 / 1000 \mathrm{cms}$ in October 2008, but immediately, the President Viktor Yushchenko interfered by proposing the requirement that the price of 1 thousand cubic meters of natural gas should not surpass $\$ 201$. In face of the crisis, each group in Ukraine sought to gain a score in terms of politics, which was even more urgent than resolution of the crisis per se. Besides, the extraordinary action of Ukraine to get close to Europe during this natural gas crisis was, on one hand, to inflict pressure upon Russia, and on the other hand, to add its negotiation weight in future negotiation with EU.

\section{Neutral standpoint of EU}

Different from the hard attitude of European reproval on abuse of energy weapons by Russia three years ago, EU tried to avoid attaching the "Business dispute" between Russia and Ukraine any political color, and refused repeatedly to be an intermediary and conciliator. However, with sudden escalation of the natural gas dispute on January 7, the natural gas transported to Europe by Russia through Ukraine was totally cut off, which caused 18 European countries to suffer from difficulties without gas. EU believed that, the incident had transferred from the bilateral trade dispute of Russia and Ukraine to a political issue of Europe, Russia and Ukraine, so EU had to change its indifferent attitude several days 
ago and was engaged in active conciliation between Russia and Ukraine. EU really had no choice from not intending to get involved to being enforced to get involved.

Pan-Europeanization of the natural gas issue between Russia and Ukraine caused all relative EU countries to be "hostage" of this crisis, and simultaneously hit the "soft rib" of EU energy once again. One fourth of EU's natural gas was imported from Russia, among which $80 \%$ was transported through Ukraine, so energy security of EU seemed fragile during this disturbance. After the natural gas dispute that took place 3 years ago, EU promised not to be subject to the natural gas dispute any more. EU had planned to add energy supply sources and transportation pipelines, and appealed to its member countries to increase their natural gas stock. However, within the 3 years, essential measures that EU achieved have been not enough. As a matter of fact, EU doesn't have many choices. EU is quite aware that, its energy dependency on Russia in the foreseeable future will not be weakened, but instead, will be further strengthened. Therefore, EU doesn't want to affect the essential relations between Russia and EU because of the issue of "gas cut". However, "gas cut" triggered the vital interests of EU to a great extent, so EU can't but see to this issue. Therefore, EU has no other choice but to select the conciliation of a difficult neutral route.

Perennial natural gas "controversy" between Russia and Ukraine caused great hardship to EU. In "Sueddeutsche Zeitung", German reported with no choice that the project of Russian natural gas pipeline was a typical dependency of Europe on Russia, and this was a "constructional mistake" for Europe. On January 12, Secretary of Energy in EU presided over an extraordinary session in Brussels, and assessed serious results of "disagreement" between Russia and Ukraine on EU member countries. He decided to realize diversification of energy sources within a long and middle term of period and to ensure energy security. However, before realization of the diversification by EU, it is EU that is in a passive position during the "natural gas war" between Russia and Ukraine.

\section{Geostrategic interests of US}

"Ukraine stands in the middle of the giant" --- there is no exaggeration to describe the important geostrategic status of Ukraine. Therefore, every action by Ukraine affects nerves of Russia and America. Although America didn't go to the foreground during this natural gas dispute, it seems that she arranged and directed this game behind the scenes.

On January 9, 2009 when the natural gas dispute between Russia and Ukraine was on its summit, America and Georgia signed a security, economic and cultural cooperation agreement. America pointed out that, she also signed a strategic cooperation agreement with Ukraine on December 14, 2008, which deepened cooperation of these two countries in terms of their response to a crisis and their defense and security for promoting security and stabilization. The choice of America to sign a strategic agreement with Georgia at that that and to point out the similarity of this agreement to that between America and Ukraine was rather meaningful. On one hand, America inflicted pressure upon Russia. On the other hand, she supported and encouraged Ukraine, which might explain the extraordinary "bravery" of Ukraine during this natural gas dispute. On January 14, the Russian "Izvestia" reported in its article "America controlling Ukrainian pipelines" that, the natural gas transportation system of Ukraine will soon have its new master, who comes from the other side of the Great Ocean. This journal mastered content of the strategic partnership chapter signed by Ukraine Minister of Foreign Affairs Огрызко Владимир Станиславович and US Secretary of State Rice in December last year. The chapter mentioned that, Washington would help with modernization of natural gas pipeline in Ukraine. America had neither mined natural gas in Europe, nor transported natural gas to European transits, then why did she sign a transit agreement? The current US Secretary of State Hilary pointed out "deep thinking and plan far ahead" of America on this issue. She said, "My team and I will try to persuade our European partners to sign a political agreement which is aimed at guaranteeing to construct Nabucco and other potential natural gas pipelines, so as to help Europe with its natural gas supply. Success of the strategy to construct Nabucco and other replaceable natural gas pipelines requires unremitting cooperation at the political level, including cooperation with America. The new Obama government will have a positive effect on European energy supply situation. Dependency of Europe on Russian energy will result in a political dependency, and we will help Europe get out of this dependency. Our enlargement of trade and investment in energy across the Caspian Sea is our priority consideration." Therefore, we can conclude intentions of US in its intervene in the natural gas dispute between Russia and Ukraine as follows: to support pro-western policy of Georgia and Ukraine, to weaken influences of Russia, to control energy across the Caspian Sea, and to further take control of EU.

Above all, during this "natural gas war" of Russia and Ukraine, the fact was that, Russia and Ukraine "had a contest" on 
the surface, Russia and America "wrestled" behind, and EU "suffered" indirectly. Although the natural gas deal of Russia and Ukraine signed on January 19 finally got the natural gas dispute resolved, still there exist some pendent issues, and factors underlying "disagreement" of Russia and Ukraine for the second time still exist. Underlying superficial debt and price fight, geopolitics fight and game playing behind are the genuine origin that triggers the natural gas dispute.

\section{References}

Ian Traynor. (2009). Энергетические битвы приводят к политическим заморозкам в отношениях Москвы и Киева. [Online] Available: http://www.inosmi.ru/stories/06/01/05/3473/246569.html (January 12, 2009).

Роман Федосеев. (2009). Женщины жмут на газ” Дабы снизить энергозависимость ЕС от России, госдепартамент США будет активно развивать проект Nabucco. [Online] Available: http://www.vz.ru/politics/2009/1/15/246744.html.

Yu, Hongjian. (2009). Gas Resupply of Russia to Ukraine and Europe. People's Daily, $3^{\text {rd }}$ edition, January 21. 


\title{
Voice of Turkish Customer: Importance of Expectations and Level of Satisfaction at Airport Facilities
}

\author{
Özlem Atalık \\ School of Civil Aviation, Anadolu University \\ İki Eylül Kampüsü, Eskişehir, Turkey \\ Tel: 90-222-322-2059Ｅ-mail: oatalik@anadolu.edu.tr
}

\begin{abstract}
Delivering high-quality service to passengers is essential for airports survival. Service quality conditions influences an airports competitive advantage by profitability. To deliver better service to passengers, airports managers needed to understand passengers' need and expectations. Passenger expectations are a key performance indicator for the operation of an airport. Passengers evaluated airports different factors: getting to the terminal; leaving the airport; check-in process; baggage claim, security check, gate areas, concessions, and immigration/customs control etc.

The objectives of this study understanding importance of customer expectations and level of satisfaction perceived by customers concerning the capabilities, facilities and services of airport. Primary data were collected from passengers departing Ataturk airport in Istanbul which is the biggest airport in Turkey
\end{abstract}

Keywords: Customer expectations, Perceived satisfaction, Airport facilities, Turkey

\section{Introduction}

Understanding, creating, communicating, and delivering customer value and satisfaction are at the very heart of modern marketing practice. The customer, rather than marketing, is at the center of modern business philosophy, and customer service satisfaction is the primary aim. In service industries such as the airline and airport industry, the distinctive features of services require that managers understand customer needs and expectations, and keep promises (Zeithaml and Bitner, 2000). Understanding travelers' airport choice behaviors is an important topic in the aviation industry. Airport managers need to know how travelers make airport-choices, because each airport must constantly generate adequate passenger traffic (i.e., attract travelers) to justify its existence (Suzuki, 2007)

The airport business within the air transport industry. Air transport business is a rather complex macro industry. Within the industry, a mass of activities are being undertaken by a complementary and combined network of actors: passenger and cargo airlines, integrators, airport authorities, handling agents, in-flight catering firms, General Sales Agents, car rentals, air brokers, hardware providers like aircraft manufacturers and air terminal building firms, tour operators and travel agents, all of them striving to satisfy, at least partly, end demand needs. (Jarach, 2001)

Marketing did not play a significant role in the management of airports until the 1980s, prior to which time the airport was commonly viewed as a free public service or utility provided by governmental or quasi-governmental entities. Deregulation of the airlines and other sectors of the air transport industry, however, motivated airports to begin competing for airline routing. Marketing was first introduced at airports that sought to either enlarge or protect their airline customer base. As air travelers became more sophisticated and demanding, airports came to believe that they could influence airline routing decisions by a "pull" strategy of directing marketing efforts to end users, offering enhanced services or the promise of exceptional levels of customer satisfaction. As a result, by the 1990s, many airports 
were concentrating greater attention and investments on a wide array of marketing activities in an effort to survive in an increasingly competitive marketplace. Like many service industries, the airport industry turned to service quality as a strategy for achieving competitive advantage (Lee-Mortimer, 1993, Fodness, Murray, 2007)

Air passengers' expectations have grown considerably in recent years especially in regard to quality of service. Furthermore, as airports are working more and more in a competitive environment, quality criteria have been widely. (www.transport.ie) Today's air travelers have meaningful choices among airports and there is an increasing urgency among airport marketers to differentiate themselves by meeting the needs of customers better than the competition. While passengers' perception of airport service quality is only one of several variables that contribute to overall airport attractiveness, it is nevertheless an important variable because of the increasing importance of a customer orientation to competitive advantage in this industry (Fodness, Murray, 2007)

Aviation trade publications and airport press releases provide evidence that managers in the airport industry clearly understand the importance of their customers' perceptions of service quality (Bomenblit, 2002). Academic and industry researchers regularly measure passenger perceptions of airport services quality to benchmark performance metrics directly from the "voice" of the customer (Chen, 2002), to identify opportunities for service improvement (Yeh and Kuo, 2002) and to avoid losing valuable passenger traffic (Rhoades et al., 2000). In addition, airport marketer's research passenger needs and wants for the purposes of enhancing non-aviation related revenues from restaurant and retail offerings (Danyliew, Cohen, 1997)

\section{The Importance of Measuring the Performance of Airports}

Airport managers need to have information to enable them to monitor performance and to identify areas that are performing well and those that are not. Once performance is known, management can examine the underlying processes taking place so that appropriate corrective action can be proposed. (Park, 1999)

The nature of the expectations underlying airport service perceptions is unclear. Unlike the more widely accepted gap-theory model for measuring service quality (i.e. subtracting a customer's perceived level of service received from what was expected), both academic and commercial airport researchers are more likely to measure service quality by establishing and monitoring service performance measures which may or may not be informed by direct customer input (Yeh, Kuo, 2002, Fodness, Murray, 2007)

Information on an airport and its related systems can be generated from its own operational and technical characteristics, as well as from traffic flow and demand pattern characteristics. The collection of information on passengers is often conducted by means of airport passenger surveys. Various survey methods have been used in airports around the world. Generally, airport survey methods or techniques are divided into direct and indirect methods. Direct methods for collecting data can be directly obtained at the airports. These survey techniques start and end at the airport. Direct data collection methods include direct observation, photographic techniques, monitoring, tailing, time-stamping, questionnaires, and interviews. Indirect methods are used when required data cannot be directly obtained from passengers at the airport. Mail back questionnaires, telephone questionnaires, statistics and documented data are options. (Park, 1999)

Service measures based on the subjective perception of service quality by airport users are collected through surveys in which respondents are asked to grade their experience on a 5-point scale. Common measures included overall customer satisfaction at the airport, signage/user friendliness of terminal, cleanliness of terminal, cleanliness of restrooms, check-in satisfaction, catering overall satisfaction, value for money in the shops, baggage delivery overall satisfaction, availability of baggage trolleys, and overall standards of car park facilities. Subjective criteria are used together with objective measures to develop a picture of service performance. Objective measures recorded at more than half of the airports surveyed included response time to customer comment cards, availability of trolleys (percentage of satisfied passengers), check-in waiting time, security check waiting time, baggage delivery time, taxi waiting time, and punctuality/ delayed flight departures attributable to the airport (percentage over a certain time/total departing flights) (Humphreys, et al., 2002)

In addition to business measures, managers, regulators, and government bodies need to measure the service performance of airports. Service measures are used to assess the day-to-day service quality delivered by the different parts of an airport 
to its users. Short- and long-term summaries of this information provide a vital input to airport management. Service measures are particularly useful for identifying operational problems. (Fodness, Murray, 2007)

\section{Research}

Objective of the Study: The aim of this study is to determine the order of importance of customer expectations and level of satisfaction perceived by customers concerning the capabilities, facilities and services of Istanbul Atatürk Airport.

Limitations of the secondly Research: The research is limited by the questionnaire answered between the $26^{\text {th }}$ and $30^{\text {st }}$ of April, 2008 by 140 passengers. Data were collected from passengers departing Istanbul Ataturk Airport. The international terminal of the Istanbul Ataturk Airport was chosen as the main data-collection point which is one of the largest international airport in Turkey. And it's located at the crossroads of Europe and Asia.

Research Method: Face-to-face interview is the method for the research.

Collection of the Research Data: A pilot work has been done with 22 passengers to learn about how good the questions in the questionnaire form serve for the objective of the research. According to answers to those questions, some modifications have been done in the questions Then, the research questions were asked on between the 26 and 30 of April, 2008 by 140 usable questionnaires were gained in the research and Microsoft Office Excel and 13, 0 (Statistics Pack for Social Sciences) were used in the analysis.

Reliability Analysis of the Research: It is possible to say that the research is reliable as a whole, according to the coefficient of reliability $\alpha=0.8811$.

\section{Research Findings}

(Insert Table 1 Here)

As can be seen Table 1, 78, 6 of Turkish passengers and 21, $4 \%$ foreign passengers and 57, $1 \%$ of male and 42, $9 \%$ of them are female passengers. When the distribution of the subjects according to their age range is analyzed it can be seen that $21.4 \%$ of them are aged between $22-29,50.7 \%$ of them are aged between 30-37, 12,9\% of them are aged between $38-45,7,9 \%$ of them are aged between $46-53$ and $\% 7.1$ of them are aged 54 or more than it. Consequently it is seen that passenger intensify between " $30-37$ ".

When the distribution of the members related to their education background is examined, it can be seen that $61.5 \%$ of the members are university graduates, $10,7 \%$ of them are master's degree graduates and $2.1 \%$ of them are doctor's degree graduates. When the proportion of the members who are graduates and postgraduates is analyzed in terms of the general sum a high proportion has been occurred as $74.3 \%$.

When the monthly incomes of the members are examined, it has been seen that $37,8 \%$ of them have monthly income as $1000-2000,33,6 \%$ of them have monthly income as $2001-3000,6,4 \%$ of them have monthly income as $3001-4000,3,6 \%$ of them have monthly income as $4001-5000,18,8 \%$ of them have monthly income as 5001- more than it.

(Insert Table 2 Here)

As can be seen Table 2 regarding passengers' frequency of using the Istanbul Atatürk Airport, it can be seen that $68,3 \%$ of passengers have flown 1-3 times, 28,6\% 4-6 times, 1,4\% 7-9 times and 1,4\% 10-13 times over the past year

(Insert Table 3 Here)

As can be seen in Table 3, customers find a vast majority of airport capabilities and facilities "important" while they regard the variety and number of cafes and restaurants, telephone and fax services, shopping facilities within the terminal, duty-free options, lounges of the cooperative banks as "neither important nor unimportant".

Table 3 also shows satisfaction level perceived by customers about the relevant capabilities and facilities. With regard to this dimension, it is clear that customers are satisfied with terminal size and cleanliness, toilet facilities, duty-free options, telephone and fax services, variety and number of products in duty-free. It is also noticeable that some of these capabilities and facilities mentioned are among those considered by customers as "neither important nor unimportant." On the other hand, some capabilities and facilities regarded by customers as "important" but to be on a low satisfaction level are also shown in Table 3. Among these capabilities and facilities are transportation to the terminal, parking lot capabilities and services, walking area, announcements, direction and signage, flight information screens, airport information services, 
behavior of check-in attendant, behavior of security personnel, choice of bars and cafes / food and drink prices, internet / Wi-Fi availability, smoking lounges / segregation, check-in waiting time, waiting duration for security check, shopping facilities, behavior of the personnel in duty-free shops, baggage claim speed, and baggage trolley availability.

However, although transportation to the terminal, announcements, choice of bars and cafes / food and drink prices, internet / Wi-Fi availability, smoking lounges / segregation, check-in waiting time, waiting duration for security check, and baggage claim speed are regarded by customers as "very important," it is clear that they are considered to be "not satisfactory." In other words, customers are not satisfied with these capabilities and facilities which they regard as important.

\section{Conclusions}

Airports populations are larger than most country. Their business activities can contribute billions of dollars to the economy. Many international airports show high growth number of passengers. This growth continuously challenges the quality experience of passengers at airport terminals. Customer satisfactions have to a primary goal of all airports. If an airport cannot attend to all services efficiently, airport satisfaction will be low and passengers' perception of the airport facilities becomes negative. For passengers, the primary goal is a quick, avoiding crowded check-in areas and long check-in queues not to mention slow security screening, and inefficient boarding processes. At this stage, passenger satisfaction depends to a large extent on how quickly and easily they can get their boarding passes, how simple it was to check in baggage, and how much control they had over the process.

Poor quality airport services can influence operations all the way down the line, affecting airports, airlines and passengers alike. Today, organizations offering airport services are challenged to achieve a balance between quality, service levels and costs for a number of reasons. However, airports can increase customer satisfaction, provide high levels of reliability and meet the quality standards expected in the industry by getting complete control over their entire airport services.

The prime objectives of many airports have to maximize customer satisfaction by aiming for high service levels. Currently, however, this concept is necessary to enable cross comparisons of design or physical standards and operational standards affecting passenger perceptions. Thus, airport authorities and airport managers should be able to develop updated operational standards based on passenger perceptions to provide more comprehensive service levels to maximize their satisfaction.

\section{References}

Airport voluntary commitment on air passenger service. [Online] Available: http://www.transport.ie/upload/general/2697.pdf, (January 12, 2009)

Bomenblit, A. (2002). Hong Kong International Tops Study. Business Travel News, October, 19, 6.

Chen, H-L. (2002). Benchmarking and Quality Improvement: A Quality Benchmarking Deployment Approach. International Journal of Quality \& Reliability Management, 19, 6, 757-773.

Danyliew, N.Q., Cohen, W. (1997). Airports Take off. US News and World Report, 21, 57-9.

Fodness D., Murray B. (2007). Passengers' Expectations Of Airport Service Quality. Journal of Services Marketing, 21, 7, 492-506.

Humphreys I., Francis G., Fry J. (2002). Performance Measurement in Airports: A Critical International Comparison. Public Works Management \& Policy, 6, 4, 264-275.

Jarach, D. (2001). The Evolution Of Airport Management Practices: Towards A Multi-Point, Multi-Service, Marketing-Driven Firm. Journal of Air Transport Management, 7, 2, 119-125.

Lee-Mortimer, A. (1993). Customer Focus Takes off. The TQM Magazine, 5, 37-41.

Park, Y. (1999). A Methodology for Establishing Operational Standards of Airport Passenger Terminals. Journal of Air Transport Management, 5, 73-80.

Rhoades, D.L., Waguespack, B. Jr., Young, S. (2000). Developing a Quality Index for US Airports. Managing Service Quality, 10, 4, 257. 
Suzuki, Y. (2007). Modeling and Testing The "Two-Step" Decision Process of Travelers in Airport and Airline Choices.

Transportation Research Part E: Logistics and Transportation Review, 43, 1, 1-20

Yeh, C-H., Kuo, Y-L. (2003). Evaluating Passenger Services of Asia-Pacific International Airports. Transportation Research Part E, 39, 1, 35-48.

Zeithaml V.A., Bitner M.J. (2000). Services Marketing: Integrating Customer Focus Across the Firm. McGraw-Hill, Madison . 
Table 1. Demographics

\begin{tabular}{|c|c|c|}
\hline Nationality & Frequency & Percent \\
\hline Turkish & 110 & $\% 78,6$ \\
\hline Other & 30 & $\% 21,4$ \\
\hline Sexual & Frequency & Percent \\
\hline Man & 80 & $\% 57,1$ \\
\hline Women & 60 & $\% 42.9$ \\
\hline Age & Frequency & Percent \\
\hline $22-29$ & 30 & $\% 21,4$ \\
\hline $30-37$ & 71 & $\% 50,7$ \\
\hline $38-45$ & 18 & $\% 12,9$ \\
\hline $46-53$ & 11 & $\% 7,9$ \\
\hline 54 and more & 10 & $\% 7.1$ \\
\hline Education & Frequency & Percent \\
\hline Primary school & 21 & $\% 15,0$ \\
\hline High school & 15 & $\% 10,7$ \\
\hline University & 86 & $\% 61,5$ \\
\hline Master & 15 & $\% 10,7$ \\
\hline Doctorate & 3 & $\% 2,1$ \\
\hline Monthly income(TL-\$) & Frequency & Percent \\
\hline $1000-2000$ & 53 & $\% 37,8$ \\
\hline $2001-3000$ & 47 & $\% 33,6$ \\
\hline $3001-4000$ & 9 & $\% 6,4$ \\
\hline $4001-5000$ & 5 & $\% 3.6$ \\
\hline 5001 and more & 26 & $\% 18,6$ \\
\hline Total & 140 & 100,0 \\
\hline
\end{tabular}

Table 2. Regarding passengers' frequency of using the Istanbul Atatürk Airport

\begin{tabular}{|l|l|l|}
\hline $\begin{array}{l}\text { Regarding passengers' frequency } \\
\text { of using the Atatürk Airport }\end{array}$ & Frequency & Percent \\
\hline $1-3$ times & 96 & 68,6 \\
\hline $4-6$ times & 40 & 28,6 \\
\hline $7-9$ times & 2 & 1,4 \\
\hline $10-13$ times & 2 & 1,4 \\
\hline Total & $\mathbf{1 4 0}$ & $\mathbf{1 0 0 , 0}$ \\
\hline
\end{tabular}


Table 3. Comparison of the Importance and Perceived Satisfaction Levels for the customers on the airport capabilities and facilities

\begin{tabular}{|c|c|c|}
\hline Airport Capabilities and Facilities & Mean Expectation & Mean Satisfaction \\
\hline Transportation to the terminal & 4,4929 & 2,6143 \\
\hline Parking lot capabilities and services & 4,1429 & 3,8429 \\
\hline Terminal size & 4,1357 & 4,0000 \\
\hline Terminal cleanliness & 4,6071 & 4,2000 \\
\hline Toilet facilities & 4,5857 & 4,1357 \\
\hline Walking area & 4,4857 & 3,8857 \\
\hline Directions \& signage & 4,4571 & 3,6286 \\
\hline Flight Information screens & 4,4643 & 3,5929 \\
\hline Announcements & 4,4643 & 2,5857 \\
\hline Variety and number of cafes and restaurants & 3,8714 & 3,6714 \\
\hline Choice of bars \& cafes / food \& drink prices & 4,1786 & 2,5143 \\
\hline Telephone / Fax services & 3,2929 & 3,1786 \\
\hline ATM Cash machines & 4,0786 & 3,5429 \\
\hline Internet/wifi availability & 3,4643 & 2,6857 \\
\hline Smoking lounges / segregation & 3,2286 & 2,9786 \\
\hline Airport information services & 4,4357 & 3,9643 \\
\hline Check-in waiting time & 4,7429 & 2,3143 \\
\hline Behavior of check-in attendant & 4,5429 & 3,8500 \\
\hline Waiting duration for security check & 4,7286 & 2,1000 \\
\hline Behavior of security personnel & 4,4929 & 3,8214 \\
\hline Shopping facilities within the terminal & 3,5286 & 3,4643 \\
\hline Behavior of duty-free attendant & 4,0500 & 3,7857 \\
\hline Duty-free options & 3,2500 & 3,4500 \\
\hline Variety and number of products in duty-free & 3,3714 & 3,4500 \\
\hline Lounges of the cooperative banks & 3,0643 & 3,1357 \\
\hline Baggage claim speed & 4,8143 & 2,4357 \\
\hline Baggage trolley availability & 4,6286 & 4,0071 \\
\hline
\end{tabular}


A journal archived in Library and Archives Canada

A journal indexed in Canadiana (The National Bibliography)

A journal indexed in AMICUS

A journal included in Google Scholar

A peer-reviewed journal in European studies

\section{Review of European Studies}

\section{Semiannual}

Publisher Canadian Center of Science and Education

Address 4915 Bathurst St. Unit\#209-309, Toronto, ON. M2R 1 X9

Telephone 1-416-208-4027

Fax 1-416-208-4028

E-mail res@ccsenet.org

Website www.ccsenet.org

Printer William Printing Inc.

Price CAD.S 20.00 